UNIVERSIDADE DE SÃO PAULO

FACULDADE DE FILOSOFIA, LETRAS E CIÊNCIAS HUMANAS

DEPARTAMENTO DE GEOGRAFIA

PROGRAMA DE PÓS-GRADUAÇÃO EM GEOGRAFIA HUMANA

Danilo Pereira Sato

Territórios e Conflitos na Área de Proteção Ambiental da

Várzea do Rio Tietê

VERSÃO CORRIGIDA

São Paulo

2018 


\title{
Territórios e Conflitos na Área de Proteção Ambiental da Várzea do Rio Tietê
}

\author{
Versão Corrigida
}

Danilo Pereira Sato

Dissertação apresentada ao Programa de Pós-Graduação em Geografia Humana do Departamento de Geografia da Faculdade de Filosofia, Letras e Ciências Humanas da Universidade de São Paulo para obtenção do título de Mestre em Ciências.

Área de Concentração: Geografia Humana

Orientadora: Prof ${ }^{\mathrm{a}}$. Dra. Neli Aparecida de Mello-Théry

De acordo:

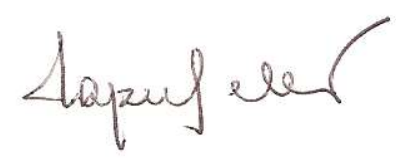

Neli Aparecida de Mello-Théry

São Paulo 
Autorizo a reprodução e divulgação total ou parcial deste trabalho, por qualquer meio convencional ou eletrônico, para fins de estudo e pesquisa, desde que citada a fonte.

Catalogação na Publicação

Serviço de Biblioteca e Documentação

Faculdade de Filosofia, Letras e Ciências Humanas da Universidade de São Paulo

S253to, Danilo Pereira
Territórios e Conflitos na Área de Proteção
Ambiental da Várzea do Rio Tietê / Danilo Pereira
Sato ; orientadora Neli Aparecida de Mello-Théry. -
São Paulo, 2018.
154 f.
Dissertação (Mestrado) - Faculdade de Filosofia,
Letras e Ciências Humanas da Universidade de São
Paulo. Departamento de Geografia. Área de
concentração: Geografia Humana.
l. Território. 2. Geografia Política. 3. Políticas
Púbicas. 4. Área de Proteção Ambiental. 5.
Governança. I. Mello-Théry, Neli Aparecida de,
orient. II. Título.


SATO, D. P. Territórios e Conflitos na Área de Proteção Ambiental da Várzea do Rio Tietê. 2018. 150 f. Dissertação (Mestrado em Geografia Humana) - Faculdade de Filosofia, Letras e Ciências Humanas, Universidade de São Paulo, 2018.

Aprovado em:

\section{Banca Examinadora}

Prof. Dr.:

Instituição:

Julgamento:

Prof. Dr.:

Instituição:

Julgamento:

Prof. Dr.:

Instituição:

Julgamento: 


\section{Agradecimentos}

São inúmeras as pessoas a serem agradecidas, mas começo com a minha orientadora, Neli Aparecida de Mello-Théry, pela orientação e paciência.

Agradeço à Aretha de Oliveira Araujo, sem a qual não teria sido possível me dedicar à pesquisa, por dividir as tarefas diárias.

Agradeço à minha mãe, Eliana Paschoalito Pereira, por me apoiar e incentivar nesta trajetória. Agradeço a Lilian Margarete de Oliveira e a Agnaldo Luis Araujo, por terem sidos verdadeiros pais, permitindo que eu me dedicasse à pesquisa. Agradeço também a Agnes de Oliveira Araujo.

Agradeço à Regina Lemos Nery, que me deu um apoio muito grande durante esse período do mestrado.

Ao CNPq, pela bolsa de mestrado concedida para poder priorizar as atividades do mestrado.

Agradeço ao prof. Andrea Cavicchioli, pelas primeiras orientações na graduação e por me incluir no projeto do Plano de Manejo da APA da Várzea do Rio Tietê.

Aos amigos do grupo de estudos do LERGEO: Simone de Affonso da Silva, Mariana Macêdo, Savanna Ramos, Mateus Sampaio, Ricardo Campos Júnior, Paulo Inácio, Gabriela Ribeiro e Melissa Steda, que me ajudaram pelos caminhos da geografia.

Aos amigos do mesmo grupo pesquisa e orientação, que contribuíram na minha pesquisa, Ravi Orsini, Clara Jacq, Júlia Affonso, Juliana Delgado, Juliana Colonna, Paulo Curi, Suzana Lourenço, Luciana Riça Mourão Borges e Paulo Cunha.

Às contribuições das professoras Cleide Rodrigues e Rita de Cássia Ariza da Cruz, na qualificação. Pelas contribuições na defesa, agradeço a pesquisadora Heloisa Tozato e aos professores Ricardo Palamar e Alessandro Soares da Silva.

Agradeço aos demais amigos que fizeram parte do SEPEGE: Caio Alves, Carolina Gabriel de Paula, Felipe Lopes, Ivan Martineli, Daniel Vasconcelos e Lucas Rocha.

Agradeço também ao professor Renato Cymbalista, ao Bernardo Loureiro, a Thaís Chang Waldman, a Suênia Almeida pelos desafios propostos que contribuíram para o meu amadurecimento na pesquisa. Agradeço também ao grupo Geografia Política Meio Ambiente pelas reflexões e discussões.

Agradeço as leituras e críticas da Simone Affonso da Silva, Lígia Pinheiro, Aline Shirazi Conte, Maíra Crístina de Oliveira Silva e Priscila Almeida.

Outras pessoas foram imprescindíveis para essa pesquisa, as quais agradeço. 


\section{Resumo}

SATO, D. P. Territórios e Conflitos na Área de Proteção Ambiental da Várzea do Rio Tietê. 2018. 150 f. Dissertação (Mestrado em Geografia Humana) - Faculdade de Filosofia, Letras e Ciências Humanas, Universidade de São Paulo, 2018.

A Área de Proteção Ambiental (APA) da Várzea do Rio Tietê é uma Unidade de Conservação estadual de Uso Sustentável localizada na Região Metropolitana de São Paulo (RMSP). A APA foi criada em 1987, em razão dos crescentes problemas com as inundações, para conservar as planícies de inundação do rio Tietê na RMSP. Entretanto, tem apresentado uma série de dificuldades para o seu funcionamento, desde inatividade e falta de conselho gestor nos anos 1990, até a adulteração do Plano de Manejo mais recentemente. Simultaneamente, no território da APA tem-se desenvolvido e sido propostas uma série de planos, programas e projetos de outras instituições estaduais, que conflitam com os seus objetivos. A presente pesquisa tem como objetivo entender os processos relativos à APA, que é pautada por um planejamento e zoneamento ambiental que se relaciona com planos, programas e projetos de outras instituições estaduais, que incidem no mesmo território. A pesquisa se baseia em uma análise a partir conceito de território e da contribuição das políticas públicas e da governança. A partir de levantamento documental, da observação participante e da análise espacial, são analisadas e comparadas as sobreposições territoriais e temporais dos planejamentos e dos projetos propostos, assim como suas articulações institucionais e espaços de participação.

Palavras-chave: Território. Geografia Política. Políticas Públicas. Área de Proteção Ambiental. Governança. 


\begin{abstract}
SATO, D. P. Territories and conflicts in the Environmental Protection Area of the Floodplain of the Tietê's River. 2018. 150 f. Dissertação (Mestrado em Geografia Humana) - Faculdade de Filosofia, Letras e Ciências Humanas, Universidade de São Paulo, 2018.

The Environmental Protection Area (EPA) of the Floodplain of Tietê's River is a state Conservation Unit of Sustainable Use located in Metropolitan Region of São Paulo (MRSP). The EPA was created in 1987 with the objective to reduce the growing flooding problems and protect the floodplain of Tietê's River in the MRSP. However, it has faced many difficulties to function, from inactivity to absence of the manager council in the 1990s and to the recent adulteration of the Management Plan. Simultaneously it has been developed and proposed a series of plans, programs and projects by the other state institutions that conflict with EPA objectives in its territory. The current research objective is to comprehend how the EPA process, which are guided by an environmental planning and zoning, relates with the other state institutions plans, programs and projects that are being implemented in the same territory. The research is based in an analysis through the concept of territory, the contribution of the field of public policies and governance. Starting from documents research, participant observation and spatial analysis the other plans and projects are compared in a temporal and territorial superposition as well as the institutional relations and the participation spaces.
\end{abstract}

Key-words: Territory. Political Geography. Public Policies. Environmental Protection Area. Governance 


\section{Lista de Figuras}

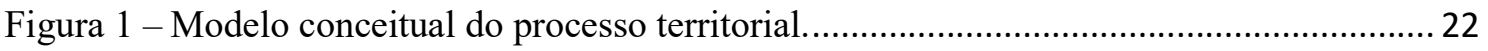

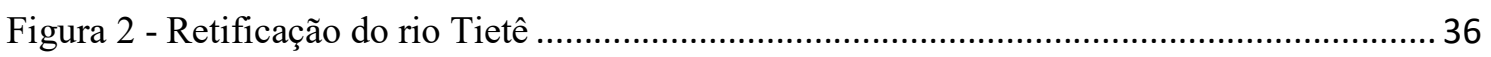

Figura 3 - Mapa da expansão urbana e os rios urbanos........................................................... 40

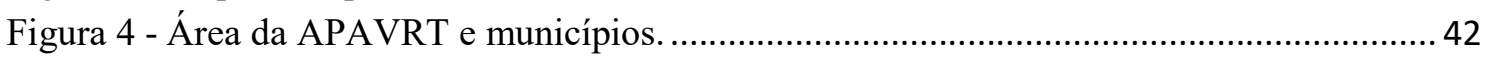

Figura 5 - Trechos de inundação com relação à APAVRT e a área urbanizada. ........................... 44

Figura 6 - Mapa do Zoneamento vigente da APA da Várzea do Rio Tietê................................... 45

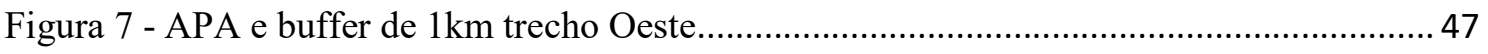

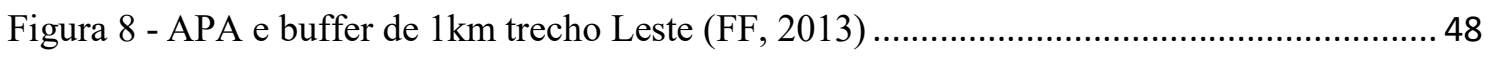

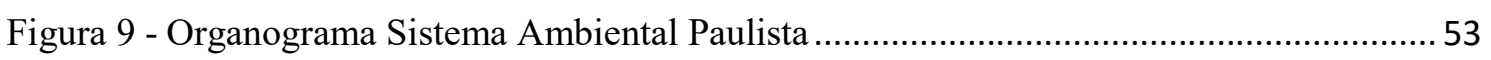

Figura 10 - Esquema da evolução das linhas incorporadas pela CPTM.................................... 59

Figura 11 - Esquema cronológico das políticas públicas que se sobrepõem com as respectivas

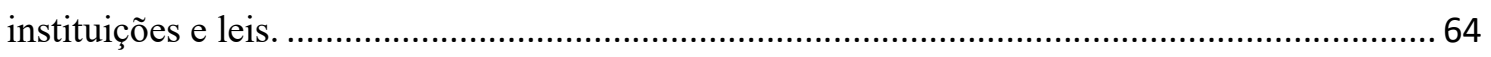

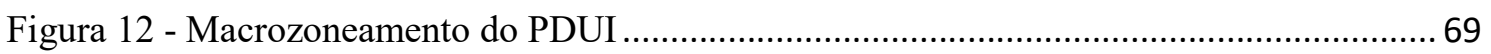

Figura 13 - Esquema da expansão da rede coletora de esgoto na RMSP ..................................... 72

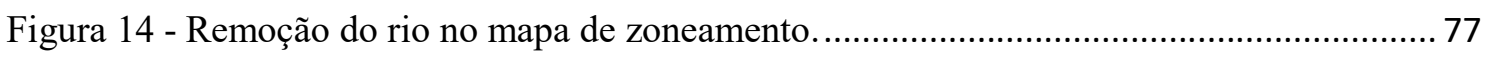

Figura 15 - Mapa das áreas identificadas pelo MPSP como adulteradas ....................................... 78

Figura 16 - Mapa das áreas identificadas pelo MPSP como adulteradas ..................................... 79

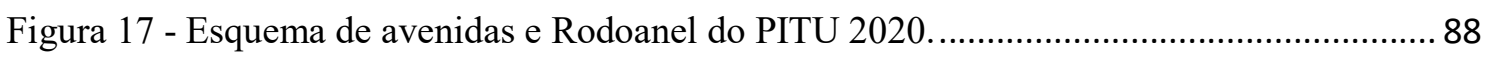

Figura 18 -Entorno do caminho de serviço na APA no período 2012-2018 ............................. 90

Figura 19 - Mapa do projeto do Hidroanel do canal navegável do rio Tietê (folha 1) ............... 94

Figura 20 - Mapa do projeto do Hidroanel do canal navegável do rio Tietê (folha 2)................. 95

Figura 21 - Mapa do projeto do Hidroanel do canal navegável do rio Tietê (folha 3)................. 96

Figura 22 - Propostas para o transporte sobre trilhos no PITU 2020 …...................................... 98

Figura 23 - Trajeto do Ferroanel e área de impacto direto e indireto......................................... 101

Figura 24 - Mapa síntese das sobreposições planos e projetos na APAVRT no trecho Oeste.. 105 Figura 25 - Mapa síntese das sobreposições planos e projetos na APAVRT no trecho Leste (folha 1) 106

Figura 26 - Mapa síntese das sobreposições planos e projetos na APAVRT no trecho Leste

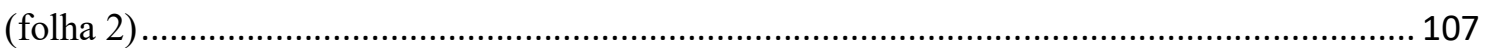

Figura 27 - Mapa do uso do solo das áreas a serem alagadas na APA (folha 1)....................... 109

Figura 28 - Mapa do uso do solo das áreas a serem alagadas na APA (folha 2)....................... 110

Figura 29 - Mapa de grau de perturbação morfológica das áreas a serem alagadas.................... 113

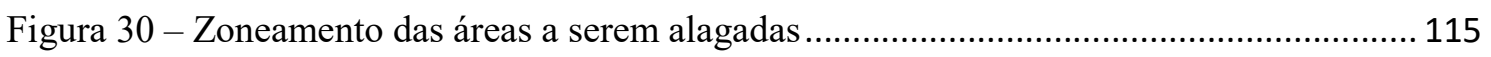

Figura 31 - Estrutura da governança do PVT ................................................................... 120 


\section{Lista de Quadros}

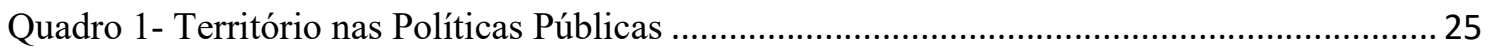

Quadro 2 - Principais propostas e etapas da retificação do rio Tietê ............................................. 35

Quadro 3 - Quadro com os planos e projetos e suas escalas ......................................................65

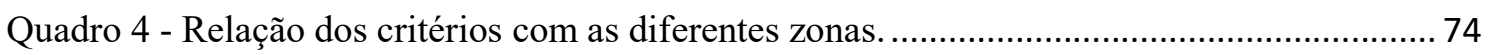

Quadro 5 - Adulterações na minuta do decreto identificadas pelo Ministério Público ................. 80

Quadro 6 - Novas quantidades previstas no Contrato de Empréstimo ........................................ 86

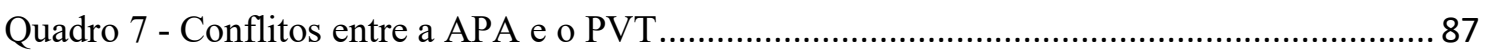

Quadro 8 - Modelo aplicado para o território da APA da Várzea do Rio Tietê........................... 103

Quadro 9 - Síntese dos planos, programas e projetos e a participação social ............................. 127

\section{Lista de Tabelas}

Tabela 1- Evolução dos pontos críticos de inundações no município de São Paulo..................... 38

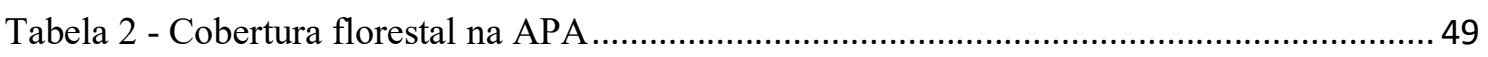

Tabela 3 - Área de intervenção e área alagada proposta - série 100 e série 200........................ 93

Tabela 4 - Cálculo do Uso do Solo das Áreas a serem alagadas............................................. 111

Tabela 5 - Cálculo do Uso do Solo das Áreas de margem ........................................................ 112

Tabela 6 - Representantes da sociedade civil por município e biênio....................................... 119

Tabela 7 - Distribuição dos representantes por setor. .............................................................. 122

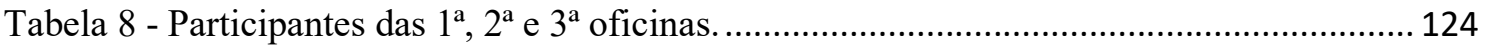

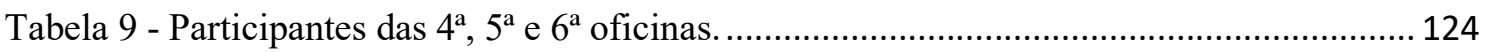




\section{Lista de Siglas}

APA - Área de Proteção Ambiental

APAVRT - Área de Proteção Ambiental da Várzea do Rio Tietê

APQC - Associação dos Pesquisadores Científicos do Estado de São Paulo

BID - Banco Interamericano de Desenvolvimento

CIESP - Centro das Indústrias do Estado de São Paulo

CONSEMA - Conselho Estadual de Meio Ambiente

CPLA - Coordenadoria de Planejamento Ambiental

CPTM - Companhia Paulista de Trens Metropolitanos

DAEE - Departamento de Águas e Energia Elétrica

DERSA - Desenvolvimento Rodoviário S.A.

DH - Departamento Hidroviário

EACH - Escola de Artes, Ciências e Humanidades

EMPLASA - Empresa Paulista de Planejamento Metropolitana S/A

EPL - Empresa de Planejamento e Logística S.A.

FFLCH - Faculdade de Filosofia, Letras e Ciências Humanas

FIESP - Federação das Indústrias do Estado de São Paulo

FF - Fundação para a Conservação e a Produção Florestal do Estado de São Paulo

MPSP - Ministério Público do Estado de São Paulo

PBHAT - Plano de Bacia Hidrográfica do Alto Tietê

PDUI - Plano de Desenvolvimento Urbano Integrado

PVT - Programa Várzeas do Tietê

RIMA - Relatório de Impacto Ambiental

RMSP - Região Metropolitana de São Paulo

SABESP - Companhia de Saneamento Básico do Estado de São Paulo

SELT - Secretaria Estadual de Logística e Transporte

SISNAMA - Sistema Nacional de Meio Ambiente

SMA - Secretaria de Meio Ambiente

SNUC - Sistema Nacional de Unidades de Conservação

SVMA - Secretaria do Verde e do Meio Ambiente

TAV - Trem de Alta Velocidade

ZEE - Zoneamento Ecológico-Econômico 


\section{Sumário}

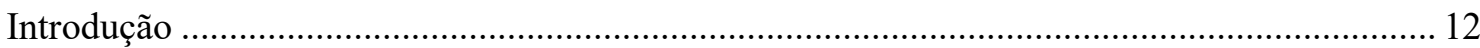

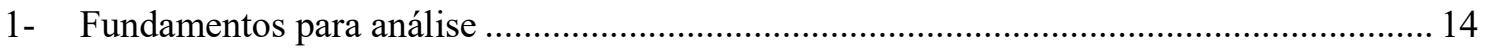

1.1 - Geografia Política: temas e conceitos ........................................................................ 15

1.2 - Fundamentos de políticas públicas e principais categorias geográficas: um caminho metodológico à compreensão do processo territorial na APAVRT ......................................... 16

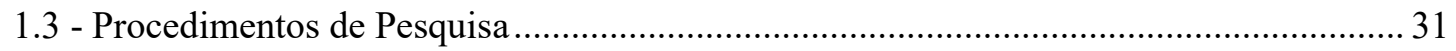

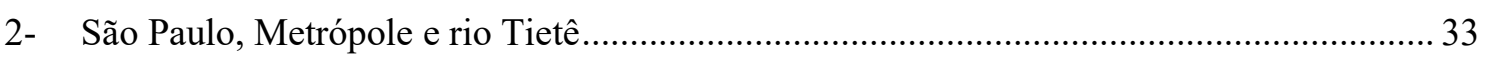

2.1 - APA da Várzea do Rio Tietê: contexto histórico, processos políticos e território........... 41

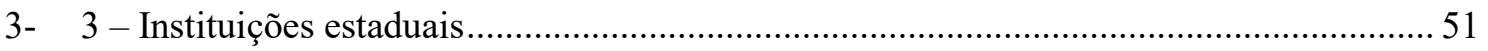

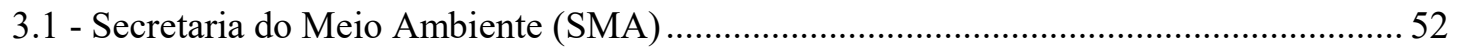

3.2 - Conselho Estadual de Meio Ambiente (CONSEMA).................................................... 54

3.3 - Fundação para Conservação e a Produção Florestal do Estado de São Paulo (FF) ......... 55

3.4 - Departamento de Águas e Energia Elétrica (DAEE) ......................................................... 56

3.5 - Comitê de Bacia Hidrográfica do Alto Tietê (CBHAT) ………....................................... 56

3.6 - Empresa Metropolitana de Planejamento da Grande São Paulo S/A (EMPLASA) ....... 57

3.7 - Desenvolvimento Rodoviário S/A (DERSA) ………………………………............... 58

3.8 - Companhia Paulista de Trens Metropolitanos (CPTM) ................................................... 58

3.9 - Companhia de Saneamento Básico do Estado de São Paulo (SABESP) ........................... 59

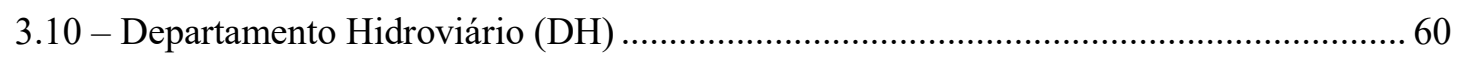

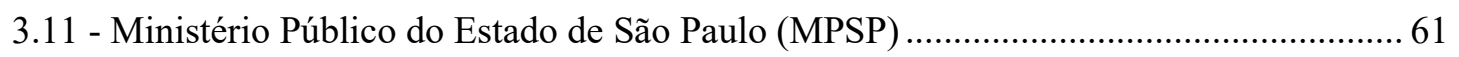

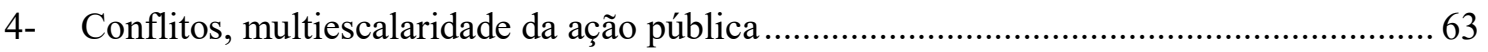

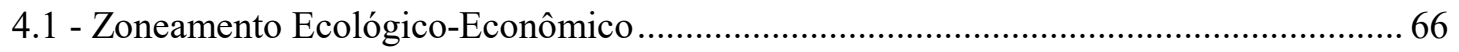

4.2 - Plano de Desenvolvimento Urbano Integrado (PDUI) ………………………............... 67

4.3 - Plano de Bacia Hidrográfica do Alto Tietê (PBHAT) ...................................................... 70

4.4 - Programa de Despoluição do Rio Tietê ........................................................................... 71

4.5 - Plano de Manejo da APA da Várzea do Rio Tietê.............................................................. 73

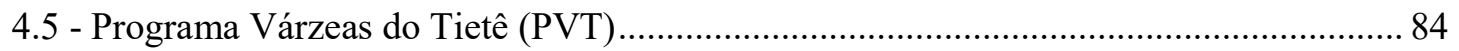

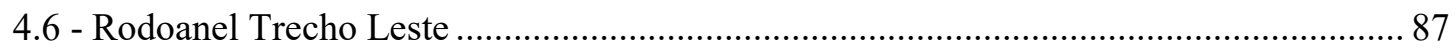

4.7 - Hidroanel Metropolitano de São Paulo .............................................................................. 91

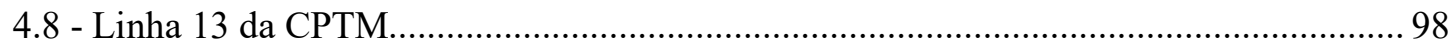

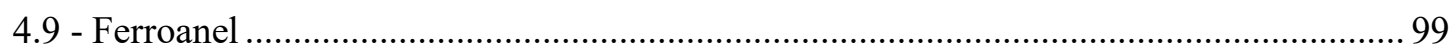

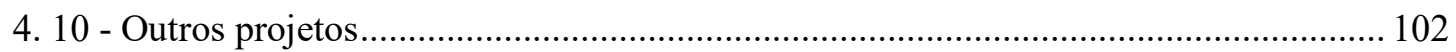

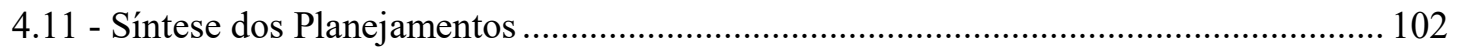

5- 5 - Governança, Articulação Institucional e Participação Social ........................................ 117

5.1 - APA VRT: Conselho Gestor e CONSEMA …………………................................... 117 
5.2 - Articulação institucional do PVT

5.3 - Plano de Desenvolvimento Urbano Integrado (PDUI) ................................................. 121

5.4 - Oficinas participativas do Plano de Bacia Hidrográfico do Alto Tietê........................... 123

5.5 - Audiências Públicas Projeto Tietê IV ......................................................................... 125

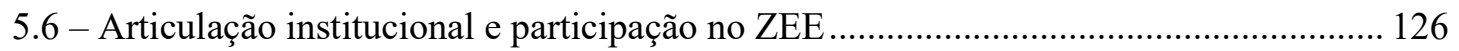

5.7 - Síntetizando os Espaços de Participação ……………………………………................... 126

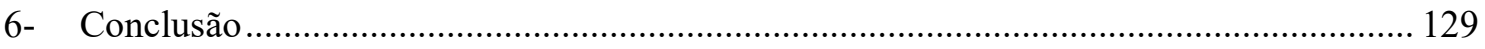

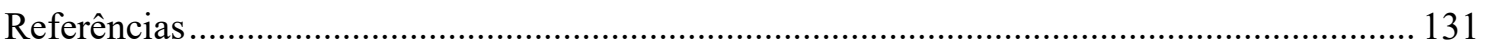




\section{Introdução}

O interesse por trabalhar com o tema desta dissertação veio depois de ter trabalhado na elaboração do Plano de Manejo da Área de Proteção Ambiental da Várzea do Rio Tietê (APAVRT), estudado na USP Leste (localizada dentro na APA) e ter feito o Projeto Formatura sobre a relação da APAVRT com os planos diretores municipais, vendo o processo demorado e conflituoso de aprovação do Plano. A pergunta inicial da pesquisa surgiu a partir dessas sobreposições e da inquietação com a demora do processo da aprovação do Plano em detrimento de outras políticas, que eram muito impactantes e se desenvolviam com maior celeridade. Durante o desenvolver da pesquisa ainda seria surpreendido com a adulteração do plano, sua consequente suspensão e, no fim, com a triste notícia de que todo o processo e o plano haviam sidos anulados.

Tratar desse tema é de grande relevância, considerando que a APA é um tipo de Unidade de Conservação (UC) que permite atividades humanas e se almeja a sustentabilidade do território, mas que possui diversas dificuldades de gestão e sofre muitas pressões. Também é preponderante que a área de estudo se insere no bioma da Mata Atlântica, com remanescentes vegetais de florestas ombrófila densa, de várzea e paludosas, e espécies ameaçadas como o Bicudinho do Brejo (Formicivora aff. Acutirostris) (FF, 2013). Destaca-se também que essa área está situada na maior metrópole da América Latina e sujeita às diversas pressões urbanas, como obras de infraestrutura e de expansão urbana.

A presente pesquisa teve como objetivo analisar os diferentes planejamentos existentes para a APA da Várzea do Rio Tietê e os conflitos decorrentes, com foco nos órgãos estaduais Fundação Florestal, Departamento de Águas e Energia (DAEE), comitê da bacia Alto Tietê, Secretaria de Logística e Transportes, Companhia Paulista de Trens Metropolitanos (CPTM), bem como as lógicas de desenvolvimento e de governança associadas.

O primeiro capítulo contextualiza a pesquisa partir do referencial teórico da geografia política aliado com os estudos de políticas públicas que fundamentam a pesquisa. São abordados os conceitos e os instrumentos analíticos utilizados pela pesquisa e sua evolução histórica.

O segundo capítulo se refere ao território da APA da Várzea do Rio Tietê e como se insere na metrópole historicamente e espacialmente. É abordada a história do rio Tietê 
a partir das diferentes apropriações e projetos pensados para solucionar o rio, até a criação da APA e suas características principais.

No terceiro capítulo são listadas e descritas as principais instituições estaduais que atuam no território da APA. As instituições são descritas a partir de sua criação, seu escopo e como se alteraram ao longo do tempo.

No quarto capítulo são listados e descritos os planos, programas e projetos realizados por cada uma das instituições listadas no terceiro capítulo e que incidem no território da APA. A partir da sobreposição desses planos, programas e projetos é feita uma síntese cartográfica analisando os conflitos.

No quinto capítulo é analisada a articulação desses planos, programas e projetos a partir da governança. Nesse âmbito é analisada a articulação entre cada uma das instituições, assim como as esferas de participação social de cada uma. 


\section{1- Fundamentos para análise}

O Rio Tietê nasce em Salesópolis e atravessa o estado de São Paulo, até desaguar no rio Paraná. Outrora foi um rio importante em razão do seu percurso, que permitiu as Bandeiras e as Monções, segundo a narrativa da historiografia paulista, elementos cruciais para a expansão territorial brasileira no período colonial e onde se estabeleceram importantes núcleos de ocupação. Atualmente é explorado para a navegação (Hidrovia Tietê-Paraná), uso energético, abastecimento público, além de abrigar em suas margens a maior metrópole da América do Sul. Também se destaca, no aspecto ambiental, pelo impacto da metrópole nos 137 km de poluição no rio (PAGANINI, 2008; SOSMA, 2017).

$\mathrm{O}$ enfoque desta pesquisa é no trecho do rio Tietê na Região Metropolitana de São Paulo (RMSP) e, mais precisamente, na Área de Proteção Ambiental da Várzea do Rio Tietê (APA VRT). O entorno do rio Tietê na RMSP tem uma grande importância e passou por diversos usos, apropriações e impactos, para os quais se tem proposto diversas soluções e projetos de recuperação, otimização ou mesmo de regeneração. É um território disputado por diversos grupos da sociedade civil (movimentos sociais, agentes econômicos, etc.), instituições governamentais e é objeto de múltiplos planos, que se definem ao longo do rio Tietê na RMSP, implicando em uma crescente complexidade jurídica e de governança. Neste contexto foi selecionada, como objeto de análise, a APAVRT, que se destaca nas tentativas de promover a gestão/governança de um território complexo, tendo como pressuposto critérios ambientais, de sustentabilidade e participação social. Entretanto, a APAVRT, assim como outras APAs, apresenta grande dificuldade na sua gestão e na definição dos usos permitidos, com a morosidade e os conflitos sobre os tipos de atividades e desenvolvimento (CÔRTE, 1997; SILVA 2006). Para uma investigação do efeito e das condições políticas em que se insere a APA, será feita uma abordagem a partir da contribuição da geografia política com um enfoque territorial para os processos políticos e conflitos decorrentes.

A Geografia Política é fundamental como base para as reflexões da presente pesquisa, por tratar da relação entre território e política. Sendo assim, esta será brevemente explorada a seguir, tendo como base o trabalho de diversos autores, como André-Louis Sanguin, Wanderley Messias da Costa, Iná Elias de Castro e Claude Raffestin. 


\section{1 - Geografia Política: temas e conceitos}

A Geografia Política tem sua origem com os trabalhos de Friedrich Ratzel, que procurou estabelecer a relação do Estado com o solo/território (RAFFESTIN, 1993; COSTA, 2016). A relação, definida por Ratzel, tinha forte componente ecológico, pois ele havia sido estudante de Haeckel, que cunhou o termo "ecologia" e tentava estabelecer a relação dos fatores de influência ambientais na humanidade, sendo denominado posteriormente como a escola "Determinista" ou "Ambiental" (MORAES, 1990; COSTA, 2016).

Haveriam outros autores importantes, como Vidal de La Blache e Camille Vallaux, que se opuseram as propostas de Ratzel com a escola "Possibilista", dando destaque para os aspectos sociais e adaptação ao meio (RAFFESTIN, 1993; COSTA, 2016). Entretanto, é a partir dos trabalhos de Ratzel se desenvolveria a "Geopolítica", termo criado por Kjellen (RAFFESTIN, 1993, COSTA, 2016).

Segundo Costa (2016) a geopolítica tem um caráter mais aplicado e voltado para questões de defesa e estratégia, diferentemente da geografia política, que estaria focada nas discussões teóricas sobre a relação do Estado com território. O uso da geopolítica por Hausofer e outros geógrafos durante o nazismo implicou em uma forte rejeição da geografia por diversos acadêmicos de outros campos (SOJA, 1993).

Posteriormente, a geografia política foi retomada, mas com mudanças importantes em suas definições. A dita clássica seria definida por Raffestin (1993) como uma geografia do Estado. Autores como Raffestin (1993) e Sanguin (1977) apontaram as mudanças no Estado e na sociedade, redistribuindo-se o poder entre os diversos atores. A geografia política, segundo Sanguin (1977) e Castro (2005), é um campo de estudo da relação entre política e território, pois a partir das relações sociais inseridas no espaço, os conflitos decorrentes e ações se territorializam, no esforço de organizar o território.

Para Raffestin (1993), a Geografia Política se define por uma geografia do poder ou dos poderes, analisando o poder a partir das relações e não mais centrada na figura do Estado como elemento único. Raffestin (1993) incluiu na análise atores provenientes da sociedade e da esfera econômica, além dos atores estatais em seu sistema territorial.

Costa (2016), ao analisar a evolução da Geografia Política, também verificou uma importante preponderância de Estado, nação, território e fronteiras até o período da década de 1950. O autor também descreve o surgimento e a subsequente rejeição da Geopolítica como uma pseudociência, além da produção marcada pelos conflitos internacionais das guerras. Posteriormente, o debate será centrado no poder, com a 
ampliação da sociedade nos processos decisórios e na gestão, incorporando e mudando o enfoque do poder, a organização e gestão dos espaços nacionais e a autonomia regional e local (COSTA, 2016). O autor, por outro lado, destaca que, apesar de ser proposta uma “desestatização" da Geografia Política, o Estado Moderno exige uma reflexão sobre seu caráter para que seja considerada uma ciência social e possa se relacionar com a ciência política.

Os anos 1990 até 2015 foram marcados pela alteração da reestruturação das relações de poder entre os países; a tecnologia e a difusão das comunicações ganharam contornos muito importantes para os debates da Geografia Política (SANGUIN, 2016). Segundo Sanguin (2016), a produção acadêmica vai tratar, além dos conceitos básicos da disciplina, de temas que ganharam espaço na agenda da sociedade, como o feminismo, o glocal, o terrorismo, as fronteiras marítimas dentre outros.

Para os geógrafos supracitados, a configuração do Estado, a política e a relação com os múltiplos atores da sociedade são imprescindíveis para as análises da geografia política. Consequentemente, para analisar esses aspectos, recorreu-se à literatura de Políticas Públicas, que trata da influência da configuração do Estado atual no processo político e a participação da sociedade em seus processos.

Para tal reflexão, será explorado o conceito de "políticas públicas" e sua associação com território, além das definições de "território", e por fim, a categoria das "políticas territoriais" como um grupo distinto.

\section{2 - Fundamentos de políticas públicas e principais categorias geográficas: um caminho metodológico à compreensão do processo territorial na APAVRT}

Políticas públicas possuem diversas interpretações, por ser um campo em formação. Para Thomas Dye (2008), a política pública é o que o Estado decide fazer ou não, definição associada ao início deste campo, quando as análises eram centradas na ação do estado, de caráter top-down (MASSARDIER, 2003). Gilles Massardier (2008) define o termo como uma decisão pública voltada a um objetivo definido e num dado processo para atingi-lo, o que já compreende a participação e articulação com atores não estatais. Atualmente, o Estado ainda possui um papel importante, pois pode impor a política pública (DYE, 2008). Porém, o processo de sua elaboração tem-se complexificado e exigido a participação de diversos atores sociais (MASSARDIER, 2003). As políticas públicas são direcionadas para setores da sociedade ou territórios (MASSARDIER, 2003). 
Massardier (2003) e Souza (2006) apresentam uma síntese com base nas diversas correntes e modelos que se desenvolveram nos estudos de políticas públicas, como: as políticas em quatro formatos (distributivas, regulatórias, redistributivas e constitutivas), o incrementalismo, o ciclo de políticas públicas, o garbage can, a coalizão de defesa, arenas sociais, de equilíbrio interrompido e modelos influenciados pelo novo "gerencialismo público". A autora apresenta a seguinte compreensão de políticas públicas:

\footnotetext{
No entanto definições de políticas públicas, mesmo as minimalistas, guiam o nosso olhar para o locus onde os embates em torno de interesses, preferências e idéias se desenvolvem, isto é, os governos. Apesar de optar por abordagens diferentes, as definições de políticas públicas assumem, em geral, uma visão holística do tema, uma perspectiva de que o todo é mais importante do que a soma das partes e que indivíduos, instituições, interações, ideologia e interesses contam, mesmo que existam diferenças sobre a importância relativa destes fatores. (SOUZA, 2006, p.25)
}

A partir das políticas públicas se deriva "planos, programas, projetos, base de dados ou sistemas de informações e pesquisas" (SOUZA, 2006, p.26). Para esta pesquisa serão analisadas políticas públicas em diferentes níveis, compreendendo desde planos a projetos, discutidos no capítulo 3.

Para os geógrafos, segundo Rodrigues (2014), políticas públicas são um tema recente de modo geral e ainda pouco explorado. Outra definição a ser destacada é a definida pela autora, que procura pontuar a importância das políticas públicas para a geografia humana:

\footnotetext{
Para uma definição mínima, por políticas públicas entendemos intervenções de autoridades investidas de poder público e de legitimidade para afetar comportamentos e práticas em limites territoriais precisos; ou simplesmente, 'tudo o que os atores governamentais decidem fazer ou não fazer' (Thoenig, 1985), ordenando as práticas sociais em limites territoriais identificáveis e mensuráveis. (RODRIGUES, 2014, p.155, grifo nosso)
}

O entendimento de que as políticas têm uma dimensão territorial é evidente pela definição grifada na citação acima. No entanto, o seu estudo em conjunto com as políticas públicas é um tema recente.

Mello-Théry (2011a) também observa uma retomada das políticas públicas pelos geógrafos após uma decadência desse tema em razão dos modelos de Estado Mínimo. Segundo a autora, já existia a aproximação dos geógrafos com as políticas públicas, principalmente àquelas relacionadas ao território e ao espaço no âmbito do planejamento 
governamental na década de 1940. Contudo, houve um afastamento desses estudos, principalmente após o fim da ditadura militar. Esta retomada dos estudos das políticas públicas se concentra na "grande linha teórica, crítica, de base marxista e/ou estruturalista" (MELLO-THÉRY, 2011a, p. 14).

$\mathrm{Na}$ literatura sobre planejamento e políticas públicas, defrontamo-nos com diversos conceitos da geografia, como "região", "espaço" e "território". Entre estes conceitos, o de "região" inseriu-se na agenda do planejamento no Brasil no fim da década de 1950 (SILVA, 2017). Segundo Marília Steinberger (2006), a partir da década de 1980 o espaço passou a ser incorporado nos estudos de políticas, no qual se observava a distribuição desigual das políticas públicas pelo espaço. No entanto, também havia estudos que restringiam o espaço como o endereço de uma política pública. Para Silva (2017), o marco desta mudança é a Constituição Federal de 1988, na qual há a descentralização do poder (com destaque para os municípios); a lógica de desenvolvimento a nível local; consórcios, regiões metropolitanas e RIDEs ${ }^{1}$ como instrumentos de planejamento; a administração gerencial; a ênfase na integração econômica das regiões e o planejamento participativo. Estes elementos, destacados pela autora, são importantes porque colocam a política pública atrelada à escala e ao território.

"Território" é um conceito que se tem popularizado nas análises geográficas (FERNANDES, 2015; SAQUET, 2007) no campo das políticas públicas da década de 1990 (SILVA, 2012, 2013; RODRIGUES, 2014; FERNANDES, 2015), ainda que não seja somente um conceito geográfico. Ele tem sua origem na etologia e seu uso irá surgir dos estudos de ornitologia de Howard na década de 1920 (BONNEMAISON, 1981).

Para desenvolver analiticamente a problemática desta pesquisa, deve-se primeiramente explorar a diferença dos conceitos geográficos de "região", "espaço" e "território"; assim como também a definição de "políticas públicas" e, por fim, como estes conceitos são relacionados.

O conceito de "Região"2 parte de critérios marcados pelas condições naturais e pelos processos produtivos: a primeira a partir da noção da diferenciação das áreas,

\footnotetext{
${ }^{1}$ Regiões Integradas de Desenvolvimento.

${ }^{2}$ A presente discussão sobre Região é decorrente das atividades, promovidas ao longo do ano de 2016 pelo Grupo de Estudos de Epistemologia da Geografia, vinculado ao Laboratório de Estudos Regionais em Geografia (LERGEO) do Departamento de Geografia da USP. O Grupo é composto por Simone Affonso
} 
definidas pela geografia tradicional, pautadas nas áreas homogêneas e naturais (VIDAL DE LA BLACHE, 1954; HARTSHORNE, 1978). Sucede-se a abordagem, contrapondo uniformidade e unidade das áreas a partir do meio natural e das cidades, esboçando um olhar a partir das atividades econômicas (GUIMARÃES, 1942, 1963; JULLIARD, 1982), com maior enfoque no aspecto industrial e produtivo (CHORLEY, HAGGET, 1974; GEORGE, 1966; CERON, 1977; FAISSOL, 1972, 1975, 1978); por último, a visão da geografia crítica, que incorpora o materialismo dialético, e a região passa a ser definida pela concentração do capital, a luta de classes, a divisão territorial do trabalho, a dimensão política e a relação do Estado com a sociedade local (CORRÊA, 2000).

O conceito de "espaço" foi explorado por diversos autores nas ciências sociais, na economia, arquitetura e na geografia. Nestas diversas áreas, "espaço" ganhou diferentes conotações e foi marcado por processos históricos e políticos. Soja (1993) resgata o processo de abandono do "espaço" em razão do uso das teses ratzelianas pelo nazismo alemão e defende que seria uma categoria marginal, até ser recolocada no debate das ciências sociais a partir de Foucault. Para Milton Santos (2008), "espaço" se caracteriza a partir de elementos básicos, que seriam "os homens, as firmas, as instituições, o chamado meio ecológico e as infraestruturas" e estes se estruturam em um sistema na qual a totalidade se define a partir das interações (SANTOS, 2014, p.16).

O conceito de espaço também já foi tema de diversos pesquisadores das ciências sociais e, mesmo havendo produções desde o começo do século XX, esse conceito só se tornou um tema explícito de pesquisa nas duas últimas décadas do século com nomes como Foucault (2013), Lefebvre (2013) e Bourdieu (2013), que o trataram a partir das relações sociais (FREHSE, 2013).

Foucault (2013) trata o espaço como um conjunto de relações que define os lugares e sua relação com a sociedade, variando com o momento histórico, com funções específicas, com funcionamentos e fluxos específicos. O autor ainda classifica em dois grandes grupos das utopias (espaços ideais que influenciam os demais) e heteropias (espaços existentes com funções, relações etc.) (FOUCAULT, 2013). Lefbvre (2013) é outro importante autor que irá refletir sobre o espaço a partir da produção. Nesse âmbito 
o espaço é resultado da produção da sociedade e dos seus meios de produção e, por outro lado, também é suporte dessas relações e produção e, dessa maneira, se dialetiza como produto-produtor. Bourdieu (2013) argumenta que o espaço social se retraduz no espaço físico, e define os conceitos de habitat e habitus.

"Território" tem uma série de interpretações distintas e sua origem etimológica é discutida pelos sentidos de terra ou de terror (direito sobre a terra) (HAESBAERT, 2004). A origem do termo está associada com os estudos de naturalistas e ganha projeção na geografia a partir dos trabalhos de Ratzel, que inicialmente teve sua formação na área de zoologia com Haeckel (COSTA, 2016). Ratzel (2011) entendia o Estado como um organismo que era inconcebível sem o território/solo ${ }^{3}$ e que, portanto, deveria assegurar o seu território. Raffestin (1993) critica esta leitura que é centrada em um Estado central e não considera as diversas escalas de organização e formações territoriais por outros grupos.

Rogério Haesbaert (2004) em "O Mito da Desterritorialização" observa que "território" possui diversas interpretações, variando de acordo com as áreas de conhecimento e mesmo entre geógrafos. $\mathrm{O}$ autor divide as interpretações em três vertentes básicas (Política, Cultural e Econômica) e explora em seguida a partir das perspectivas mais materialistas (naturalista, como base econômica, jurídica-política) e idealista.

Desde a sua origem na geografia, o território está relacionado com a compreensão de poder, haja vista autores clássicos como Friedrich Ratzel e, mais recentes, como Claude Raffestin, Marcos Aurélio Saquet, Marcelo Lopes de Souza, Bernardo Mançano Fernandes e Rogério Haesbaert. Segundo Saquet (2007) a compreensão de território se alterou ao longo do tempo em conjunto com o entendimento de poder.

Souza (2015) tem como crítica a "coisificação" do território, o que o autor define como apreender exclusivamente o território como a materialidade. Para o autor, o território está definido pelo poder. Souza (2015) define poder como a capacidade de impor normas e regras, associado usualmente ao Estado, ou de autonomia, relacionado à

\footnotetext{
3 Na reedição e tradução do "O solo, a sociedade e o Estado" Ratzel utiliza o termo solo como território para defender sua tese do caráter basal e de sustento que o solo/território possuía para o Estado (RATZEL, 2011).
} 
comunidade e grupos locais com capacidade de se autogerir, em relação a uma materialidade.

Raffestin (1993, 2012) define "poder" a partir de sua interpretação de Foucault, a qual é baseada no trabalho e também defende que o poder vem de baixo. "Território", segundo Raffestin $(1993,2015)$, surge a partir da apropriação do espaço por algum ator:

O território se forma a partir do espaço, é o resultado de uma ação conduzida por um ator sintagmático (ator que realiza um programa) em qualquer nível. Ao se apropriar de um espaço concreto ou abstratamente (por exemplo pela representação), o ator 'territorializa' o espaço. (RAFFESTIN, 1993, p.143, grifo nosso)

Esta leitura compreende os atores do Estado, como econômicos e sociais. É uma definição com um forte referencial na semiótica como meio de apropriação e em que, inclusive, a representação cartográfica figura como uma apropriação do espaço (RAFFESTIN, 1993, 2012; KLAUSER, 2012). O autor destaca também que território está associado às noções de limite e transgressão (RAFFESTIN, 2012). Os limites podem ser mais ou menos estáveis, considerando o tipo de ator. Em vista disso, o território dos atores políticos tende a ser mais perene em comparação aos atores econômicos (RAFFESTIN, 1993).

O território se forma a partir da apropriação do espaço, segundo Raffestin (1993, 2012, 2015), a partir do trabalho. O autor define este processo como:

O território é um estado de natureza no sentido em que Moscovici define a noção: este (território) se refere ao trabalho humano aplicado sobre um complexo de forças e ações mecânicas, físicas, químicas, orgânicas e outras (RAFFESTIN, 2012, p.129, tradução nossa ${ }^{4}$ ).

Para o autor, o trabalho é composto por energia e informação e tem um caráter importante para a transformação territorial (RAFFESTIN, 1993; 2015). No entanto, ele também observa que há uma separação entre "trabalho material" e "trabalho intelectual"; em outras palavras, entre trabalho de transformação da materialidade e da representação desta (RAFFESTIN, 2012).

\footnotetext{
4" A territory is a state of nature in the sense in which Moscovici defines the notion: it refers to human labor exercised on a complex combination of mechanical, physical, chemical, organic, and other forces and actions."
} 
Em trabalhos posteriores, Raffestin $(2012$, 2015) sintetiza a relação dos atores com o território a partir de um modelo (figura 1). Modelos vão ter destaque na geografia a partir da Geografia Nova ou Quantitativa, com a inserção dos modelos como ferramentas de análise (CHRITOFOLETTI, 1982). Diferente dos modelos associados à geografia física, o modelo proposto por Raffestin propõe as variáveis a serem consideradas para a análise do território sem recorrer aos métodos quantitativos e estatísticos. Deve-se destacar que, entre as variáveis destacas, considera-se o ambiente construído/social e o meio biótico e abiótico. Marchand (2002) também propôs um modelo para análise da realidade a partir do território. O modelo de Marchand (2002) tem como base sistemas da análise espacial para trabalhar com desastres e riscos associados a mudanças climáticas. Raffestin $(2012,2015)$ considera a interação de múltiplos fatores em seu modelo ${ }^{5}$ representada na seguinte figura:

Figura 1 - Modelo conceitual do processo territorial.

$$
\begin{aligned}
& \text { A(L-M-P-R-S }(\mathrm{Sn} / \mathrm{So})=\mathrm{T} / \mathrm{Ta} \\
& \mathrm{A}^{\prime}(\mathrm{L}-\mathrm{M}-\mathrm{P})-\mathrm{R}-[\mathrm{A}(\mathrm{L}-\mathrm{M}-\mathrm{P})-\mathrm{R}-\mathrm{S}(\mathrm{Sn} / \mathrm{So})=\mathrm{T} / \mathrm{Ta}]=\mathrm{T}^{\prime} / \mathrm{Ta}{ }^{\prime} \\
& \text { A"(L-M-P)"-R" = [A'(L-M-P)-R-(A(L-M-P)-R-S(Sn/So ) = T/Ta) = T'/Ta'] = T"/Ta" } \\
& \mathrm{SgG}(\mathrm{T} / \mathrm{Ta})
\end{aligned}
$$

Neste modelo, os elementos básicos para intervir no ambiente são o trabalho (L), os mediadores $(\mathrm{M})$ e o programa $(\mathrm{P})$ projetados no ambiente $(\mathrm{S})$ por uma relação $(\mathrm{R})$ do ator (A) produzindo um território (T) (RAFFESTIN, 2015). O território (T) é a parte

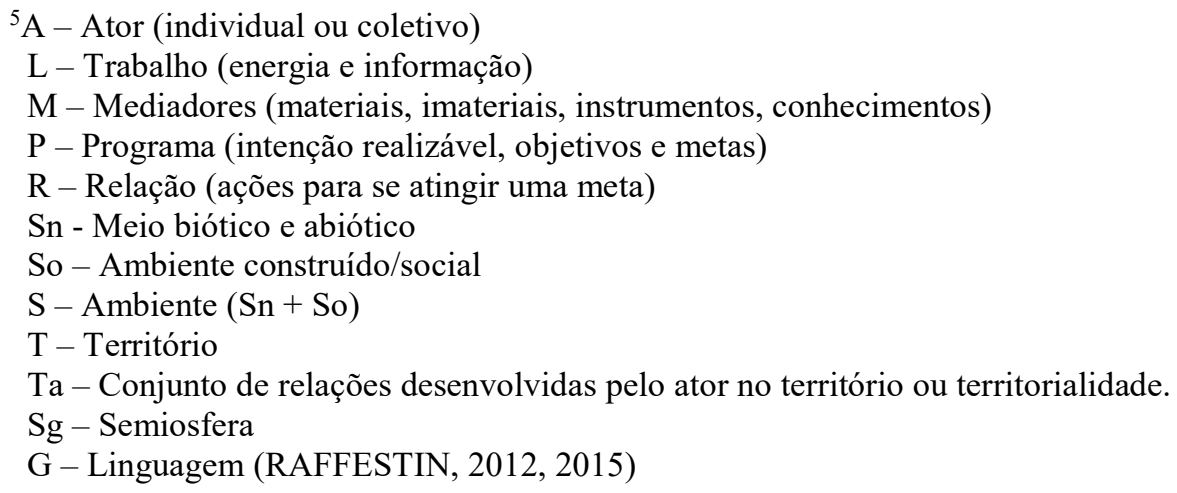


material e implica em uma territitorialidade (Ta), que é a parte imaterial (RAFFESTIN, 2015).

Para Raffestin (2015) existe uma sobreposição de territórios e territorialidades (T/Ta) em que cada T/Ta são criados sobre outros territórios pré-existentes. Neste processo $\mathrm{S}(\mathrm{Sn} / \mathrm{So})$ equivale a "A(L-M-P-R-S(Sn/So)=T/Ta" preexistentes, o que resulta na equação da segunda e terceira linha. Por fim, na última linha, o autor coloca a relação da semiosfera $(\mathrm{Sg})$ com a linguagem $(\mathrm{G})$ sobre um dado território e territorialidade $(\mathrm{T} / \mathrm{Ta})$ implica em uma paisagem, elemento que é destacado como recurso para se investigar a territorialidade.

Raffestin (1993) destaca que o território existente é resultado da sobreposição e interação das múltiplas apropriações simbólicas do território pelos diferentes atores sintagmáticos. Mello-Théry (2011a) tem uma análise próxima sobre o Estado com o território:

\footnotetext{
O que ocorre em um território não é exclusivamente resultado das decisões, atuações e processos que ocorrem em seu interior (intrapoder), mas estas são afetadas, em maior ou menor grau, por decisões e atuações exteriores (interpoder) ao território considerado. (MELLO-THÉRY, 2011a, p. 13)
}

Para Fernandes (2015), o território pode ter duas leituras: uma como espaço de governança e outra a partir das relações sociais e das classes sociais em conflito pelo modo de desenvolvimento e de sociedade. Destaca-se também que os territórios, produzidos pelas relações e classes socais, produzem estas mesmas relações e classes (FERNANDES, 2015). O autor tem como referencial os territórios rurais na elaboração de sua proposição. Fernandes (2015) classifica, a partir destas leituras, o território em 3 níveis: o primeiro de governança (compreende o território do Estado e em seus múltiplos níveis da nação a municipalidade), o segundo com relação a propriedade definida como espaço da vida (particular ou comunitária) e o terceiro pelo uso do território (territorialidades), consequência dos conflitos de classes, grupos sociais, sociedade e Estado.

Raffestin (1993), Fernandes (2015) e Souza (2015) colocam em destaque o território imaterial como elemento de transformação. Este território imaterial tem o sentido de orientar a apropriação e o uso a ser dado para o espaço interferindo pela apropriação na esfera do planejamento, no exercício de poder e no conflito de projetos para o uso do território. 
Haesbaert (2004) observa que os processos naturais também interferem na construção dos territórios. Para tanto, considera-se os aspectos sociais e tecnológicos.

Para esta pesquisa a analise, a partir de conflitos e da relação de poder, o conceito de território apresenta-se como elemento chave de análise para a APAVRT. Com base nesta literatura sobre território, será discutido o território da APAVRT (subtópico 2.1), considerando os processos políticos, geográficos e históricos. Entretanto, analisando os processos de transformação territorial, ressalta-se que existem outros territórios de ordem simbólica tensionados com a APA e que geram um processo conflituoso e contraditório. Neste processo de transformação, destaca-se a ação e contradição do Estado. Para este propósito, será explorada a compreensão das políticas territoriais (ou políticas públicas em relação com território) que interferem neste processo, as políticas públicas/territoriais a partir da policy analysis e a análise do Estado a partir de suas instituições públicas, como um conjunto de atores com intencionalidades e territórios distintos que se sobrepõem à APA.

A abordagem territorial para o estudo das políticas públicas tem um caráter importante, pois:

Assim, a abordagem territorial para o planejamento de políticas públicas auxilia no entendimento dos fenômenos sociais, contextos institucionais e cenários ambientais sob os quais ocorrerá a intervenção desejada, de maneira a propiciar meios mais acurados para a definição e alcance de metas, parcerias necessárias e instrumentos de implementação. (SILVA, 2012, p.153)

Revisando a literatura, com relação à abordagem territorial e as políticas públicas, foram encontrados diversos autores. No entanto, destacam-se algumas distinções conceituais nesses estudos, como Massardier (2003) e Silva (2013), que tratam da relação entre o território e as políticas públicas, enquanto outros, como Ruckert (2004), Sellers (2010), Mello-Théry (2011b), Borges (2012), Silva Jr. (2016) trabalham com a categoria de políticas territoriais, além de Steinberger (2006), que defende a noção de políticas espaciais.

Steinberger (2006) defende uma classe maior de políticas espaciais, que compreenderiam as demais políticas: territorial, ambiental, regional, urbana e rural, com base na compreensão de espaço geográfico de Milton Santos. A autora investiga o porquê destas categorias se enquadrarem nesse grupo maior a partir da conceituação do espaço e da compreensão de um caráter inerentemente espacial nestas políticas, a partir da 
compreensão de que as categorias que se enquadram nas políticas espaciais como frações do espaço ou do território.

Segundo Mello-Théry (2011a, 2011b), por outro lado, as políticas territoriais são a categoria maior. Segundo a autora, são aquelas que têm como fundamento a transformação do espaço para outras espacializações como a urbana, regional, de transportes etc. e atender aos interesses que controlam o processo político.

Silva (2017) verificou, no entanto, que há uma tendência na administração pública de compreender a dimensão territorial das políticas como sinônimo de política local. Essa interpretação é criticada pela autora, para a qual para uma política ser territorial deve-se considerar os fatores materiais/naturais e a organização social (político, econômica e cultural) do território.

Silva (2013) e Silva (2017) defendem que todas as políticas públicas possuem uma dimensão territorial, no entanto, com relevâncias distintas. Silva (2013) elabora quatro categorias (quadro 1) para distinguir a relação do território com as políticas públicas, sintetizadas no quadro abaixo:

Quadro 1- Território nas Políticas Públicas

\begin{tabular}{|l|l|l|l|}
\hline Categorias & Definição & Conflituosidade & Exemplos \\
\hline $\begin{array}{l}\text { Território como } \\
\text { meio }\end{array}$ & $\begin{array}{l}\text { Políticas setoriais que definem recortes territoriais } \\
\text { específicos para alcançar maior efetividade na sua } \\
\text { implementação }\end{array}$ & Baixa & $\begin{array}{l}\text { Consórcios municipais de } \\
\text { educação e de saúde; } \\
\text { UPPs; PSF }\end{array}$ \\
\hline $\begin{array}{l}\text { Território como } \\
\text { fim }\end{array}$ & $\begin{array}{l}\text { Políticas que se baseiam em estratégias intersetoriais e } \\
\text { articuladas para o desenvolvimento de territórios com } \\
\text { deficiências estruturais e alta incidência de pobreza }\end{array}$ & Média & $\begin{array}{l}\text { Política Nacional de } \\
\text { Desenvolvimento } \\
\text { Regional; CONSADs; } \\
\text { Territórios da Cidadania }\end{array}$ \\
\hline $\begin{array}{l}\text { Território como } \\
\text { regulação (ou } \\
\text { diagnóstico) }\end{array}$ & $\begin{array}{l}\text { Políticas que se utilizam de uma abordagem territorial } \\
\text { para estabelecer normatizações e/ou diagnósticos para } \\
\text { o uso público e privado de recortes territoriais } \\
\text { específicos }\end{array}$ & Média & $\begin{array}{l}\text { PNOT ; ZEE; Plano de } \\
\text { Desenvolvimento da } \\
\text { Amazônia }\end{array}$ \\
\hline $\begin{array}{l}\text { Território como } \\
\text { direito }\end{array}$ & $\begin{array}{l}\text { Políticas que visam assegurar a grupos sociais } \\
\text { específicos o direito a recursos territoriais que são } \\
\text { imprescindíveis para sua reprodução social e seu bem- } \\
\text { estar }\end{array}$ & Alta & $\begin{array}{l}\text { Reforma agrária; } \\
\text { regularização de áreas } \\
\text { quilombolas; demarcação } \\
\text { de terras indígenas }\end{array}$ \\
\hline
\end{tabular}

Fonte: Silva (2013).

Deve-se observar, entretanto, que os programas avaliados por Silva (2012) ainda apresentavam diversos entraves para uma abordagem territorial, principalmente no âmbito institucional e de uma legislação em que esteja prevista um enfoque territorial, o autor lista os seguintes entraves:

Entre os principais deles estão: a dificuldade em estabelecer programas intersetoriais inovadores; a falta de um marco jurídico mais favorável para o 
desenvolvimento de programas territoriais de desenvolvimento, onde o território e seus respectivos fóruns deliberativos ganhem maior legitimidade; a necessidade de ações diferenciadas para o empoderamento de grupos sociais invisibilizados, dada a estrutura de desigualdade social no interior dos territórios brasileiros; os mecanismos de financiamento ainda são inadequados para darem suporte a projetos territoriais estratégicos; e o desprezo de temas importantes para o desenvolvimento territorial e que, a princípio, geram sérios conflitos de interesse, como a reforma agrária e a regularização fundiária, o que leva a crer que o processo de definição de projetos territoriais ocorre apenas sob um contexto harmônico de relação entre as forças sociais presentes, desconsiderando a existência de conflitos. (SILVA, 2012, p.166).

Da mesma forma que existe para "território" diferentes graus de importância nas políticas públicas, destaca-se que, à medida que se aumenta sua preponderância, a conflituosidade se acentua (SILVA, 2013). Esta potencialidade está relacionada aos processos contraditórios do interior das instituições do Estado com relação ao território (MELLO-THÉRY, 2011b, SILVA, 2013), mas também podem ser abordados a partir da apropriação ou projetos propostos pela sociedade para o território (FERNANDES, 2015). Para se discutir estes conflitos, vale primeiramente observar que existem tipologias de conflitos, as quais alguns autores se detiveram em suas análises, como Little (2001), Torre et al. (2006), Mello-Théry (2011b) e Fernandes (2015).

Segundo Little (2001), os conflitos podem ser divididos nas seguintes categorias: 1) conflitos pelo domínio dos recursos naturais; 2) derivado dos impactos ambientais e sociais; e 3) pelos conhecimentos ambientais. Destacam-se os conflitos pelos recursos naturais que se desenvolvem sobre e pela disputa do território e podem ser ainda subdivididos em três categorias: social, político e jurídico. $\mathrm{O}$ aspecto social dos conflitos pelos recursos naturais é a disputa sobre a distribuição dos recursos pelo Estado e como este os aproveita. $\mathrm{O}$ aspecto político é referente ao acesso dos recursos, expresso em disputas destes que são bens comuns e o domínio de algum ator e a disputa sobre a distribuição dos recursos entre os atores. Por último, o aspecto jurídico diz respeito aos conflitos sobre o controle legal em razão da sobreposição das instituições na gestão do território, além dos casos da disputa pela posse formal dos recursos removidos.

Mello-Théry (2011b) demonstra os conflitos a partir das diversas instituições do Estado no território. Segundo a autora, estes conflitos decorrem da divergência e da sobreposição territorial de diversos projetos e em razão da capacidade de gestão de cada um destes entes, passando a interferir no território com o pacto federativo, que territorializou o poder destes atores. 
No âmbito da APAVRT, há conflitos de sobreposição nas políticas de ordenamento territorial entre o Estado, que define um zoneamento para o solo, e os municípios que fazem parte da APA, que também definem os seus planos diretores e seus zoneamentos. Ainda há os conflitos relativos às APAs, como Côrte (1997) verificou em diversas APAs do Brasil, com as restrições do uso do solo e as propriedades privadas, a dificuldade da participação social e os problemas de gestão das Unidades de Conservação.

O levantamento feito pelo Plano de Manejo $^{6}$ (FF, 2013) observou que, majoritariamente, os municípios seguiam o ordenamento estipulado para a APA. Sato (2013) observou, em um recorte de 3 municípios entre 12, que, ao contrastar o uso e ocupação do solo com o ordenamento territorial, o uso seguia o que estava definido pelos planos diretores e não o que estava definido pelo ordenamento de nível estadual.

Importante destacar que uma APA tem como pressuposto uma política de ordenamento territorial e um plano de manejo para o seu funcionamento. No entanto, havia uma crítica no fim dos anos 2000 de que o ordenamento da APAVRT era antigo e não existia um plano de manejo. E, como foi apontado por Bertone e Mello (2006), para a política de ordenamento territorial em nível nacional, na ausência da elaboração de uma Política de Ordenamento Territorial (PNOT), o Programa do Zoneamento Ecológico Econômico acabou assumindo o lugar de uma política nacional. De forma análoga, um entrave nos instrumentos da APAVRT alimenta um processo de evolução dos planos diretores, assim como de políticas de outras instituições, que redefinem o território e podem divergir ou impactar a longo prazo os objetivos e áreas críticas da APA.

A conflituosidade pode ser analisada como inerente aos múltiplos territórios existentes em um mesmo espaço, resultado de diversas apropriações e modelos de desenvolvimento para o território (FERNANDES, 2015). Da mesma forma, Torre et. al. (2006) colocam os conflitos a partir da disputa dos usos para o território, pois este tem diversos usos potenciais e podem ser conflitantes. No caso, os usos são organizados em três categorias: usos econômicos, de moradia e recreação, e, por último, de preservação (TORRE ET AL., 2006).

${ }^{6}$ Documento técnico, que orienta a gestão das Unidades de Conservação e exigido pelo Sistema Nacional de Unidades de Conservação (L9985/2000). Este documento começou a ser feito em 2011 e será abordado com mais profundidade nos próximos capítulos. 
Os autores apresentados nesta discussão têm como elemento em comum o aspecto territorial dos conflitos, haja vista que a apropriação, o exercício de gestão do território ou modelo a ser implementado estão em questão. Para compreender a ação de cada um dos atores governamentais, requer-se a análise das políticas públicas e seu processo.

Como modelo de análise para as políticas públicas, Klaus Frey (2000) propõe o uso da policy analysis, na qual se compreende em três níveis a política:

- a dimensão institucional "polity" se refere à ordem do sistema político, delineada pelo sistema jurídico, e à estrutura institucional do sistema político-administrativo;

- no quadro da dimensão processual "politics" tem-se em vista o processo político, freqüentemente de caráter conflituoso, no que diz respeito à imposição de objetivos, aos conteúdos e às decisões de distribuição;

- a dimensão material "policy" refere-se aos conteúdos concretos, isto é, à configuração dos programas políticos, aos problemas técnicos e ao conteúdo material das decisões políticas. (FREY, 2000, p.216-217)

Para análise da polity, verificam-se as instituições governamentais e a relação entre elas. As instituições governamentais possuem um papel importante para a elaboração de políticas pela sua capacidade de impor decisões (DYE, 2008) e para APA essas instituições possuem um papel preponderante. Considerando a polity deve-se considerar também, além do tipo e da estrutura das instituições no poder público, o modelo atual da administração gerencial implementada desde a reforma Bresser Pereira e que se sobrepõe à administração patrimonialista e à burocrática (LIMA JUNIOR, 1998).

$\mathrm{Na}$ abordagem proposta por Frey (2000) a neoinstitucional e a análise de estilos políticos têm um papel importante para a análise de políticas públicas em países de democracia não consolidada.

A análise de estilos políticos surge a partir de uma crítica da análise de políticas públicas tradicional (FREY, 2000) e é definida como:

ao mesmo tempo, levou ao surgimento de uma vertente de pesquisa que pode ser designada como análise de estilos políticos e que vem-se dedicando mais ao aspecto do como da política ('politics'), frisando fatores culturais, padrões de comportamento político e inclusive atitudes de atores políticos singulares como essenciais para compreender melhor o processo político, que, por sua vez eis um pressuposto central dessa abordagem, repercute na qualidade dos programas e projetos políticos elaborados e implementados. (FREY, 2000, p. 235) 
No campo da análise de estilos políticos, compreende-se desde o nível individual ao coletivo. Considera-se também aspectos da cultura política ou dos padrões de comportamento político, como a corrupção, o paternalismo e o clientelismo (FREY, 2000).

A proposta neo-institucional, trabalhada por Frey (2000), se relaciona com o âmbito da polity e evidencia um papel importante das instituições governamentais no processo político, no entanto, diverge de outros atores que trabalham com a Policy Analysis e utilizam as instituições em sentido mais amplo, como March e Olsen (2008) e Thoening (2010). A seguir, serão apresentadas algumas outras interpretações do papel das instituições no processo político.

March e Olsen (2008) observam a importância de se trabalhar com as instituições em razão de seu conjunto de regras e objetivos, que orientam e constrangem diversas decisões políticas. Os autores destacam que são compostas por um conjunto de pessoas que podem tomar decisões, elaborar políticas ou implementá-las com base em considerações pessoais, mas são constrangidos pelas regras. Para os autores, as instituições são dinâmicas, as quais aprendem com os processos históricos e podem mudar sua capacidade de atuação.

O modelo de polity proposto por Frey (2000) parte do pressuposto de estrutura política, recurso utilizado por estudiosos das instituições (MARCH; OLSEN, 2008):

\footnotetext{
Os estudiosos das instituições sugerem simplificações teóricas alternativas para entenderem sistemas políticos complexos, mais comumente a suposição de uma estrutura política. Por "estrutura política" queremos dizer um conjunto de instituições, regras de comportamento, normas, papéis, arranjos materiais, edificações e arquivos que são relativamente invariantes frente à rotatividade de indivíduos e relativamente resilientes às preferências e expectativas idiossincráticas dos indivíduos. Em contraste com teorias que supõem que a ação constitui-se em escolha baseada nos valores de indivíduos, as teorias da estrutura política supõem que a ação constitui-se no cumprimento de deveres e de obrigações. (...). Em uma metáfora do dever, supomos que os atores políticos associam certas ações com certas situações por meio de regras de adequação. O que é adequado para uma pessoa particular em uma situação particular é definido pelo sistema político e social e transmitido por meio da socialização. (MARCH; OLSEN, 2008, p.129-130, grifo nosso)
}

A partir destas definições, o Estado aparece como um conjunto de instituições que podem cooperar ou competir entre si (FREY, 2000; MARCH; OLSEN, 2008; THOENING, 2010) e a relação entre os órgãos é assimétrica (THOENING, 2010). Com referência aos temas ambientais, estes conflitos e assimetrias de poder são evidenciados 
por Mello-Théry (2011b), a Amazônia com relação ao órgão ambiental, os de infraestrutura, e os de política agrária.

Para Thoening (2010), as organizações não são instrumentos passivos e ganham um papel ativo e de defesa de sua automanutenção e de seus interesses; e uma institucionalização sólida é definida como:

Conquista-se uma institucionalização sólida quando algumas regras e procedimentos são considerados invioláveis; quando algumas unidades, ou membros de um órgão público, se tornam centros de poder semiautônomos e desenvolvem interesses próprios garantidos; e quando existem rituais, símbolos e ideologias administrativas. Expectativas, comportamentos e crenças são direcionados e estabilizados. (THOENING, 2010, p.172)

A contribuição de Klaus Frey (2000) e de um novo institucionalismo (THOENING, 2010) é pensar uma relação de interdependência entre a polity, politics e policys. Devese ter a cautela para não interpretar as instituições como fator único determinante do comportamento dos indivíduos e da burocracia. Massardier (2003) verifica que em uma análise mais detalhada das instituições públicas existe um ajustamento, adaptação ou subversão de algumas regras e procedimentos de acordo com o interesse de alguns atores. Da mesma maneira, Marques (2003), ao estudar a política de infraestrutura de São Paulo, verificou diversas redes de atores mobilizando o ciclo de políticas públicas de acordo com interesses próprios ou afinidades políticas. Pode-se, para a análise, dividir o governo e as instituições nos diferentes grupos, como os políticos do legislativo, o executivo (presidente, secretários, governador, etc.) e os grupos técnicos de assessores e burocratas, os quais podem colaborar, monopolizar ou competir pela definição das políticas (CAHN, 1995; MARQUES, 2003).

$\mathrm{O}$ enfoque neoinstitucional apresenta também interpretações muito distintas nos campos da ciência política, da administração pública, da economia e da sociologia, os quais trazem compreensões distintas do que é a instituição e como interferem no comportamento humano (GREIF; KINGSTON, 2011).

A abordagem institucional é ampla no sentido que pode:

Comparada ao institucionalismo histórico, a perspectiva sociológica define o que significa institucional em um amplo espectro. Além de regras e procedimentos formais, ela inclui símbolos, modelos morais e esquemas cognitivos. As instituições que fornecem as estruturas de significado, que guiam as ações humanas, são semelhantes a sistemas culturais. Influenciam a conduta da administração pública, não apenas declarando o que deve ser feito - quando, onde e como -, mas também moldando a imaginação dos atores sobre 
alternativas e soluções em novos contextos. A sociedade e a cultura como um todo moldam os atos e os não atos, as estruturas e os valores do setor público. De alguma maneira, a ação opera sem atores específicos. (THOENING, 2010, p.173)

Há leituras mais amplas, em que as instituições compreenderiam desde regras, leis, comportamentos até as organizações. Para esta pesquisa, o foco está no planejamento e nas políticas públicas elaboradas pelas diferentes instituições governamentais, o que se aproxima mais da abordagem trabalhada por Klaus Frey (2000). Para tanto, é importante identificar e qualificar as instituições governamentais que interferem no território como Silva (2017).

\section{3 - Procedimentos de Pesquisa}

O procedimento inicial utilizado foi a revisão bibliográfica sobre território e políticas públicas, com o fim de realizar as análises a partir da Policy Analysis políticos (FREY, 2000), e a investigação a partir do sistema territorial, com base no modelo de Raffestin (2012; 2015), existente na região da APA da Várzea do Rio Tietê. Em seguida, foi realizada a análise dos documentos existentes das diferentes políticas territoriais que se sobrepõem à APA VRT, visitas técnicas e leitura das atas das reuniões para acompanhar a tomada de decisões dessas políticas e o processo de participação. Este material foi obtido, em parte, nos sites oficiais e outra parte considerável a partir de indicações ou diretamente com pessoas envolvidas nessas políticas.

Foram realizadas atividades de campo com observação participante para o reconhecimento dos principais atores, compreender as arenas de decisão das políticas examinadas e poder acompanhar as esferas de governança. A observação participante pode ser definida como a participação dos fenômenos estudados e pautada pela observação (VENTURI, 2011; LAURIER, 2012). Para uma maior eficácia, é importante que seja permitida a participação no grupo estudado, assim como um conhecimento mínimo para poder compreender melhor o que se está analisando (LAURIER, 2012).

A observação participante foi realizada nas reuniões do CONSEMA, nas oficinas participativas do Plano de Bacia Hidrográfica do Alto Tietê, nas reuniões técnicas do Plano de Desenvolvimento Urbano Integrado (PDUI) e em uma das audiências públicas do PDUI e da SABESP. No entanto, dado o recorte temporal da pesquisa e dos processos políticos, também foram realizadas a análise de atas e registro das reuniões do CONSEMA e do Conselho Gestor da APA. 
Outro importante recurso é a análise espacial para fazer as análises, comparar e verificar a sobreposição e conflitos no território da APA. A análise espacial se fundamenta na correlação de fenômenos ou dados com o espaço, procurando identificar padrões de dependência e interações gerando representações gráficas como gráficos e mapas (CÂMARA ET AL., 2004). A presente análise teve como suporte os Sistemas de Informação Geográfica, sistema computacional que permite um usuário gerar, processar e/ou armazenar dados georreferenciados (CÂMARA ET AL. 2004). As operações de análise espacial recorrem ao ferramental do software livre de Sistema de Informações Geográficas QGIS, funções de recorte, overlay, intersecção, cálculo de área e mapeamentos (MAANTAY; ZIEGLER, 2006), sobrepondo os diversos planos e projetos analisados com a APA da Várzea do Rio Tietê.

A partir do referencial teórico e dos procedimentos, foram analisadas as diferentes políticas públicas que incidem no território da APA nas três dimensões (polity, politics e policy) da análise de políticas públicas, com aspectos relativos à abordagem neoinstitucional e em menor grau os estilos políticos. A dimensão das políticas públicas foi analisada temporalmente considerando o ciclo de políticas públicas e territorialmente. A análise também foi orientada pelas variáveis propostas pelo modelo de Raffestin (2012; 2015), procurando atentar para as variáveis elencadas, a interação destas e o reflexo no território. 


\section{2- São Paulo, Metrópole e rio Tietê}

Neste capítulo será apresentado um breve histórico sobre a relação entre a cidade de São Paulo, inicialmente, e depois a região metropolitana, com o rio Tietê. Essa relação será abordada no próximo tópico como fator importante para a criação da APA VRT.

O rio Tietê e sua planície de inundação foram historicamente marcados por diversos usos e apropriações pelas populações residentes e, posteriormente, pelos municípios e para múltiplos usos. O Tietê do ponto de vista da historiografia paulista foi tema de diversos debates do Instituto Histórico e Geográfico de São Paulo, como caminho dos Bandeirantes para a expansão territorial do Brasil (DINIZ, 2013). Segundo Diniz (2013), esses debates históricos mobilizaram autores como Affonso de Taunay, Cassiano Ricardo, Capistrano de Abreu, Caio Prado Júnior, Sérgio Buarque de Holanda, Ellis Júnior e Humberto Mello Nóbrega. Taunay defendia o rio Tietê como a principal via do bandeirantismo e a ocupação territorial do Brasil (DINIZ, 2013).

De modo geral, o Rio Tietê figurou como elemento essencial para a expansão territorial brasileira, a despeito da oposição de Sérgio Buarque de Holanda e de Ellis Junior (DINIZ, 2013). Segundo Diniz, o rio Tietê ainda seria retomado pela historiografia contemporânea a partir de uma perspectiva ambiental com Dora Shellard Corrêa e Zuleika M. F. Alvim, Janes Jorge (2011), Denise Bernuzzi de Sant'Annae Alexandre Rodrigo dos Santos (2011). Desses debates históricos foram escolhidos os autores com uma perspectiva ambiental para a caracterização do rio Tietê, além de outras importantes contribuições de historiadores, geógrafas, arquitetos e urbanistas.

Inicialmente, o rio Tietê era ocupado por comunidades de povos originários, os quais dependiam do rio para subsistência (ZAGNI, 2004; ZANIRATO, 2011; FF, 2013). De modo geral na literatura, os rios vão ser importantes para a ocupação inicial da cidade de São Paulo, pela facilidade de obtenção de água e alimento, mas também por questões estratégicas de defesa (CAMARGO, 2006, MOROZ CACCIA-GOUVEIA, 2016). O sítio inicial da ocupação foi sobre o assentamento de povos originários e vai ser em torno dos rios Tamanduateí, Anhangabaú e a várzea do Carmo, que propiciaria uma vantagem estratégica, e posteriormente o rio Tamanduateí, ao ligar-se o rio Tietê, permitiria as navegações para o interior (ZAGNI, 2004; SANTOS, 2011).

De modo geral, a ocupação colonial não mudaria muito até o século XIX, período em que começa a expansão urbana e há uma mudança de paradigma com relação aos rios, 
os quais se tornaram obstáculos e focos de doenças (SANTOS, 2011; JORGE, 2011, 2012; 2017).

Diversas atividades se desenvolveram no entorno do rio Tietê, como a extração de argila e a mineração de areia (para a construção civil), aterramentos, agricultura, lazer nas margens do rio, instalação de atividades industriais, obras para aproveitamento energético, construção de moradias. O rio também passou por obras hidráulicas, como de retificação e represamento e, inclusive, tornou-se canal de despejo de efluentes (SEABRA, 1987; ZANIRATO, 2011; FF, 2013; RODRIGUES, 2015; JORGE, 2017). Todas essas atividades não ocorreram de maneira contínua ao longo do rio, elas se distribuíram de maneira distinta por ele, como as obras hidráulicas, que estão concentradas na área do município de São Paulo, e outras que eram comuns aos demais municípios como Mogi das Cruzes, Suzano, Itaquaquecetuba etc.

A partir de 1890, com a mudança de paradigma com relação ao rio Tietê, os problemas da contaminação do rio e as propostas higienistas ganhavam espaço e a retificação do rio Tietê entrou na agenda com esses argumentos (SANTOS, 2011). Os projetos de retificação tinham como objetivo combater as inundações, o problema de esgoto e "embelezar" o rio (SANTOS, 2011). As obras foram iniciadas em 1937 e concluídas na década de 1960, com a retificação do trecho entre São Paulo e Osasco e a construção da barragem da Penha para o controle das cheias (ZANIRATO, 2011).

O quadro 2, abaixo, apresenta as diversas etapas e os projetos de retificação do rio Tietê. Cada projeto proposto apresentava extensões e soluções distintas para regular o regime hídrico. 
Quadro 2 - Principais propostas e etapas da retificação do rio Tietê

\begin{tabular}{|c|c|}
\hline 1890 & $\begin{array}{l}\text { Criação da Comissão de Saneamento das Várzeas chefiada por Theodoro Sampaio e Antônio de } \\
\text { Paula Souza }\end{array}$ \\
\hline 1892 & Comissão de Saneamento do Estado chefiada por João Pereira Ferraz \\
\hline 1893 & Encomenda-se o projeto para o rio Tietê ao Eng. João Pereira Ferraz \\
\hline 1894 & Estudos para retificação do rio Tietê \\
\hline 1898 & Fim da Comissão de Melhoramentos do Rio Tietê \\
\hline 1911 & Tentativa de retomada da Comissão \\
\hline 1913 & Plano Geral de Melhoramentos para o Tietê de Osvaldo Pacheco e Silva \\
\hline 1922 & Projeto de José Fonseca Rodrigues de retificação do rio \\
\hline $\begin{array}{l}\text { 1923- } \\
1924\end{array}$ & Retomada a Comissão com o Eng. Saturnino de Brito \\
\hline $\begin{array}{l}\text { 1925- } \\
1926\end{array}$ & Projeto de Melhoramentos do Rio Tietê desenvolvido por Saturnino de Brito \\
\hline 1926 & Extinção da Comissão \\
\hline 1926 & Projeto Serra de Asa Billings \\
\hline 1927 & Nova Comissão chefiada pelo Ulhôa Cintra \\
\hline 1928 & $\begin{array}{l}\text { Novo projeto com base no projeto de Saturnino de Brito e no Plano de Avenidas de Prestes } \\
\text { Maia }\end{array}$ \\
\hline 1930 & Plano de Avenidas de Prestes Maia e Ulhôa Cintra \\
\hline 1937 & Restituída a Comissão com Ulhôa Cintra \\
\hline 1937 & Início da retificação do Rio Tietê \\
\hline 1938 & Fim da comissão e criação da Divisão de Rios e Águas Pluviais \\
\hline 1945 & Retomada a Comissão de Melhoramentos do Rio Tietê e Tamanduateí \\
\hline 1951 & Programa de Melhoramentos Públicos para a cidade de São Paulo de Robert Moses \\
\hline 1960s & Conclusão da Retificação do rio Tietê \\
\hline
\end{tabular}

Fonte: Elaborado pelo autor com base em Delijaicov (1998), Monteiro (2010),Santos (2011) e Santos (2014).

Embora nos projetos de Saturnino de Brito e de Ulhôa Cintra existisse a preocupação do represamento e de reservatórios para evitar problemas com as inundações, estes não foram executados em razão da atuação da São Paulo Tramway Lightand Power Company Limited, também conhecida como Light (SANTOS, 2011).

As diversas propostas de retificação do rio Tietê e o resultado final evidenciam os conflitos territoriais e de poder entre os diferentes atores, que projetaram diferentes alternativas em tensão entre si e com os interesses da Light, empresa a qual foi 
documentada nas diferentes teses e livros $^{7}$, ter um grande poder de influência territorial. Outro fator importante para os processos de decisão e de alternativas para a execução dos projetos e de obras viárias foi a figura de Prestes Maia durante a sua gestão, que influenciaria por 40 anos as obras viárias do município de São Paulo como prefeito (PETRONE, 1955; MARQUES, 2003).

No esquema abaixo, na figura 2, elaborado por Santos (2014) está representado o processo de retificação do rio Tietê, que se efetivou a partir da década de 1930 e vai prosseguir com a expansão urbana (área hachurada).

Figura 2 - Retificação do rio Tietê

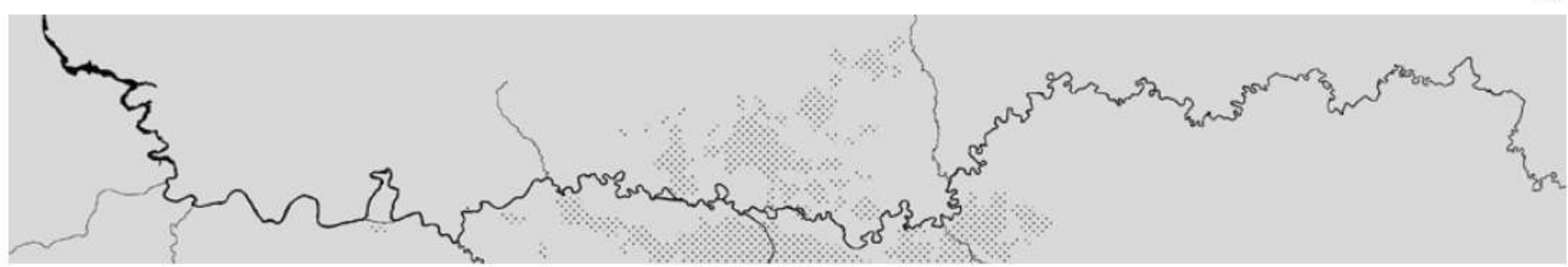

1960

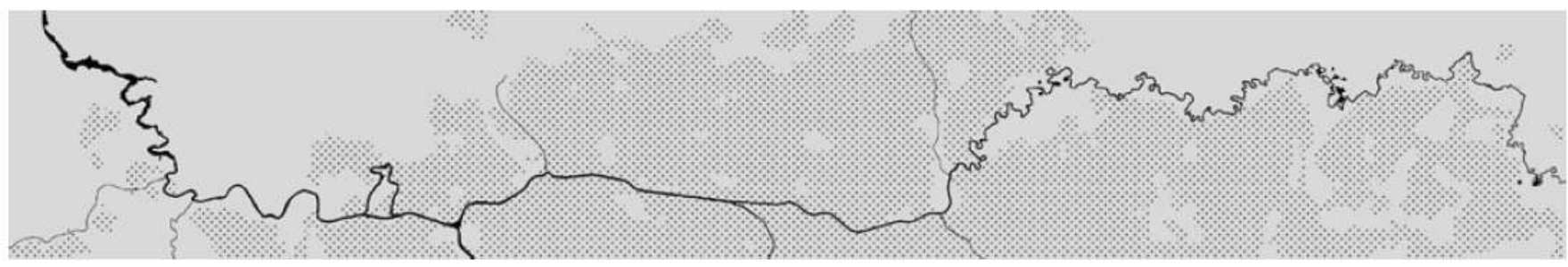

1990
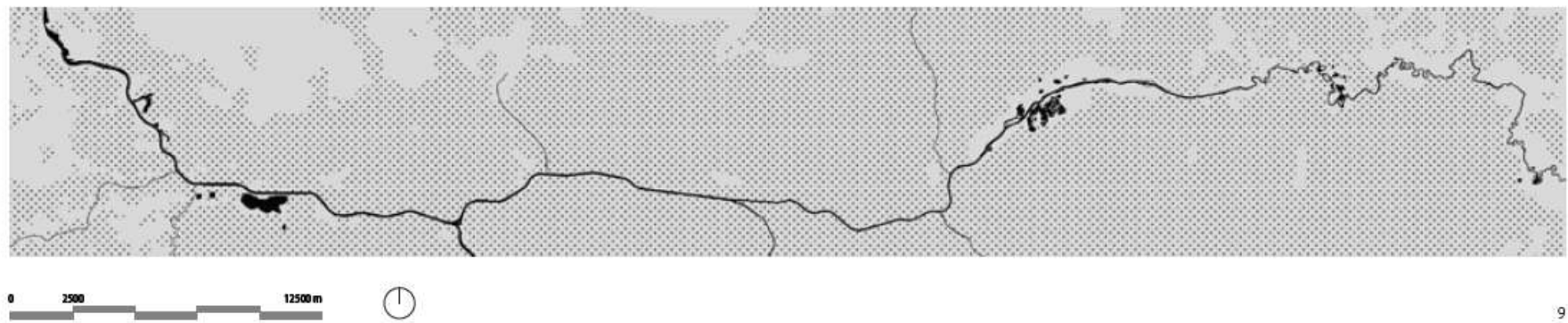

Fonte: Franco (2005).

A retificação do rio Tietê, assim como de outros importantes rios, como o Pinheiros e o Tamanduateí, está associada à utilização das várzeas para as obras de infraestrutura

${ }^{7} \mathrm{Na}$ literatura autores como Seabra (1987), Franco (2005) Santos (2011) comentam do papel da Light nesse processo. No entanto é importante destacar que tanto Franco (2005) como Santos (2011) se basearam na tese da Odette Seabra (1987) com relação a esse fato. 
de nível regional e metropolitano, além dos interesses imobiliários que também existiam (SEABRA, 1987; FRANCO, 2005). No século XX, as linhas ferroviárias, seriam importantes vetores da ocupação das planícies de inundação, aproveitando os vales e áreas de pouco interesse imobiliário se instalaram próximas aos rios e induziram a instalação de fábricas e a formação de bairros operários nas planícies de inundação (PETRONE, 1955). Exemplos dos rios Tamanduateí associado a São Paulo Railway e a expansão do parque industrial nesse eixo; o rio Pinheiros com a reversão para a hidrelétrica Edgard de Souza; e o rio Tietê com a construção da Marginal Tietê (SEABRA, 1987; FRANCO, 2005).

Destacam-se, além da retificação do rio, os planos viários e as obras hidráulicas que interferiram nos processos do rio Tietê. Diversos estudos são relevantes tratando dos efeitos da urbanização, dessas interferências no rio Tietê e os impactos associados. Esses estudos do campo da geomorfologia e da hidrologia, contudo, não serão abordados com a devida profundidade, pois não é o foco da presente pesquisa. Menciona-se brevemente que nesses estudos as dinâmicas da ocupação e da urbanização interferem nos processos geomorfológicos (RODRIGUES, 2004; ROSS, 2004), impactando, no caso do rio Tietê, em problemas de perda de área das planícies de inundação e, consequentemente, capacidade de retenção das águas das inundações, além da impermeabilização. O padrão da urbanização tem uma série de impactos, mas destaca-se a impermeabilização e as ilhas de calor. A impermeabilização contribui para o maior fluxo de escoamento superficial da água e intensificando-se a descarga de água nos rios, provocam-se picos de cheias maiores ou mesmo inundações (TUCCI, 2007). Do ponto de vista do clima, o padrão de urbanização contribui para a formação de ilhas de calor, que se caracterizam pelo aumento artificial do calor nas áreas urbanas com relação às áreas rurais ou naturais em razão dos tipos de materiais utilizados na cidade que retêm mais calor (GARTLAND, 2010).

As ações e as alternativas para conter e resolver os problemas também são cruciais de serem analisadas. Tucci $(2003 ; 2007 ; 2008)$ critica os modelos adotados no Brasil, que seriam correspondentes ao modelo Higienista, na classificação do autor. Paradigma do início do século XX, a década de 1970 foi marcada pela coleta de esgoto com um baixo tratamento, pelas soluções técnicas para o escoamento rápido das águas urbanas e pelas grandes obras de infraestruturas, como os famosos piscinões.

Haja vista o processo de urbanização, as soluções técnicas, a ocupação e impermeabilização das planícies de inundação e vales estreitos, o regime de chuvas com períodos concentrados, o estrangulamento dos leitos (menor e maior) dos rios, o 
assoreamento e o sistema de drenagem com acúmulo de lixo implicam em uma série de problemas de inundações e sua intensificação (RODRIGUES, 2004; ROSS; 2004). Essa intensificação está explícita na tabela 1 abaixo. Esse processo de aumento de enchentes é um dos fatores que implicou na criação da APAVRT.

\begin{tabular}{l} 
Tabela 1- Evolução dos pontos críticos de inundações no município de São Paulo. \\
$\qquad$\begin{tabular}{|c|c|c|}
\hline Período & No de pontos críticos & Acréscimo (\%) \\
\hline $1978 / 79$ & 125 & - \\
\hline $1979 / 80$ & 147 & 17.6 \\
\hline $1980 / 81$ & 185 & 25.85 \\
\hline $1981 / 82$ & 246 & 32.97 \\
\hline 1991 & 420 & 70.74 \\
\hline
\end{tabular} \\
\hline
\end{tabular}

No entanto, a despeito da APA ser criada em 1987, o número de pontos críticos continuou aumentando. Scatena (2015) observa que a APA seria inoperante até 1998 e haveria um grande crescimento urbano nos municípios que contêm a APA, além da execução de projetos habitacionais e ocupações no entorno do rio Tietê nesse período.

Esses problemas de inundações se acentuaram após os anos 1960, momento em que se intensificou a impermeabilização, obras viárias e a formação de ilhas de calor pela baixa arborização, segundo Cabral e Jesus (1994).

Outros projetos importantes que iriam intensificar esses efeitos foram as Avenidas de Fundo de Vale de 1975, Programa de Canalização de Córregos, Implantações de Vias de Fundo Vale de São Paulo de 1986/87, o Grupo Executivo dos Programas de Canalização de Córregos, Implantação de Vias e Recuperação Ambiental e Social de Fundos de Vale de 1994 (DELIJAICOV, 1998).

Todos esses processos de retificação do rio Tietê e das obras para uso de suas áreas de várzeas, além das diversas obras de infraestrutura nos rios da cidade e a impermeabilização dos solos, intensificaram os problemas de inundação na cidade. No mapa abaixo (fig. 3) está sintetizado o crescimento urbano do fim do século XIX e do século XX. Nota-se que houve uma grande expansão urbana, visível pelos diferentes tons de cinza e preto, que representam o crescimento urbano de 1881 até 2005 . Nesse mapa, os rios têm três representações, sendo que os rios em azul são os que mantêm o curso natural, em vermelho são os rios encanados e em amarelo os rios canalizados/retificados. De modo geral, os rios na área urbana foram alterados ao longo do século XX pelas obras de "modernização", com os diversos estudos, planos e projetos em que vários rios vão ser 
transformados, canalizados ou enterrados (SEABRA, 1987; SANTOS, 2011). Os pontos em vermelho são os locais de alagamento de novembro de 2016 a março de 2017, os quais se concentram no entorno dos rios canalizados, com destaque para o rio Tietê. 
Figura 3 - Mapa da expansão urbana e os rios urbanos

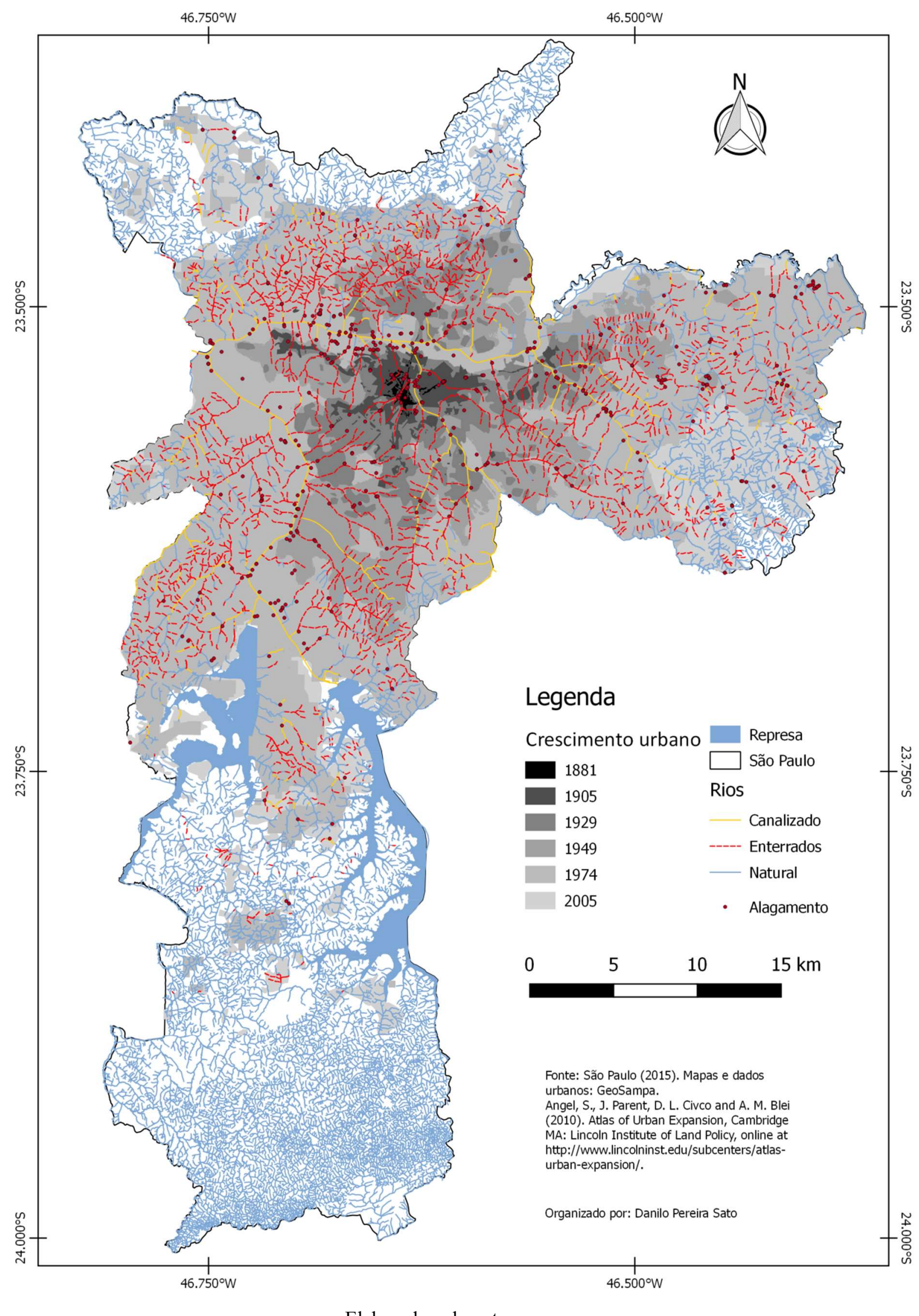

Elaborado pelo autor 
Os impactos e os problemas relacionados à ocupação das várzeas e às inundações suscitou diversas propostas de soluções urbanísticas, elaboradas por arquitetos, urbanistas e paisagistas como o Jorge Wilheim com José Cordeiro em 1967, Cândido Malta Campos Filho em 1973, Ruy Ohtake com Burle Marx e sua equipe (resultou no Parque Ecológico do Tietê) em 1977, Paulo Mendes da Rocha em 1980, Oscar Niemeyer e sua equipe em 1986, Décio Tozzi em 1988, Marcos Acayaba em 1993, Roberto Loeb em 1990, Bruno Padovano em 1998. Suscitou também várias teses e dissertações com propostas de intervenção para o rio Tietê, como de Alexandre Delijaicov (base do projeto do Hidroanel) em 1998, Denise Falcão Pessoa em 2006 e Brocaneli em 2007 (DELIJAICOV, 1998; FRANCO, 2005; PESSOA, 2006; BROCANELI, 2007; MONTEIRO, 2010).

Vários desses projetos vão ser criticados por Pessoa (2006) por manterem o paradgima da retificação do rio Tietê. Poucas exceções vão pensar além da retificação e propor alternativas. Por outro lado, os projetos mais recentes consideram a recuperação das planícies de inundação parcial ou integralmente com a renaturalização dos rios como Padovano (1998), Pessoa (2006) e Brocaneli (2007).

A partir desse subtópico se verifica o rio Tietê, desde o fim do século XIX, se inseriu como um problema na agenda política e alvo de diversos projetos e alternativas técnicas para solucionar aspectos da dinâmica fluvial e impactos da urbanização. Esses impactos e problemas estão associados à urbanização de São Paulo e da Região Metropolitana e das características geomorfológicas e hídricas do rio Tietê. Outra resposta importante, de âmbito metropolitano e que considera os aspectos físicos do rio Tietê, será a criação da APA da Várzea do Rio Tietê, em 1987, para conter o avanço da ocupação das várzeas e atenuar os problemas relacionados as inundações.

\section{1 - APA da Várzea do Rio Tietê: contexto histórico, processos políticos e território}

A APA da Várzea do Rio Tietê é uma Unidades de Conservação de Uso Sustentável, um dos instrumentos previstos pela Política Nacional de Meio Ambiente (L6938/81). Atualmente é regulamentada pelo Sistema Nacional de Unidades de Conservação (L9985/2000) e é uma tipologia de área protegida que permite as atividades humanas, contanto que se atenda a critérios de sustentabilidade ambiental, social e econômica. Como são permitidas diversas atividades econômicas e a ocupação humana nas APAs, normalmente há poucos conflitos na criação desse tipo de UC, pois não são 
necessárias desapropriações, o que geralmente diminui os custos e conflitos para o poder público (SILVA 2006).

A origem da APAVRT está associada com o regime do rio Tietê e a ocupação de seu entorno. Sua origem remonta ao Projeto de Lei 334/1984, apresentado na Assembleia Legislativa do Estado de São Paulo, pelo então deputado estadual Walter Lazzarini.

A APA abrange 12 municípios $^{8}$, segundo o seu decreto de criação, como pode ser observado na fig. 4. Trata-se de uma APA estreita e longa, pois sua área é definida pela planície de inundação do rio Tietê. Note-se que o território da APA é dividido em dois setores: um a oeste de São Paulo e outro a Leste, a partir da barragem da Penha. A área de São Paulo que não faz parte da APA corresponde à área da marginal Tietê.

Figura 4 - Área da APAVRT e municípios.

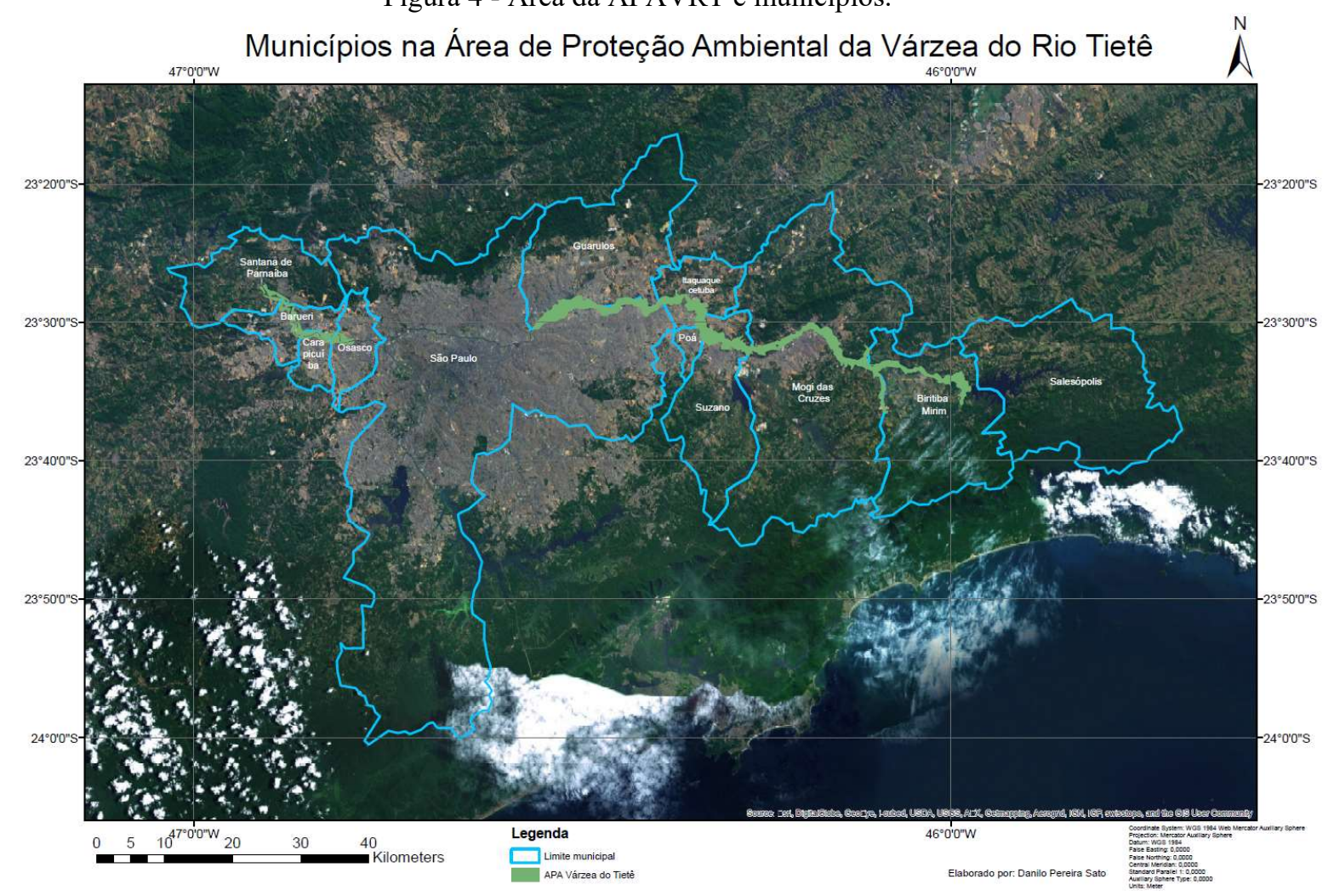

Fonte: Sato (2013)

${ }^{8}$ No decreto consta 12 municípios, no entanto a área da APA delimitada posteriormente se restringe a 11 municípios. O município que consta no decreto de criação e não tem sua área intersectada pela APA é o de Salesópolis. 
A UC foi criada para atenuar os efeitos dos processos do crescimento urbano e a ocupação das várzeas do Tietê, que intensificaram as enchentes, além da perda da qualidade ambiental (SÃO PAULO, 1984). A APA VRT foi criada em 1987, porém seria regulamentada somente em 1993 pelo decreto estadual $n^{\circ} 37619$, de 06 de outubro de 1993, o qual foi revogado e substituído pelo decreto estadual 42.837, de 03 de fevereiro de 1998. Criada com 4 objetivos: o primeiro de proteger e recuperar as margens do rio Tietê; o segundo de controlar a ocupação no entorno das margens para reduzir as enchentes ${ }^{9}$; o terceiro de minimizar a erosão e o assoreamento do rio decorrentes da urbanização; e, por fim, preservar e recuperar os remanescentes da biota (SÃO PAULO, 1993, 1998).

Com exceção do quarto objetivo, os demais procuram mitigar os problemas das inundações, que são consequência da dinâmica natural em relação com o processo de territorialização. Segundo a interpretação de Zanirato (2011), a APA tem como objetivo o controle das cheias no Setor Leste enquanto no Setor Oeste a sua função seria de manter o Parque Tamboré. O problema das enchentes ${ }^{10}$ a nível Estadual foi avaliado pela Agência Nacional de Águas (ANA), sobre a vulnerabilidade ${ }^{11}$ relacionada às inundações. No seguinte mapa (fig.5) realizou-se uma sobreposição das áreas de inundações, as quais foram contrapostas com a área da APAVRT. Evidencia-se que, na área urbana, a vulnerabilidade à inundação é maior e a área da APA se encontra, em sua maior parte, na área urbanizada, consequentemente é uma região crítica do ponto de vista das inundações. No entanto, também se destaca o trecho entre os setores Oeste e Leste da APA ser de alta vulnerabilidade. Em razão desses fatores e de não haver uma mudança no padrão de uso e ocupação do solo que se ressalta a importância da APA como forma de controle das inundações, além da proteção biológica.

\footnotetext{
${ }^{9} \mathrm{Na}$ redação do D42837/1998 consta o termo “enchente". O termo mais adequado é "inundação", pois "enchente" se refere ao aumento da vazão que implica no aumento nível da água no rio, enquanto "inundação" se refere ao extravasamento da água para o leito maior do rio (MC;IPT, 2007).

${ }^{10}$ Base de dados em Shapefile de 2014 da ANA.

11 A vulnerabilidade é classificada pela ANA (2013) de acordo com a frequência e com os impactos socioeconômicos. A classificação é alta para situações de alto impacto de qualquer frequência e médio impacto com frequência alta. A vulnerabilidade média é para situações de médio impacto com frequência média ou baixa e para situações de baixo impacto e alta frequência. E, finalmente, a vulnerabilidade baixa é para situações de baixo impacto e baixa frequência.
} 
Figura 5 - Trechos de inundação com relação à APAVRT e a área urbanizada.

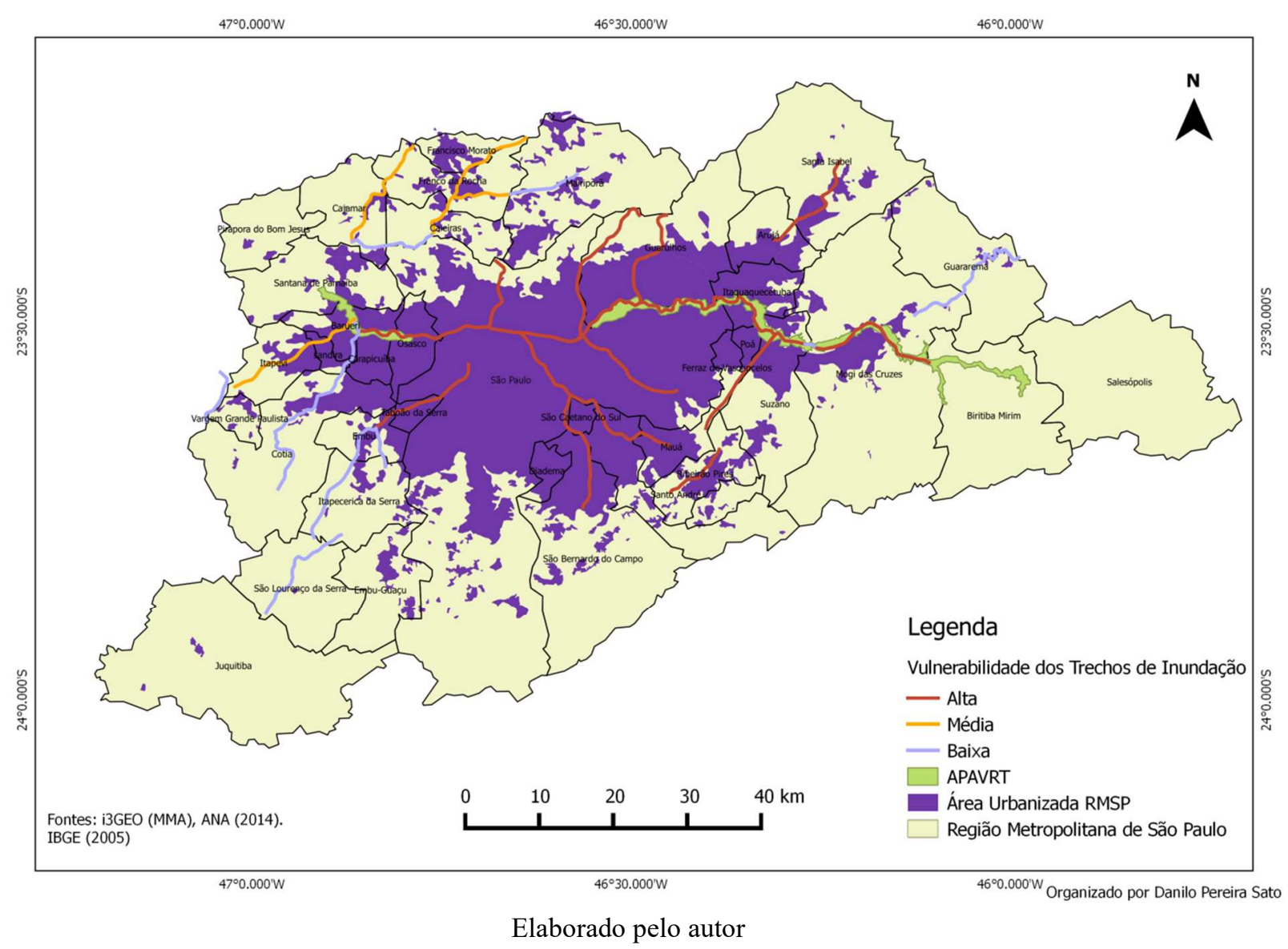

O zoneamento vigente da APA foi definido pelo D42837/1998, que estabeleceu três zonas: de Vida Silvestre (ZVS), de Cinturão Meândrico (ZCM) e Uso Controlado (ZUC). No mapa abaixo, que estão espacializadas os zoneamentos da APA, foi feito a partir do shapefile utilizado durante a elaboração do plano de manejo e disponibilizado para esta pesquisa por um dos técnicos do plano. 
Figura 6 - Mapa do Zoneamento vigente da APA da Várzea do Rio Tietê

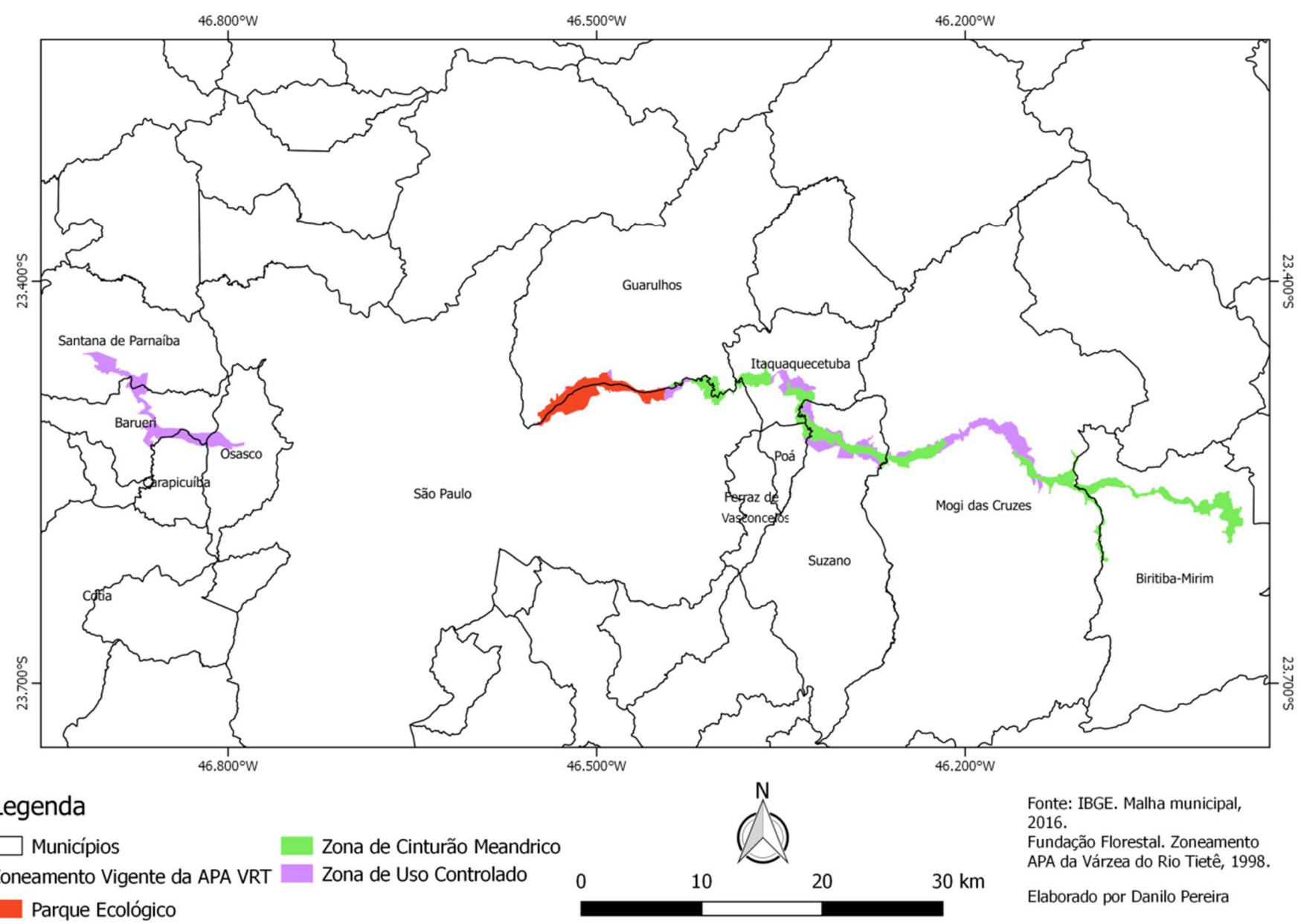

Elaborado pelo autor 
Destaca-se primeiramente, que tanto no shapefile disponibilizado, como nos mapas anexados ao decreto no Diário Oficial do Estado, não estão delimitadas as Zonas de Vida Silvestre. No texto do decreto a ZVS, corresponde às Áreas de Proteção Permanente (APP) do Código Florestal de 1965 e pelas áreas de preservação da Mata Atlântica (D750/1993). Outro elemento que se destaca no shapefile e nos mapas do decreto é a delimitação do Parque Ecológico do Tietê, que é administrado pelo Departamento de Águas e Energia Elétrica (DAEE) e que corresponde a 1374,54 ha ou 15\% do território da APA.

Atualmente o território da APA e seu entorno é aproveitado pela agricultura para a irrigação na região dos municípios de Biritiba Mirim e Mogi das Cruzes, seguida das atividades de extração de areia de Mogi das Cruzes a Itaquaquecetuba, para se tornar despejo de efluentes ao longo dos diversos municípios da Região Metropolitana de São Paulo (RMSP) (FF, 2013). Como desafio, a APAVRT enfrenta problemas elencados por Silva et al. (2014):

\footnotetext{
Este território enfrenta um processo evolutivo de ocupações irregulares, que resulta em desmatamentos, na criação de depósitos clandestinos de resíduos, de loteamentos clandestinos. Por outro lado, ocupações regulares, seja via obras públicas municipais ou estaduais, seja via obras da iniciativa privada autorizadas pelo poder público, ou ainda via ocupações inicialmente irregulares e posteriormente regularizadas pelo poder público, também contribuem com a perda das características do atributo natural, que seria a própria várzea do rio Tietê, objeto de conservação desta unidade. (SILVA ET. AL., 2014, p.244)
}

$\mathrm{Na}$ RMSP, foram perdidos $90 \%$ da área das planícies de inundação e a maior parte dos 10\% remanescentes se encontram na região leste da RMSP inseridos na APAVRT (RODRIGUES, 2015). Essa condição pode ser observada nos mapas abaixo (fig. 7 e 8). Os mapas são um comparativo do setor oeste e leste com referências aos anos de 2002 (base elaborada pela EMPLASA) e de 2007 (com base na comparação ao uso de 2002 com ortofotos de 2007) elaborados para o Plano de Manejo da APAVRT de 2013. 
Figura 7 - APA e buffer de $1 \mathrm{~km}$ trecho Oeste

Uso do solo no entorno da APA da Várzea do Tietê em 2002 e 2007 [setor oeste]

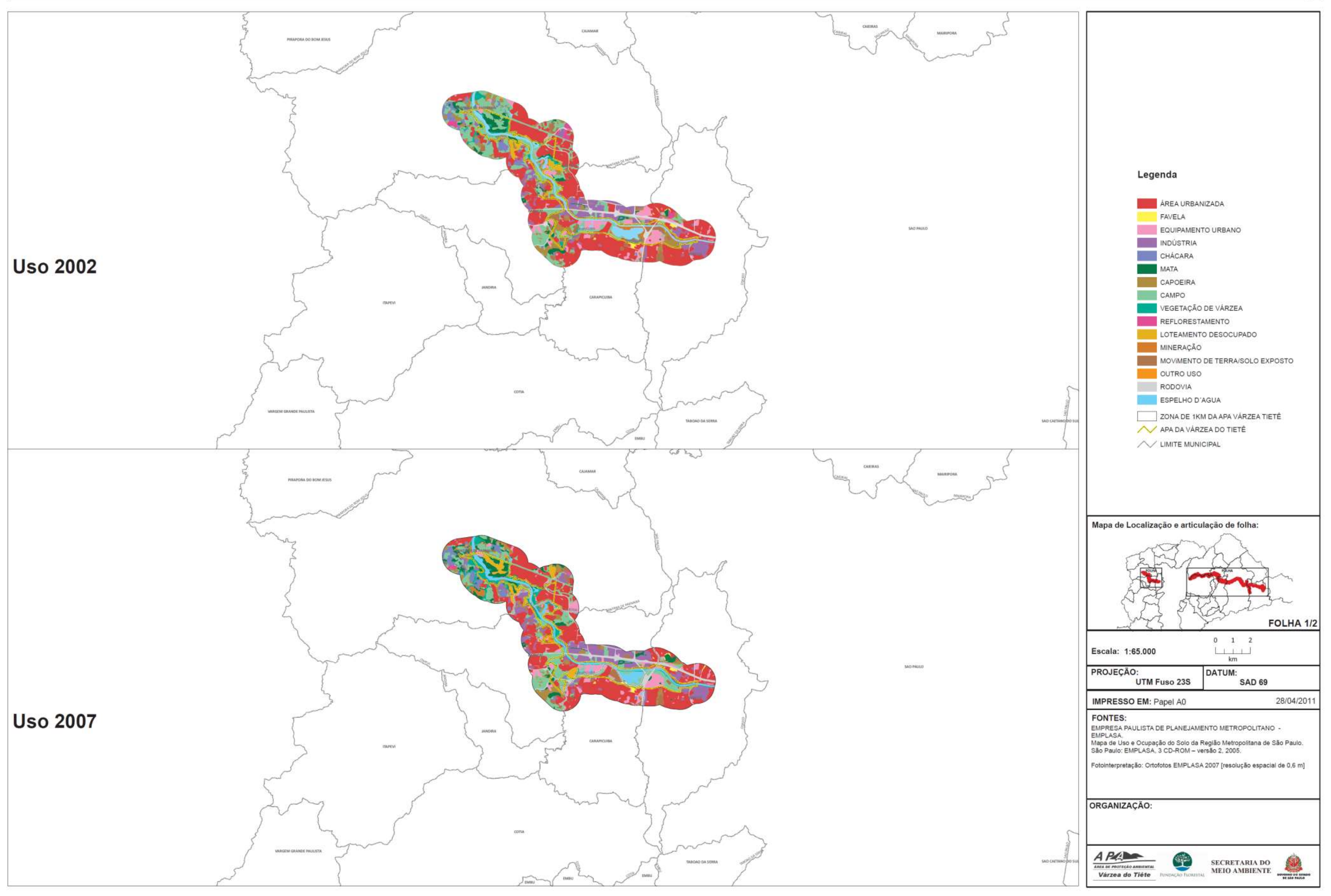

Fonte: FF (2013) 


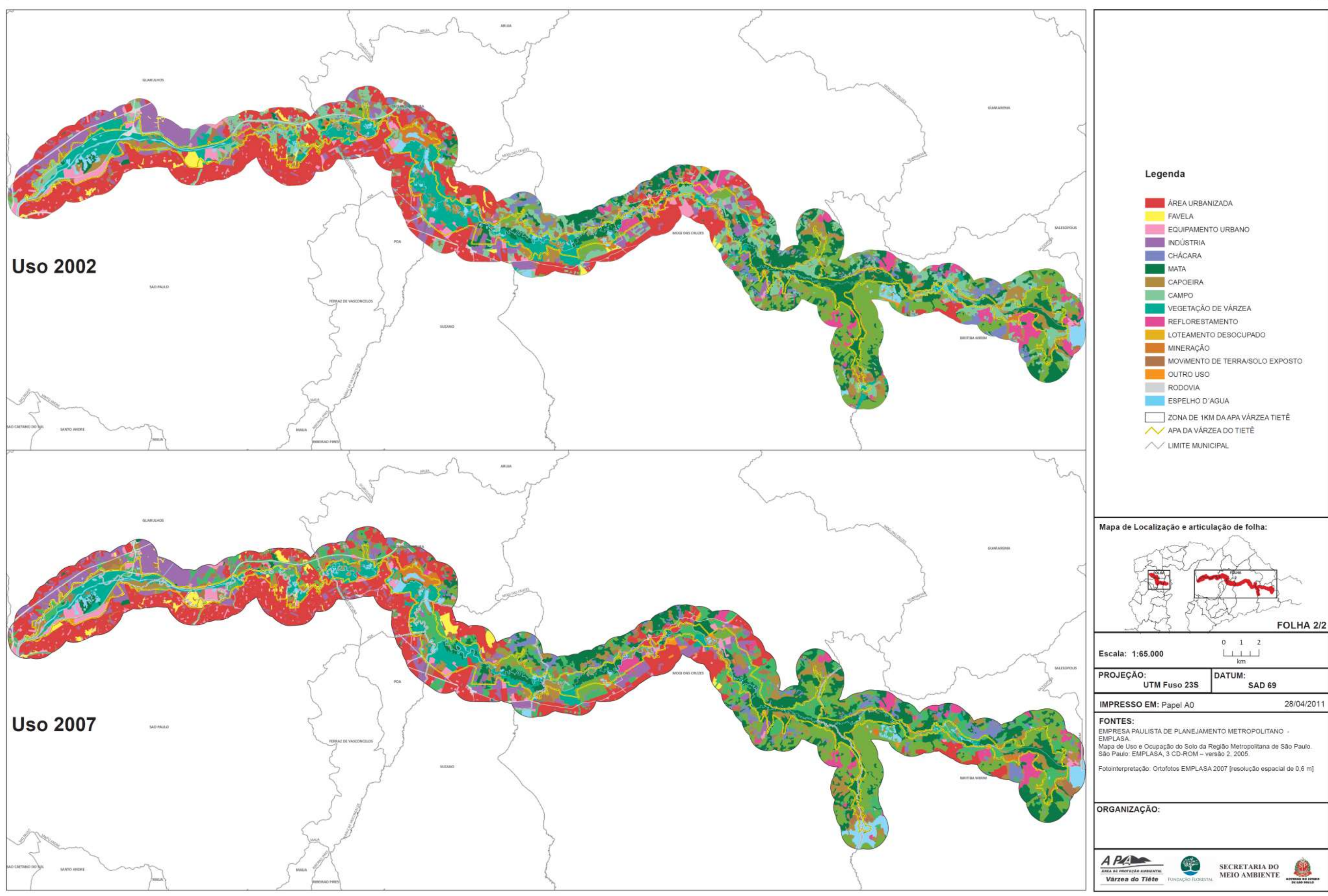

Fonte: FF (2013) 
Os diferentes tons de verde se referem às categorias de campo, mata e vegetação de várzea e ocre referente à capoeira. A parte com maior cobertura vegetal se encontra mais a leste nos municípios de Mogi das Cruzes e Biritiba Mirim. Nestes dois municípios há uma atividade agrícola importante no entorno e dentro do território da APA. Esta atividade é direcionada para a produção de hortifrutigranjeiros para o abastecimento de São Paulo, que se desenvolveu com essa finalidade a partir da década de 1950 (ZANIRATO, 2011; FF, 2013).

Ressalta-se que a região da APA possui também importância biológica, com vegetação de Mata Atlântica identificada em 2 tipos principais: florestas Ombrófilas Densas e as florestas de Várzea-Paludosas, com seus respectivos estágios sucessórios, além da vegetação aquática (não quantificada devido à escala) (FF, 2013). Destaca-se na tabela abaixo a concentração de áreas vegetadas no trecho leste:

Tabela 2 - Cobertura florestal na APA

\begin{tabular}{|l|c|}
\hline \multicolumn{2}{|c|}{ Classes de vegetação do Trecho Oeste Área (ha) } \\
\hline Floresta Ombrófila Densa Pioneira & 931,8 \\
\hline Floresta Ombrófila Densa Primária & 236,29 \\
\hline Floresta Ombrófila Densa Primária com eucalipto & 2,237 \\
\hline Floresta Ombrófila Densa Secundária Inicial & 344,82 \\
\hline Floresta Ombrófila Densa Secundária Média & 5,58 \\
\hline Floresta de Várzea-Paludosa Pioneira & 416,3 \\
\hline Floresta de Várzea-Paludosa Primária & 67,27 \\
\hline Floresta de Várzea-Paludosa Primária com eucalipto & 8,73 \\
\hline Floresta de Várzea-Paludosa Secundária Inicial & 35,67 \\
\hline Floresta de Várzea-Paludosa Secundária Média/Tardia & 1,87 \\
\hline Reflorestamento & 132,01 \\
\hline \multicolumn{1}{|c|}{ Classes de Vegetação no Trecho Leste Área (ha) } \\
\hline Floresta Ombrófila Densa Pioneira & $2.707,38$ \\
\hline Floresta Ombrófila Densa Primária & $1.995,7$ \\
\hline Floresta Ombrófila Densa Primária com eucalipto & 77,35 \\
\hline Floresta Ombrófila Densa Secundária Inicial & $3.389,8$ \\
\hline Floresta de Várzea/Paludosa Pioneira & $3.733,07$ \\
\hline Floresta de Várzea/Paludosa Primária & 930,8 \\
\hline Floresta de Várzea-Paludosa Primária com eucalipto & 115,87 \\
\hline Floresta de Várzea/Paludosa Secundária Inicial & $1.551,51$ \\
\hline Floresta de Várzea-Paludosa Secundária Média/Tardia & 227,87 \\
\hline Reflorestamento & $1.471,27$ \\
\hline & \\
\hline
\end{tabular}

Com relação à fauna, são levantados os registros existentes e a ocorrência potencial de espécies em extinção. Na ficha técnica é apresentada uma quantidade razoável de 
espécies prováveis de serem encontradas na APAVRT, considerando as áreas preservadas:

Estima-se que nos municípios abrangidos pela APAVRT foram encontradas 60 espécies de peixes ( 8 endêmicas à Bacia do Alto Tietê), 136 espécies de anfíbios (9 endêmicas à Bacia do Alto Tietê), 120 espécies de répteis (1 endêmica à Bacia do Alto Tietê), 507 espécies de aves (1 endêmica à Bacia do Alto Tietê) e 152 espécies de mamíferos, além de mais de 500 espécies de plantas. (FF, 2013, p. XXIV)

Há de destaque a ocorrência do Bicudinho do Brejo (Formicivora aff. Acutirostris), espécie em situação crítica de extinção e com uma população estimada em menos de 300 indivíduos. Apesar dessa espécie também ocorrer em São José dos Campos, a maioria está na APAVRT (FF, 2013).

Segundo Rodrigues (2015), em razão do caráter preservado da APA no Setor Leste, foi recomendado integrar as demais áreas preservadas que se encontravam no entorno ao seu território. No entanto, foi definido que essas áreas comporiam uma nova UC (RODRIGUES, 2015).

A APAVRT tem o caráter de ordenamento territorial e possui como principais instrumentos o zoneamento ambiental e o plano de manejo. No entanto, a APA ainda não possui um plano de manejo aprovado:

A própria morosidade do processo de aprovação/reprovação do PM APAVRT concorre para descaracterizar ainda mais os últimos remanescentes e enfraquecer a peça produzida, favorecendo o uso privado desses espaços. Entre esses setores, destacam-se atualmente o imobiliário, o minerário, o de disposição de resíduos, o industrial, o de serviços e da construção civil, além de usos menos privatistas como o de construção de sistema viário, implementação de equipamentos de saneamento e parques públicos, entre outros. (RODRIGUES, 2015, p. 341)

Rodrigues (2015) acrescenta que o território ser fragmentado, a despeito dos estudos técnicos e científicos, serve como argumento para diminuir o valor da UC, o que tem permitido a continuidade da degradação.

Deve-se frisar que este espaço possui outras apropriações em diferentes escalas e nos remete a um enfoque para uma relação conflituosa dos territórios sobrepostos, elemento a ser destacado considerando a abordagem territorial de Raffestin (1993) e Fernandes (2015). A presença de outros atores se apropriando de espaço e da constatação de um território ou múltiplos territórios será explorado nos capítulos subsequentes. 


\section{3- 3 - Instituições estaduais}

As instituições políticas do governo possuem um caráter importante no processo político e da ação pública, pois possuem um poder coercitivo para aplicar as políticas (DYE, 2008) e a estrutura institucional que delimitam o processo (FREY, 2000). No aspecto da estrutura institucional, é importante notar se são instituições da administração direta ou indireta, interferindo na celeridade das ações e autonomia jurídica e administrativa (MARQUES, 2003). No entanto, essas instituições estão sujeitas aos processos políticos com influência das eleições, mudanças de governantes e de partidos em razão da composição dos funcionários indicados e concursados (LIMA JUNIOR, 1998; FREY, 2000; MARQUES, 2003). Ademais, cada uma surgiu em um momento e sob a influência dos modelos administrativos distintos e estão sujeitas as diversas reformas, com destaque a última ser a gerencial (LIMA JUNIOR, 1998). No entanto, Lima Junior (1998) destaca que esse novo paradigma da administração gerencial convive e sobrepõe com os modelos anteriores.

Essas instituições apresentam interesses diversos e conflitantes, além da assimetria de poder (THOENING, 2010, MELLO-THÉRY, 2011). Para tanto, serão observadas as principais instituições políticas que possuem atribuições e competências concorrentes sobre o território da APA da Várzea do Rio Tietê.

Não se descarta a importância da participação e mobilização social, que será abordada no capítulo 5. No entanto, como já era mencionado por Côrte (1997) e mais especificamente por Costa (2012) e Silva et al. (2014), para a APAVRT, a participação social de outros grupos é assimétrica, desigual e ainda se encontra em processo de aprendizado. As instituições políticas, por outro lado, já apresentam uma maior articulação e poder de decisão sobre o território.

As instituições exploradas e analisadas serão: Secretaria do Meio Ambiente (SMA), o Conselho Estadual de Meio Ambiente (CONSEMA), a Fundação para Conservação e a Produção Florestal do Estado de São Paulo (FF), o Departamento de Águas e Energia Elétrica (DAEE), a Empresa Metropolitana de Planejamento da Grande São Paulo S/A (EMPLASA), o Desenvolvimento Rodoviário S/A (DERSA), a Companhia Paulista de Trens Metropolitanos (CPTM), a Companhia de Saneamento Básico do Estado de São Paulo (SABESP) e o Ministério Público Estadual de São Paulo (MPSP).Vale destacar que algumas destas instituições públicas possuem territórios com limites definidos mais precisamente (FF, DAEE) e outros podem se apropriar de diversos espaços no estado de 
São Paulo (DERSA, EMPLASA, SMA).Todas essas instituições de nível estadual executam projetos e políticas no território da APA, mas com diversas sobreposições, que serão explorados adiante no capítulo 4.

\section{1 - Secretaria do Meio Ambiente (SMA)}

A Secretaria do Meio Ambiente é uma instituição da administração direta e foi criada em 1986 pelo D24932/1986, que instituiu o Sistema Estadual de Meio Ambiente. A SMA se insere no Sistema Nacional do Meio Ambiente (SISNAMA), subordinada às decisões do Conselho Nacional de Meio Ambiente (CONAMA), promovendo e avaliando a Política Estadual do Meio Ambiente; coordenando o Sistema Estadual do Meio Ambiente e realizando a gestão ambiental do território paulista (SÃO PAULO, 1986).

Em 1997, com a Política Estadual de Meio Ambiente (L9509/1997), foi estabelecido o Sistema Estadual de Administração da Qualidade Ambiental, Proteção, Controle e Desenvolvimento do Meio Ambiente e Uso Adequado dos Recursos Naturais (SEAQUA). O SEAQUA é responsável pela gestão ambiental e pelas políticas ambientais do Estado de São Paulo. Sua estrutura tem como órgão central a SMA, que coordena diversos órgãos da administração direta e indireta (SÃO PAULO, 1997). A SMA foi reorganizada em 2012 com o D57933/2012, estruturando as coordenadorias, os institutos e fundações vinculados. Na figura abaixo (fig. 9) está o organograma dessa estrutura. Destaca-se a Polícia Militar Ambiental, que não faz parte do SEAQUA e coopera para atuar na fiscalização. 
Figura 9 - Organograma Sistema Ambiental Paulista

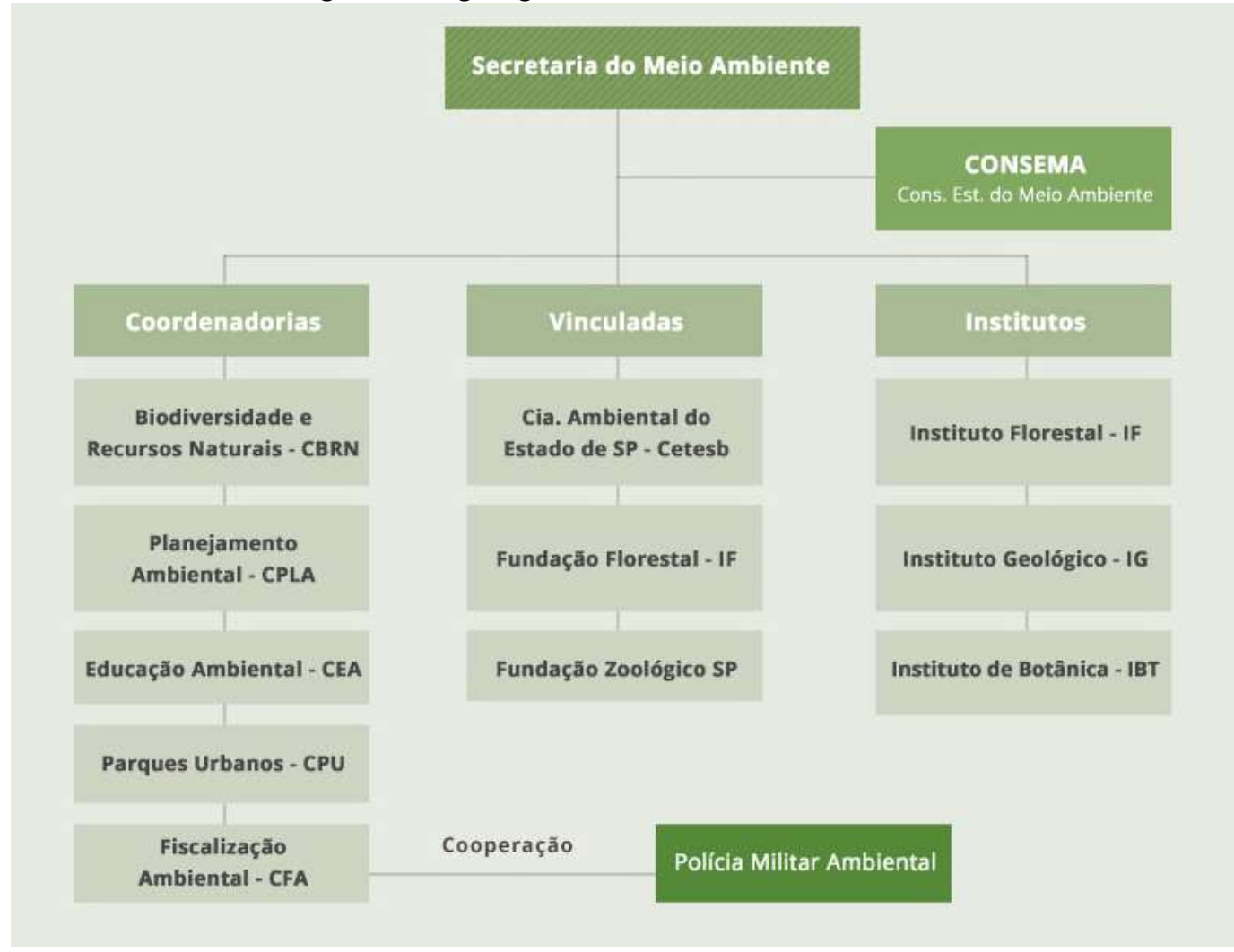

Fonte: SMA (2018a).

Para o período estudado, é importante a relação hierárquica entre as diferentes instituições do Sistema Ambiental, pois o secretário Ricardo Salles, que exerceu o cargo de 2016 a 2017, alterou várias diretorias e teve uma maior centralização da gestão das instituições que compunham o sistema. Em matéria da imprensa consta que diferentemente dos demais secretários, ele tinha a visão de que os demais órgãos não deveriam ser tão autônomos como anteriormente, o que levou a ser criticado como autoritário (ESCOBAR, 2017a).

Diversas investigações e ações foram questionadas durante a sua passagem na secretaria, como mudanças nos conselhos das UCs, acusar o Ministério Público de demagogia (ESCOBAR, 2017a), indicação de nomes com grandes $\operatorname{conflitos}^{12}$, carta de

${ }^{12}$ No caso Rafael Campolim nomeado como gerente das áreas protegidas do Alto Paranapanema, sócio ou diretor da Campo Limpo Projetos e Serviços Ltda., empresa interessada e que participou de uma reunião para concessão ou alienação de 34 áreas florestais do Instituto Florestal (ESCOBAR, 2017b). Outro nome é do secretário-adjunto Antônio Velloso Carneiro investigado por expulsar participantes da reunião sobre 
repúdio da Associação dos Pesquisadores Científicos do Estado de São Paulo, a tentativa de vender o edifício do Instituto Geológico (APQC, 2017), suspender os planos de manejo para padronizar as metodologias de elaboração dos planos $^{13}$; há ainda investigações de favorecimento no licenciamento de empresas associadas ao próprio secretário (MPSP, 2017b), inquérito de improbidade administrativa no chamamento público da venda e concessão das áreas do Instituto Florestal (GIRARDI, 2017b), além de reclamações de ser autoritário. Outro fator importante de Ricardo Salles é ser filiado ao Partido Progressista (PP) e um dos fundadores do "Endireita Brasil", grupo que tem agenda conservadora e de Estado Mínimo (AMENDOLA, 2016; LEITE, 2017). Esses dois fatores são importantes, porque assumiu a pasta da Secretaria em razão de acordo político, para angariar apoio à candidatura de João Dória à prefeitura de São Paulo (AMENDOLA, 2016), e pelas constantes contendas presenciadas e registradas na imprensa, com representantes das universidades e técnicos que seguiam ideologias avessas ao mercado, o discurso de pouca eficiência no CONSEMA e de inserir na agenda propostas de redução do papel das instituições do Sistema Ambiental Paulista (ESCOBAR, 2017a).

\section{2 - Conselho Estadual de Meio Ambiente (CONSEMA)}

No D24932/1986 ficou instituído o CONSEMA que é um órgão consultivo, normativo e recursal em que se está prevista a participação de representantes dos diferentes setores do governo estadual e da sociedade civil.

O CONSEMA tem como principais funções propor e acompanhar a política ambiental e diretrizes de defesa dos recursos naturais e ecossistemas, estabelecer normas e padrões estaduais de qualidade ambiental, apoiar e promover pesquisa voltada a conservação e preservação, assim como a educação ambiental.

Em 2009, com a lei de $\mathrm{n}^{\mathrm{o}}$ 13.507, o CONSEMA ampliou suas atribuições, passando a se manifestar sobre a Avaliação Ambiental Estratégica de políticas, planos e projetos; acompanhar e avaliar Estudos de Impacto Ambiental (EIA) e políticas públicas com considerável impacto ambiental; propor medidas de mitigação e compensatórias;

a concessão de áreas florestais e depois tentar fraudar documentos de que não teria expulso os participantes (TUFFANI, 2017).

${ }^{13}$ Informação obtida participando da reunião da Comissão Temática de Biodiversidade, Florestas, Parques e Áreas Protegidas do CONSEMA. 
incentivar o funcionamento dos Conselhos Municipais de Meio Ambiente; manifestar-se sobre a delimitação de espaços especialmente protegidos (Zoneamento Ecológico Econômico e os Planos de Manejo das Unidades de Conservação); apreciar o Relatório Anual da Qualidade Ambiental do Estado de São Paulo; e conduzir audiências públicas relativas ao licenciamento ambiental que tenham EIA.

A partir da L13507/2009, o CONSEMA passou a se organizar na presidência, na secretaria executiva, no plenário, nas comissões temáticas e nas câmaras regionais. $\mathrm{O}$ CONSEMA é presidido pelo secretário de meio ambiente e composto por 17 representantes do poder público e 18 representantes da sociedade civil, dos quais 6 são eleitos por entidades ambientalistas.

\section{3 - Fundação para Conservação e a Produção Florestal do Estado de São Paulo} (FF)

Órgão da administração pública indireta foi criado pela Lei Estadual n ${ }^{\circ}$ 5.208/1986 e com o estatuto aprovado no mesmo ano (SÃO PAULO, 1986, 2006). Originalmente vinculado à Secretaria de Agricultura e Abastecimento, com o objetivo de gerir as florestas que compunham o patrimônio do Estado (principalmente as que eram administradas pelo Instituto Florestal), ampliou seu escopo de ação em 2006, com o Sistema Estadual de Florestas (SIEFLOR) (SÃO PAULO, 1986, 2006). Atualmente é vinculada à Secretaria do Meio Ambiente do estado de São Paulo (SMA) (SÃO PAULO, 2006).

A partir do SIEFLOR, criado pelo decreto estadual $n^{0} 51453 / 2006$, a FF passou a ser um órgão executor do sistema que compreende como órgão deliberativo e consultivo o CONSEMA e a SMA como órgão central (SÃO PAULO, 2006).

A FF é responsável pela gestão da APAVRT e preside o conselho gestor da APA. O conselho gestor é composto por representantes do poder público (municipal e estadual) e representantes da sociedade civil organizada (COSTA, 2012).

Durante o período pesquisado, destaca-se o período de 2016/2017, em que a Fundação Florestal teve a sede transferida para o edifício da SMA e da CETESB, distanciando-se do Instituto Florestal (APQC, 2017). Também se destaca a mudança de diretores da Fundação Florestal: no período de 2015 a 2017 foram 6 diretores, configurando uma instabilidade nas ações da FF; no período de aprovação do Plano de Manejo da APAVRT houve a substituição do professor Paulo Almeida pelo ex-diretor da Sociedade Rural Brasileira Eduardo Soares de Camargo (TUFFANI, 2018). Outro fator 
preponderante discutido é a redução do quadro de funcionários, que tem afetado a capacidade de atuação da FF e as UCs gerenciadas ${ }^{14}$.

\section{4 - Departamento de Águas e Energia Elétrica (DAEE)}

O DAEE, criado pela lei $\mathrm{n}^{\circ} 1350 / 1951$, é uma autarquia que tem como objetivo a execução do Código das Águas (Decreto n²4643/1934) e a realização de estudos, assistência técnica, elaboração e execução de projetos de aproveitamento dos cursos de águas. Teve como base o Tenesee Valley Authority, substituindo a Inspetoria de Serviços Públicos no âmbito da energia elétrica e telefonia (SANTOS, 2014). Atualmente é o órgão responsável pela gestão do Parque Ecológico do Tietê ${ }^{15}$, pelo controle da vazão do rio Tietê, controlando a barragem da Penha, como em obras de contenção de enchentes, outorga para o uso da água e intervenções nos rios; além de ser responsável pelo Programa Várzeas do Tietê (PVT) (SÃO PAULO, 1976; DAEE, 2010, 2016).

O DAEE detinha ações e controle de diversas companhias públicas, como a SABESP, a Companhia Energética de São Paulo, a Eletricidade de São Paulo S.A., da Companhia de Tecnologia de Saneamento Ambiental e a Companhia Paulista de Força e Luz. Entretanto, em 1990, com a L6851/1990, o controle e as ações que o DAEE detinha passaram para a Secretaria da Fazenda do Estado.

Sua atuação é relacionada às obras de engenharia para a contenção de enchentes, como barragens, polderes e piscinões (DAEE, 2016). Para esta pesquisa, as principais ações a serem analisadas estão relacionadas a essas infraestruturas de contenção e regulação do regime do rio, assim como novos projetos, como o Parque Linear associado ao PVT.

\section{5 - Comitê de Bacia Hidrográfica do Alto Tietê (CBHAT)}

O Comitê de Bacia Hidrográfica é um espaço participativo de gestão dos recursos hídricos regional. Os comitês paulistas surgiram com a Política Estadual de Recursos Hídricos (L7663/91) e integram o Sistema de Integrado de Gerenciamento de Recursos Hídricos de São Paulo (SÃO PAULO, 1994; RIBEIRO, 2004).

\footnotetext{
14 Informação oral coletada durante o II Seminário A Dimensão Social da Formação Profissional e do I Fórum Integrado da Zona de Amortecimento do Parque Estadual da Cantareira.

${ }^{15}$ Ver mapa do Zoneamento Vigente da APA no tópico 2.1.
} 
Segundo a L7663/91, os comitês podem ser consultivos ou deliberativos e possuem a participação paritária entre os municípios e os representantes do estado, além da participação da sociedade civil, que não deve ultrapassar um terço dos votos. Na lei são especificados os representantes do governo estadual e da sociedade civil. Como representação do governo estadual, são inseridos órgãos da administração direta e indireta que estejam relacionados com a gestão de recursos hídricos, a proteção ambiental, o planejamento estratégico e a gestão financeira. Para a sociedade civil, a participação se estende às universidades, institutos de pesquisa, entidades associativas que representam usuários e associações (profissionais, comunitárias, ONGs) especializadas em recursos hídricos (SÃO PAULO, 1991).

Ao comitê, compete: aprovar o Plano de Bacia Hidrográfica; o plano plurianual; aprovar a utilização de recursos voltados para utilização, conservação, proteção e recuperação; aprovar o relatório da situação dos recursos hídricos; mediar os conflitos pelo uso da água; promover estudos e acompanhar obras e projetos (SÃO PAULO, 1991).

O CBHAT é um dos 21 comitês do Estado de São Paulo e divide-se em 5 subcomitês: Alto Tietê-Cabeceiras, Cotia-Guarapiranga, Juqueri-Cantareira, BillingsTamanduateí, Pinheiros-Pirapora (SIGRH, 2018). Destaca-se que os limites da Bacia Hidrográfica do Alto Tietê são muito próximo dos limites da Região Metropolitana de São Paulo.

\section{6 - Empresa Metropolitana de Planejamento da Grande São Paulo S/A (EMPLASA)}

A EMPLASA foi criada pela lei complementar $n^{\circ} 94 / 1974$ em conjunto com a criação da Região Metropolitana de São Paulo e tem com o objetivo integrar o planejamento e as políticas públicas a nível metropolitano e regional. A EMPLASA é uma sociedade de economia mista subordinada à Casa Civil.

Atualmente, com a discussão da governança metropolitana e o Estatuto da Metrópole L13089/2015, passou a ter a atribuição da elaboração do Plano de Desenvolvimento Urbano Integrado (PDUI). Para o processo de elaboração, foram convidados representantes das 39 municipalidades, assim como realizaram-se audiências públicas para discussão e formulação do PDUI.

O PDUI, como instrumento legal, possui um caráter mais coercitivo que a APAVRT além de possuir uma capacidade de ordenar o território e ser uma possibilidade de articulação para a APA no que se refere a ampliar sua área de proteção. 
Durante as reuniões temáticas dos Grupos de Trabalho de Macrozoneamento, foi observado que os critérios principais são de uma integração econômica e logística da metrópole, pautada em critérios de uma geografia quantitativa. Vale ressaltar as propostas para a temática ambiental e formas de fortalecer o que está definido para as UCs.

O desenvolvimento deste plano se iniciou em 2016 e seguirá por 2018. Seu processo e relação com as outras políticas será abordado com mais profundidade adiante.

\section{7 - Desenvolvimento Rodoviário S/A (DERSA)}

A DERSA, criada pelo decreto lei n. 5/1969, é uma sociedade mista constituída com a participação do Departamento de Estradas de Rodagem (DER). A DERSA, assim como o DER, são subordinados à Secretaria de Logística e Transportes. Criada com a finalidade de atender ampliação e melhoramento da Via Anchieta e da construção da Rodovia dos Imigrantes, sua atuação se ampliou com outras obras viárias e administração de estradas do estado. Destaca-se, atualmente, entre as obras relacionadas à DERSA, o Rodoanel, o qual o trecho leste intersecta a região da APA.

\section{8 - Companhia Paulista de Trens Metropolitanos (CPTM)}

A CPTM é uma sociedade de economia mista subordinada à Secretaria dos Transportes Metropolitanos. Foi criada pela lei $n^{0} 7.861 / 1992$ e sua atribuição está relacionada ao transporte metropolitano de passageiros, operação de estações intermodais e ampliação da oferta de transporte sobre trilhos.

As linhas de trem operadas pela CPTM são originárias das antigas linhas que operavam na região metropolitana de São Paulo (ISODA, 2013). Essas linhas, que foram incorporadas e passaram a ser administradas pela CPTM, estão representadas no esquema abaixo (fig. 10), feito por Isoda (2013). 
Figura 10 - Esquema da evolução das linhas incorporadas pela CPTM.

Linha do tempo das companhias ferroviárias paulistanas

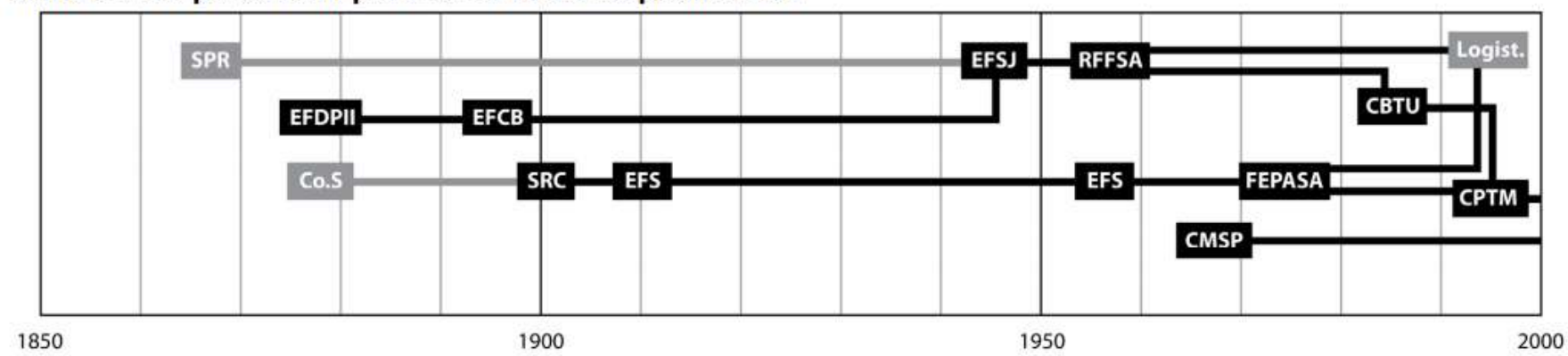

Estão representadas apenas as companhias cujas linhas se converteram em trens metropolitanos. Em cinza as companhias privadas, e em preto as companhias estatais. Siglas: SPR - São Paulo Railway; EFDPII - Estrada de Ferro Dom Pedro II; Co. S - Companhia Sorocabana; EFCB - Estrada de ferro Central do Brasil; SRC - Sorocabana Railway Company; EFS - Estrada de Ferro Sorocabana; EFSJ - Estrada de Ferro Santos a Jundiaí; RFFSA - Rede Ferroviária Federal S.A.; FEPASA - Ferrovias Paulistas S.A.; CMSP - Companhia do Metropolitano de São Paulo; CBTU - Companhia Brasileira de Trens Urbanos; CPTM - Companhia Paulista de Trens Metropolitanos. "Logist." Representa diversas empresas privadas de transporte de cargas (ALL, MRS, CVRD, entre outras).

Fonte: Isoda (2013)

Institucionalmente, Stefani (2013) verificou importantes aspectos, como: a perda da importância do transporte ferroviário frente ao rodoviário; a integração com o transporte metroviário e planos de privatização e concessões. No âmbito das privatizações e concessões, há também planos de desativação de alguns trechos considerados pouco rentáveis ou voltados exclusivamente para transporte de cargas (STEFANI, 2007).

Outro fator importante é o secretário dos transportes metropolitanos, que ocupou o cargo de 1995 a 2001, Claudio de Senna Frederico. Ele criticava as condições precárias das linhas ferroviárias e dos equipamentos, que terminariam de ser integradas à CPTM em 1995 (FREDERICO, 2001). Inclusive, existiam planos de desativar a linha 12 (antiga Variante), que não ocorreu em razão da criação da USP Leste (STEFANI, 2007).

Para esta pesquisa, o foco será a obra da linha 13, a qual intersecta a APAVRT. O processo será analisado com maior detalhe no capítulo 4.

\section{9 - Companhia de Saneamento Básico do Estado de São Paulo (SABESP)}

A SABESP é uma sociedade por ações e foi criada em 1973, a partir da fusão da Companhia Metropolitana de Água de São Paulo e da Companhia Metropolitana de Saneamento de São Paulo, além da incorporação da Superintendência de Águas e Esgoto da Capital e de parte do Fomento Estadual de Saneamento Básico através da L119/1973. A SABESP foi criada com o objetivo de planejar, executar e operar o saneamento básico no estado de São Paulo, respeitando a autonomia municipal para aderir ou não aos serviços da SABESP (SÃO PAULO, 1973). Na época de sua constituição, o DAEE mantinha a maioria absoluta das ações. A partir da L6851/1990, o controle majoritário 
passou para a Secretaria da Fazenda e, pela L8523/1993, reservou-se 2/3 das ações para o governo. As demais ações, desde a primeira lei, podem ser adquiridas por pessoas físicas e jurídicas (SÃO PAULO, 1973). Mais recentemente, em 2017, com a L16525, foi reorganizada a sociedade da SABESP e criada a Sociedade Controladora. Atualmente o controle do Capital Social é de 50,3\% do Governo do Estado, 31,6\% se encontra na Bolsa de Valores, Mercadorias e Futuros de São Paulo (BM\&FBOVESPA) BM\&FBOVESPA e na New York Stock Exchange (NYSE) (LEITE, 2015a).

A abertura de capitais foi feita em 2002 na BM\&FBOVESPA e na NYSE, o que implicou que a SABESP passou a adotar medidas para se adequar às regras da governança corporativa (SABESP, 2018a). Foi exigido à SABESP:

(a) manter um comitê ou conselho de auditoria, conforme dispensa aplicável disponível a emissores privados, que atenda a determinadas exigências, conforme explicado abaixo, (b) disponibilizar prontamente um certificado emitido por seu diretor-presidente comprovando a inexistência de qualquer descumprimento relevante das regras de governança corporativa, e (c) fornecer uma breve descrição das diferenças significativas entre as práticas de governança corporativa da companhia e as da NYSE que devem ser seguidas por companhias listadas americanas. (SABESP, 2018)

Essa abertura foi tema de discussões e críticas no período da crise de abastecimento hídrico, pois $29,7 \%$ dos lucros eram voltados para os acionistas e questiona-se a capacidade de investimento e o direcionamento dos investimentos (LEITE, 2015a).

A partir das L12292/2006 e da LC1025/2007 a SABESP pode criar subsidiárias, participar de empresas públicas ou sociedades mistas, do bloco de controle ou ações de outras empresas e constituir consórcios com empresas (nacionais e estrangeiras) ou companhias de saneamento (municipais ou estaduais).

\subsection{0 - Departamento Hidroviário (DH)}

O Departamento Hidroviário (DH) surgiu em 1966, com a L9318/1966 como órgão da então Secretaria dos Negócios dos Transportes. Atualmente as atribuições do Departamento Hidroviário são relativas à administração da Hidrovia Tietê-Paraná e a gestão e monitoramento do uso das hidrovias (SÃO PAULO, 2000).

Para esta pesquisa, são relevantes as atribuições do DH, que definiu como um dos objetivos o estudo de pré-viabilidade técnica do Hidroanel Metropolitano (FPH, 2010). Esse estudo foi realizado pela Faculdade de Arquitetura e é um dos objetos de análise dessa pesquisa. 
Um aspecto importante a ser considerado na atuação institucional é o PL199/2018, proposto pelo governador, que estabelece a transferência das competências, de pessoal e do patrimônio do DH para o Departamento de Estradas de Rodagem (DER), junto com a extinção do Departamento Aeroviário do Estado de São Paulo (DAESP). A justificativa para este projeto de lei é a ociosidade dos funcionários do DER e do DAESP, em razão das privatizações e concessões, e, por outro lado, da demanda de pessoal do DH em razão da intensificação das atividades da hidrovia Tietê-Paraná.

\subsection{1 - Ministério Público do Estado de São Paulo (MPSP)}

Uma importante instituição a ser considerada nessa pesquisa é o Ministério Público de São Paulo (MPSP), que tem um papel importante para a legitimação ou impedimento dos planos e projetos analisados.

A origem do Ministério Público do Estado de São Paulo ocorreu na primeira república, com a lei 18 de 21 de novembro de 1891, apesar de existir desde o período colonial a figura do promotor de justiça, nas Ordenações Manuelinas de 1521 e nas Ordenações Filipinas de 1603, e a primeira menção a ministério público ser do período do império (OLIVEIRA, 2013).

A partir da década de 1930 o Ministério Público se estruturou e passou a se concentrar em suas atribuições (OLIVEIRA, 2013). A função do MPSP, de acordo com a Constituição Estadual de 1989 e a Lei Orgânica do Ministério Público (LC734/1993).

Art. 1. O Ministério Público é instituição permanente, essencial à função jurisdicional do Estado, incumbindo-lhe a defesa da ordem pública, do regime democrático e dos interesses sociais e individuais indisponíveis.

Os órgãos executores do MPSP são: o Procurador-Geral de Justiça; o Colégio de Procuradores de Justiça; o Conselho Superior do Ministério Público; os Procuradores de Justiça e os Promotores de Justiça (SÃO PAULO. 1993). O MPSP, por via desses órgãos, deve atuar sobre os seguintes temas, segundo a L8625/1993:

Art. 25. Além das funções previstas nas Constituições Federal e Estadual, na Lei Orgânica e em outras leis, incumbe, ainda, ao Ministério Público:

(...)

IV - promover o inquérito civil e a ação civil pública, na forma da lei:

a) para a proteção, prevenção e reparação dos danos causados ao meio ambiente, ao consumidor, aos bens e direitos de valor artístico, estético, 
histórico, turístico e paisagístico, e a outros interesses difusos, coletivos e individuais indisponíveis e homogêneos;

b) para a anulação ou declaração de nulidade de atos lesivos ao patrimônio público ou à moralidade administrativa do Estado ou de Município, de suas administrações indiretas ou fundacionais ou de entidades privadas de que participem;

V - manifestar-se nos processos em que sua presença seja obrigatória por lei e, ainda, sempre que cabível a intervenção, para assegurar o exercício de suas funções institucionais, não importando a fase ou grau de jurisdição em que se encontrem os processos;

(..)

VII - deliberar sobre a participação em organismos estatais de defesa do meio ambiente, neste compreendido o do trabalho, do consumidor, de política penal e penitenciária e outros afetos à sua área de atuação;

(...)

Destacam-se entre essas funções àquelas relativas à garantia dos direitos difusos e ao meio ambiente. Em função dessas atribuições, o MPSP tem um papel fundamental nos processos estudados e é uma instituição recorrente em alguns processos da pesquisa. 


\section{4- Conflitos, multiescalaridade da ação pública}

A APAVRT se insere em uma área com diversas outras instituições, políticas, planejamentos e projetos concomitantes. Neste sentido, há diversos conflitos de ordem ambiental e territorial, em razão dos objetivos de cada uma destas instituições e do recorte territorial, de planejamento e da diversidade de projetos elaborados e aprovados.

Esses conflitos podem ser analisados a partir dos múltiplos usos potenciais do território (TORRE ET AL, 2006; FERNANDES, 2015), da interação entre as diferentes instituições governamentais (THOENING, 2010; MELLO-THÉRY, 2011), a partir da apropriação de cada instituição (RAFFESTIN, 1993, 2012, 2015) e, com apoio da policy analysis (FREY, 2000), podem explicitar a sobreposição e os embates de poder no território.

Primeiramente, serão elencadas as políticas públicas a partir de seus desdobramentos em planos, programas e projetos, e a dimensão cronológica da elaboração e execução destas políticas públicas e projetos nas figuras 11 . 
Figura 11 - Esquema cronológico das políticas públicas que se sobrepõem com as respectivas instituições e leis.

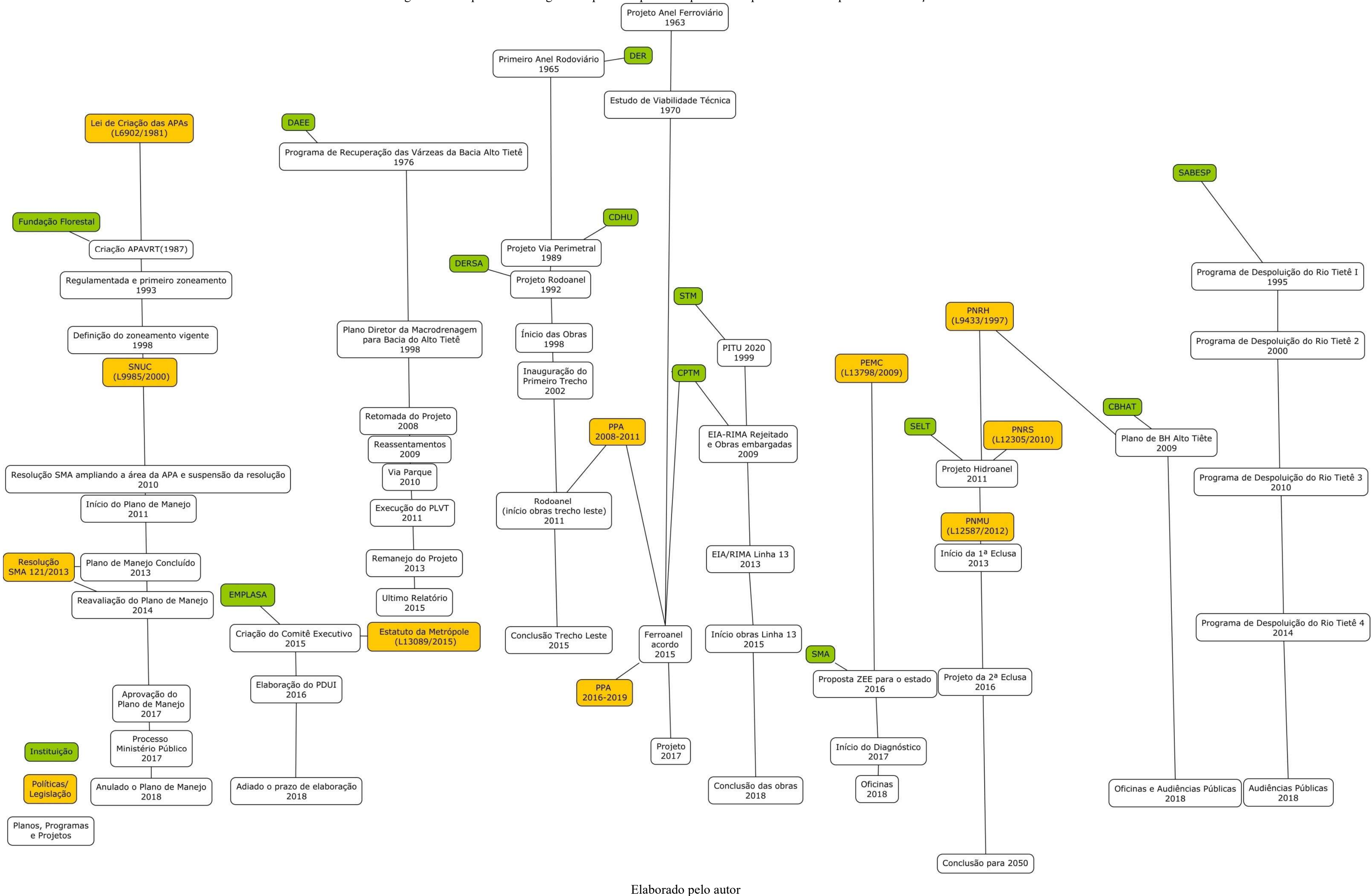


No esquema acima estão colocados cronologicamente os principais planos, programas e projetos que têm a área da APAVRT como local de ação ou se sobrepõem à APA. Destacase que diversos projetos são posteriores à criação da APAVRT e se iniciam durante a elaboração do Plano de Manejo, com exceção do Programa Várzeas do Rio Tietê (PVT). No período do diagnóstico do Plano de Manejo, os projetos do PVT e o Rodoanel foram elencados como conflitantes pela falta de articulação institucional (FF, 2013a).

Outro aspecto a ser destacado do diagrama, são os processos e as alterações dos projetos ao longo do tempo, já que alguns projetos apresentam maiores alterações e maior tempo para sua execução. Nos próximos tópicos serão descritos e comentados esses planos e projetos, que se sobrepõem territorialmente e cronologicamente no território da APA. A ordem dos planos e projetos será abordada de acordo com a escala e elencados na tabela abaixo.

Quadro 3 - Quadro com as escalas e municípios abrangidos pelos planos e projetos analisados

\begin{tabular}{|c|c|c|}
\hline Planos e Projetos & Escala & $\begin{array}{c}\text { Municípios } \\
\text { Abrangidos }\end{array}$ \\
\hline $\begin{array}{c}\text { Zoneamento Ecológico- } \\
\text { Econômico }\end{array}$ & Estadual & 645 \\
\hline $\begin{array}{c}\text { Plano de Desenvolvimento } \\
\text { Urbano Integrado }\end{array}$ & Metropolitana & 39 \\
\hline Plano de Bacia Hidrográfica \\
do Alto Tietê & Bacia Hidrográfica & 36 \\
\hline Projeto de Despoluição do \\
Tietê & Metropolitana & 11 \\
\hline APA Várzea do Rio Tietê & Metropolitana & 12 \\
\hline Programa Várzeas do Tietê & Metropolitana & 8 \\
\hline Rodoanel & Metropolitana & 16 \\
\hline Ferroanel Norte & Metropolitana & 4 \\
\hline Hidroanel & Metropolitana & 15 \\
\hline Linha 13 & Metropolitana & 2 \\
\hline
\end{tabular}

Elaborado pelo autor

A tabela acima hierarquizou os planos e projetos de acordo com a área de influência de cada um. Destaca-se que a maioria se enquadra na escala metropolitana. Contudo, é 
importante pontuar que, enquanto o Plano de Desenvolvimento Urbano Integrado se refere a um plano de ordenamento territorial para toda a metrópole, a linha 13, por outro lado, se refere somente a 2 municípios de atuação. Outro elemento a se destacar é que a escala do Plano de Bacia Hidrográfica do Alto Tietê é muito próxima da escala metropolitana, pois os limites da Bacia do Alto Tietê são muito próximos aos limites da Região Metropolitana de São Paulo.

\section{1 - Zoneamento Ecológico-Econômico}

Deverá ainda se sobrepor à APA o Zoneamento Ecológico-Econômico ${ }^{16}$ (ZEE) do Estado de São Paulo, decorrente da Política Estadual de Mudanças Climáticas (L13798/2009). O ZEE é um instrumento de ordenamento territorial baseado nos princípios de um zoneamento ambiental compatibilizar as atividades econômicas e a conservação/preservação. O ZEE tem como base diversas discussões, como a proposta por Ab'Saber (1989) do molde e contramolde; Becker e Egler (1997) analisando as potencialidades e fragilidades do território baseado nos princípios da ecodinâmica e nas condições das áreas serem consolidadas, de expansão, de recuperação ou de conservação; e Crepani et al. (2001), com um diagnóstico baseado no geoprocessamento e combinando diversas cartas temáticas e prognósticos.

O ZEE, portanto, tem como objetivo orientar o desenvolvimento, respeitando a capacidade suporte do território. Por esse caráter de direcionar ou restringir as atividades econômicas, a ocupação e a preservação, o ZEE tem um importante impacto para a APA, que poderia potencializar sua conservação ou impactá-la, direcionando uma maior concentração de atividades no seu entorno ou sobre seu território.

Em 2011 foi realizado o Seminário “Zoneamento Ecológico-Econômico (ZEE) - Base para o Desenvolvimento Sustentável do Estado de São Paulo" para familiarizar e começar a preparação dos técnicos da SMA na condução do ZEE no estado a partir das experiências de

${ }^{16}$ O ZEE é um instrumento de organização do território segundo critérios ambientais e socioeconômicos para um desenvolvimento sustentável. O ZEE orienta as políticas, os planos e programas que utilizem diretamente ou indiretamente os recursos naturais assim como as atividades públicas e privadas (BRASIL, 2002). 
outros estados e discussões metodológicas. Em 2016 foi instituído pela resolução SMA 14/2016 o Grupo de Trabalho responsável pelo ZEE, constituído por representantes da Assessoria Técnica do Gabinete da SMA, pela Coordenadoria de Planejamento Ambiental (CPLA), Coordenadoria de Biodiversidade e Recursos Naturais, Coordenadoria de Fiscalização Ambiental, Coordenadoria de Educação Ambiental, Coordenadoria de Parques Urbanos, Instituto Geológico, Instituto de Botânica, Instituto Florestal, pela CETESB, a Fundação Florestal e a Fundação Parque Zoológico de São Paulo.

O ZEE está definido para ser elaborado por bacia hidrográfica (SMA, 2016) e as atividades se iniciaram em 2017, com algumas oficinas em 2018 e a previsão de conclusão em 2019. O ZEE está sendo realizado pela SMA, em parceria com a empresa de consultoria GeoBrasilis, com a Fundação Sistema Estadual de Análise de Dados (SEADE) e o Prof. Claudio Egler (SMA, 2018b). Destaca-se como uma das metodologias o uso da análise espacial e a identificação de serviços ecossistêmicos para identificar nas áreas as fragilidades e potencialidades ${ }^{17}$.

\section{2 - Plano de Desenvolvimento Urbano Integrado (PDUI)}

O Plano de Desenvolvimento Urbano Integrado (PDUI) é uma exigência do Estatuto da Metrópole (L13089/2015), que direcionará os planos diretores dos municípios envolvidos. Diferente do Plano de Manejo da APAVRT (PMVRT), o PDUI tem um caráter de subordinação maior, em que apresenta uma sanção de improbidade administrativa para o município que não se adequar ao PDUI. Este plano está sendo conduzido pela EMPLASA, que convidou os municípios para participarem do processo de elaboração do mesmo. Para o território da APA, destaca-se que o PDUI, até o momento, nas discussões dos Grupos de Trabalho (GT) de Macrozoneamento, definiu que as áreas das APAs deveriam seguir o regramento definido pelos seus respectivos Planos de Manejo. Para diversas APAs da RMSP, há o problema da ausência de Planos de Manejos, inclusive a APAVRT.

\footnotetext{
${ }^{17}$ Informação obtida na palestra sobre o ZEE no Estado de São Paulo no ciclo de seminários do Instituto de Economia Agrícola
} 
No PDUI existem instrumentos interessantes que podem colaborar para uma gestão territorial em nível metropolitano e pode fortalecer a própria APAVRT. Entre os instrumentos de destaque, há os pagamentos por serviços ambientais, que podem incentivar a preservação. A discussão de desenvolvimento e crescimento urbano nas oficinas do GT de Macrozoneamento também apresenta a tensão, que era presente na discussão do PM da APA VRT, de não imobilizar economicamente os municípios para poderem crescer via expansão urbana, indústria ou atividades agrícolas ou silvícolas.

O processo de elaboração foi restrito à equipe técnica e ao conselho até a apresentação do plano setembro/outubro de 2017 e foram realizadas as audiências públicas, consultando o conteúdo prévio. A etapa seguinte consiste no encaminhamento para a assembleia legislativa e para consulta pública da minuta do projeto, para, então, ser aprovado.

O plano apresentado tem como objetivos conter a expansão urbana e promover uma metrópole compacta e o desenvolvimento sustentável na agropecuária (EMPLASA, 2017). O plano se subdivide em três escalas de atuação no ordenamento territorial: as Macrozonas, as quais estabelecem as diretrizes para os planos diretores; as Estratégias para Ação Metropolitana, que objetivam integrar redes ou sistemas regionais e as Áreas Estratégicas (EMPLASA, 2017). Além desses elementos, está prevista a criação de um fundo metropolitano, uma agência e o sistema de informações metropolitano. 


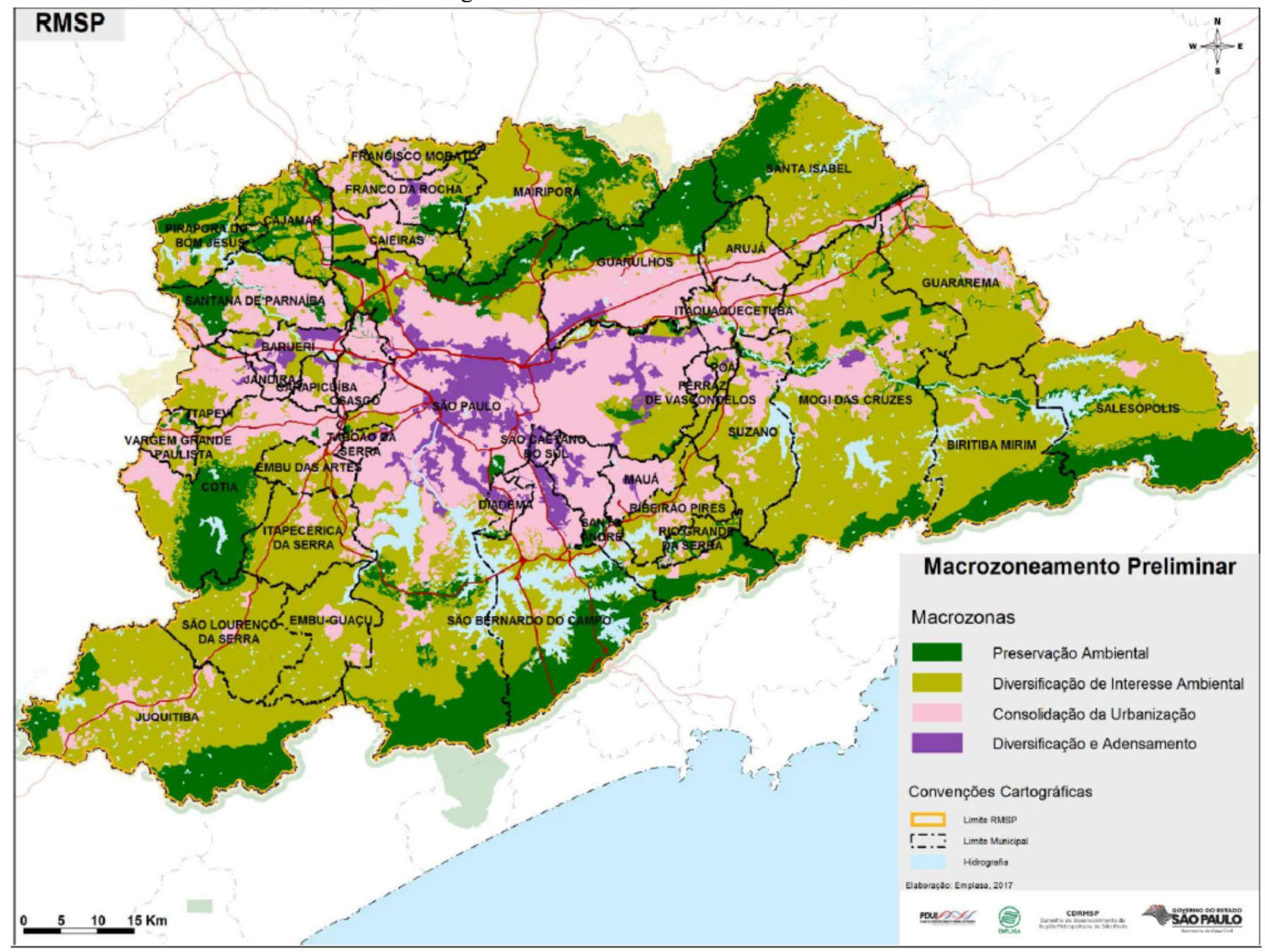

Fonte: EMPLASA (2017)

As propostas estruturadas no PDUI que se destacam para a área são: da ampliação do sistema de saneamento, o programa de combate de enchentes (piscinões, desassoreamento, recuperação de várzeas e projetos para aumentar a permeabilidade do solo), pagamento por serviços ambientais (voltado para RPPNs, unidades de preservação integral que prejudiquem o desenvolvimento do município e que contribuam para a produção de água para abastecimento público) e propostas de apoio ao Hidroanel e ao Ferroanel (EMPLASA, 2017).

Basicamente, as ações estruturadas com relação às questões hídricas são voltadas para estratégias de saneamento e abastecimento, a fim de evitar problemas relacionados à Crise de Abastecimento, obras de infraestrutura de combate às enchentes e grandes obras de transporte como o Hidroanel e o Ferroanel. 
Originalmente, o prazo final para se concluir o PDUI era o fim de 2017, no entanto, foi editada a Medida Provisória 818/2018, que prolonga o prazo para 2021.

\section{3 - Plano de Bacia Hidrográfica do Alto Tietê (PBHAT)}

O Plano de Bacia Hidrográfica é um instrumento de planejamento e gestão da Política Estadual de Recursos Hídricos (L7663/1991) e da Política Nacional de Recursos Hídricos (L9433/1997). O Plano de Bacia Hidrográfica tem como foco a gestão e a qualidade dos recursos hídricos da bacia hidrográfica e é elaborado com base em um diagnóstico com a proposição de um plano de ações. O Plano é submetido à apreciação do Comitê de Bacia Hidrográfica, que deve aprovar o plano e, posteriormente, ocorre a audiência pública com relação ao seu conteúdo.

Atualmente, está em debate o novo Plano de Bacia Hidrográfica do Alto Tietê, que tem como horizonte de escopo de planejamento os anos de 2015 a 2045. Durante as oficinas elaboradas entre os meses de fevereiro e abril de 2018, foram apresentados os resultados preliminares para serem avaliados pelos representantes do poder público e da sociedade civil. O plano também procurou resgatar os estudos das Áreas de Proteção de Mananciais e o Plano de Macrodrenagem. Destaca-se, em particular, no dia da apresentação do Plano de Macrodrenagem, que, para solucionar os problemas de inundação na bacia hidrográfica, será necessário ampliar a área dos reservatórios de contenção (populares piscinões) de $10 \mathrm{mil} \mathrm{km}{ }^{2}$

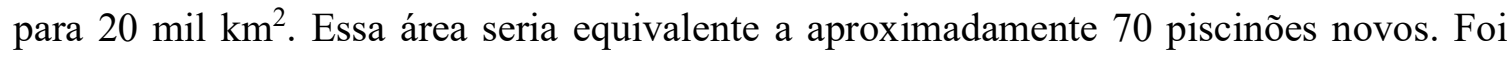
questionada a importância das planícies de inundação e sua recuperação como alternativa. A resposta do pesquisador no debate foi que isso era impossível, dada a inexistência de várzeas nos principais rios Tietê, Pinheiros e Tamanduateí, informação que conflita com os estudos conduzidos pela equipe da professora Cleide Rodrigues (principalmente com relação ao rio Tietê). Posteriormente verificada a versão preliminar do plano, reconhecia-se a existência das planícies de inundação, no entanto sem nenhuma ação diretamente voltada para a área.

A situação acima descrita suscita debates sobre a questão da formulação de alternativas no ciclo de políticas públicas e também questões epistemológicas e disciplinares, que respaldam certas alternativas e soluções técnicas.

O PBHAT aborda a questão do Hidroanel e de seus impactos na dinâmica hídrica do rio Tietê. Na oficina participativa, foi questionada a relação do plano com o Hidroanel e 
a resposta apresentada continha muitas ressalvas, pois, segundo o pesquisador, existiam questões importantes com relação às eclusas, que não tiveram seus impactos devidamente dimensionados, além de descrições de como seria feita a adequação das estruturas existentes nos rios Tietê e Pinheiros.

\section{4 - Programa de Despoluição do Rio Tietê}

O Programa de Despoluição do Rio Tietê entrou na agenda política a partir da demanda da sociedade civil na década de 1990. Foi realizado um abaixo assinado, promovido pela SOS Mata Atlântica e a Rádio Eldorado, exigindo-se a despoluição do rio Tietê. A partir da cobrança da sociedade, a SABESP começou o programa de despoluição do rio (MORI, 2017; SABESP, 2018b). A despoluição também se inseriu nos discursos políticos, com promessas de despoluição em 1993, do então governador Antônio Fleury Filho, do secretário de Recursos Hídricos em 2004 e do então governador Geraldo Alckmin, em 2012 e 2014 (MORI, 2017).

Dada a dimensão e a extensão da poluição do rio Tietê, o projeto foi dividido em várias etapas, com o objetivo de universalizar o saneamento básico na RMSP (SABESP, 2018b). Na figura 13, está representada a ampliação da rede coletora de esgoto, desde a etapa 1 até as áreas propostas para o restante da $4^{\mathrm{a}}$ etapa em 2018.

O programa tem sido financiado pelo BID desde a primeira etapa e as ações do programa se caracterizam pela ampliação da cobertura da coleta de esgoto, ampliação e construção de estações de tratamento e melhoria na gestão da SABESP (SABESP, 2018b). . 
Figura 13 - Esquema da expansão da rede coletora de esgoto na RMSP

Expansão do Sistema Principal de Esgotos da RMSP

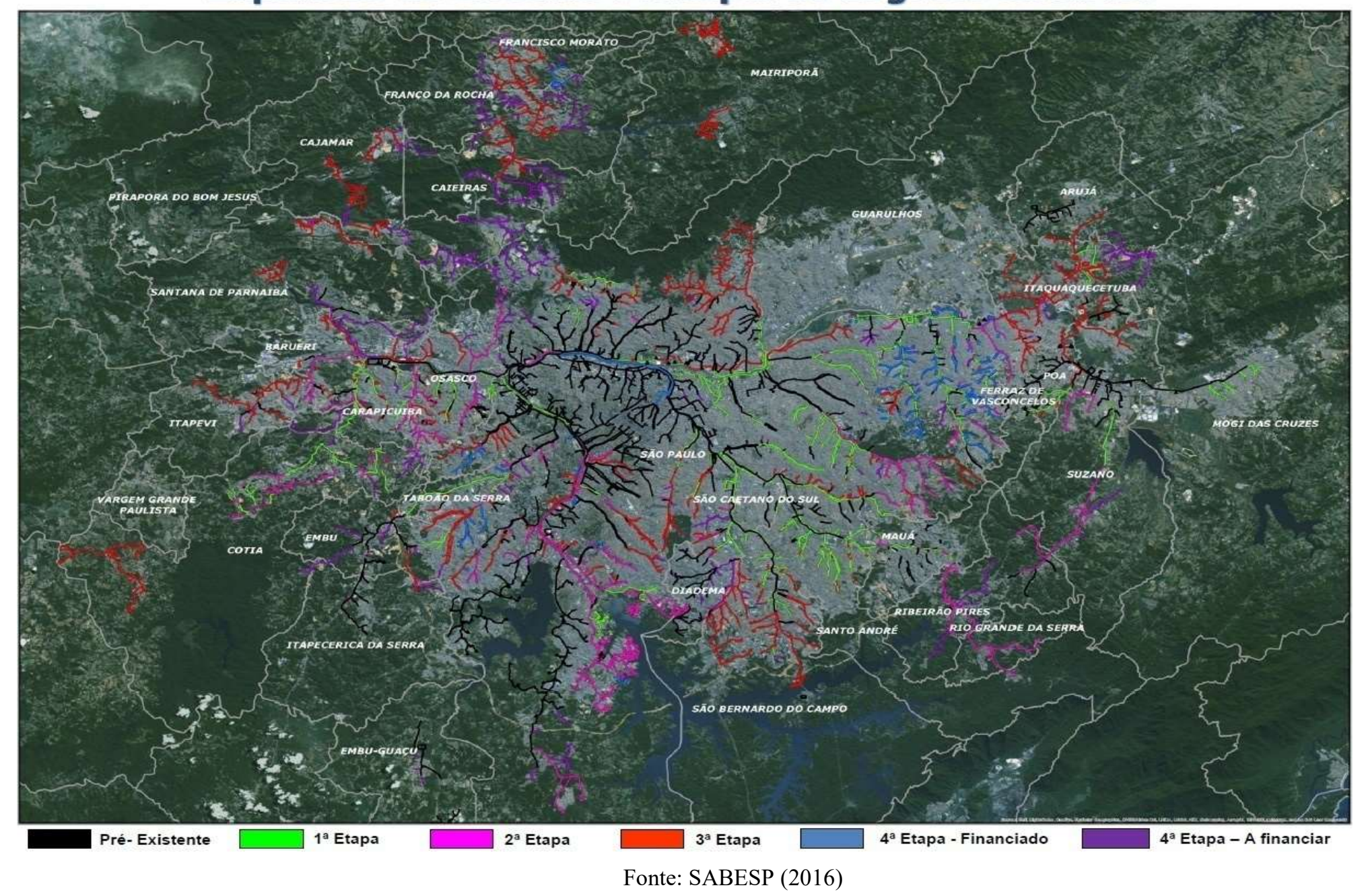




\section{5 - Plano de Manejo da APA da Várzea do Rio Tietê}

O plano de manejo foi iniciado em 2011, após a assinatura do termo de referência entre a Fundação Florestal e unidades da USP (a Escola de Artes, Ciências e Humanidades e a Faculdade de Filosofia, Letras e Ciências Humanas). A elaboração do plano teve 3 coordenadores, sendo a primeira e que estabeleceu a cooperação com a Fundação Florestal a Profa. Dra. Neli Aparecida de Mello-Théry, seguida da Profa. Dra. Cleide Rodrigues e, por último, o Prof. Dr. Jurandyr Ross. Para o diagnóstico, foram realizadas oficinas participativas, nas quais eram apresentados os resultados, em conjunto com mapas, para que representantes da sociedade civil colaborassem e criticassem (SILVA ET AL., 2014).

O processo de elaboração do diagnóstico foi um momento de aprendizado dos participantes, que inicialmente tinham diversas demandas, algumas das quais não competiam ao Plano de Manejo e ao Conselho, e aos poucos foram incorporando parte dos argumentos conservacionistas (SILVA ET AL., 2014).

Por fim, depois de um extenso estudo, definiu-se um plano de ações e um novo zoneamento para a APAVRT, pautado pelos processos físicos e pela dinâmica do rio Tietê. Foram estabelecidas 3 zonas: Zona de Conservação Hidrodinâmica do Cinturão Meândrico (ZCHCM), Zona de Conservação Hidrodinâmica da Planície Fluvial (ZCHPF) e a Zona de Requalificação Ambiental e da Paisagem (ZRAP) (FF, 2013). Também foram definidas 3 áreas prioritárias: para a Recuperação Ambiental, para a Recuperação Ambiental das Atividades Minerárias e para a Requalificação Ambiental e da Paisagem (FF, 2013).

Os critérios para definição dessas 3 zonas foram baseados na fragilidade ambiental, grau de ocupação, remanescentes vegetais e áreas com grande biodiversidade (FF, 2013). Agregando essas características, foram definidas as zonas, o que foi organizado no seguinte quadro pela equipe do Plano de Manejo: 
Quadro 4 - Relação dos critérios com as diferentes zonas.

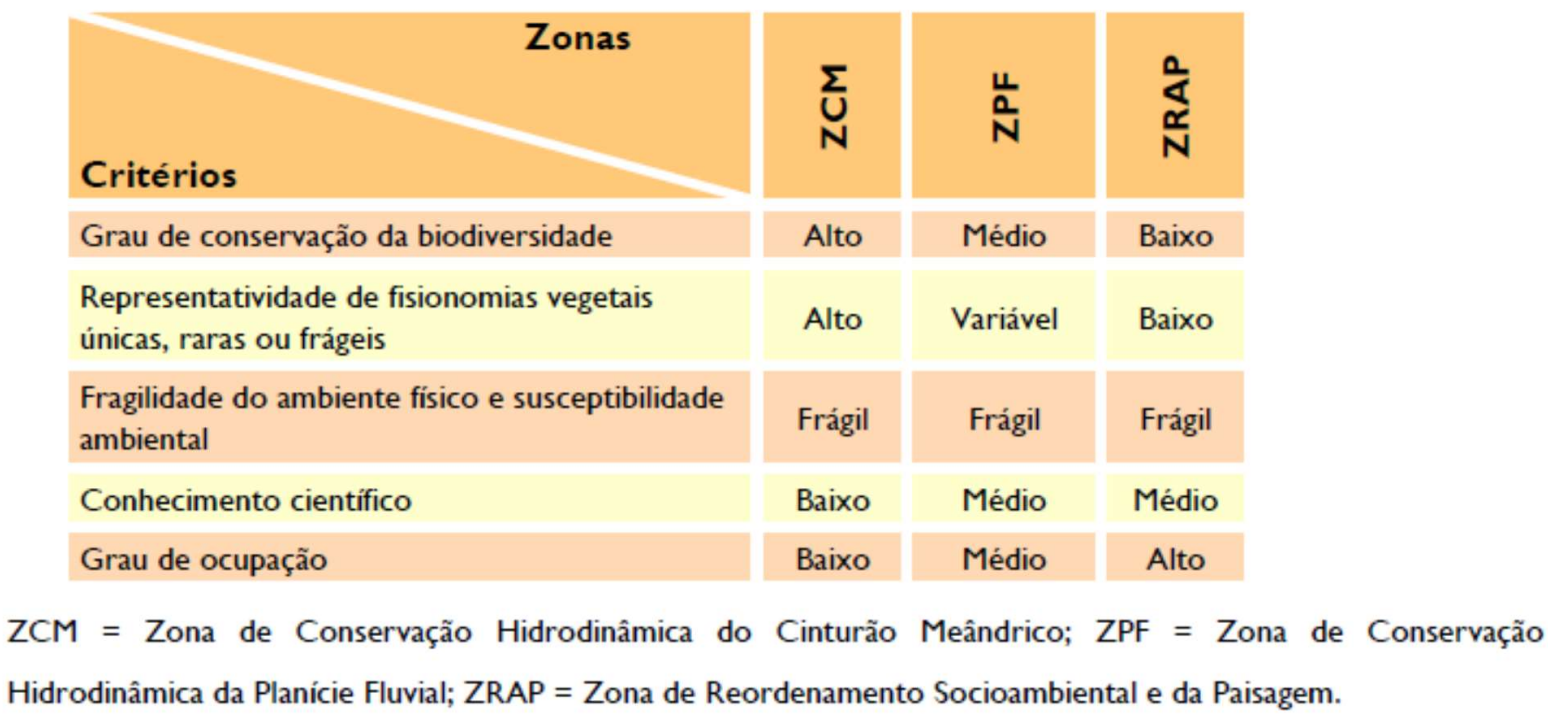

Fonte: FF (2013)

A partir desses critérios, a ZCM é a zona com maior restrição, pois tem o objetivo de preservar a morfologia e a recuperação da vegetação (SÃO PAULO, 2016b). As atividades permitidas e as condicionantes estão descritas no art. 11 da minuta do decreto:

Artigo 11 - São permitidos na ZCM somente, obras, atividades, empreendimentos, usos ou projetos de utilidade pública, interesse social e baixo impacto, assim definidos na lei federal 12.651/2012, excetuadas as atividades de pesquisa e extração de areia, argila, saibro e cascalho, ainda que outorgadas pela autoridade competente.

$\S 1^{\circ}$ Em áreas situadas na ZCM podem ser admitidas atividades, obras ou empreendimentos, desde que observadas as seguintes condições:

I. Tenha o terreno perdido as características geomorfológicas de planície fluvial, em decorrência de ações humanas comprovadamente ocorridas até agosto de 1997; II. Seja reservada para a manutenção ou a recomposição de área verde pelo menos $50 \%$ (cinquenta por cento) da área do imóvel.

$\S 2^{\circ}$ A utilização de área superior a 50\% (cinquenta por cento) do total do imóvel será permitida, desde que obedecidas as seguintes condições:

I. A manutenção, pelo proprietário do imóvel, de outra área verde, na ZCM, equivalente, no mínimo, ao dobro da área excedente ao permitido; 
II. A apresentação, pelo proprietário do imóvel, ao órgão licenciador, quando da solicitação da licença ambiental, da indicação precisa da área de que trata o item acima, com a correspondente proposta do termo de sua recomposição e manutenção.

$\S 3^{\circ}$ - A área proposta para compensação deverá ser averbada, depois de aprovada, no respectivo cartório de registro de imóveis quando se tratar de propriedade privada.

A ZPF também tem o objetivo de proteger a morfologia e promover a recuperação vegetal, mas também se define pela manutenção das atividades e empreendimentos existentes, contanto que compatibilizados com os objetivos da ZPF (SÃO PAULO, 2016b). Nessa zona são permitidas atividades como a agricultura, silvicultura, turismo sustentável, atividades ou empreendimentos de utilidade pública e de baixo impacto e a mineração de areia, argila, saibro e cascalho contanto que atendam às exigências definidas para os licenciamentos (SÃO PAULO, 2016b). Para essas atividades serem mantidas, o terreno tem de ter perdido as características geomorfológicas antes de 1997 e preservado $50 \%$ do terreno. As atividades novas, por outro lado, não podem implicar em aterro, impermeabilização e uso de agroquímicos (SÃO PAULO, 2016b).

O ZRAP, por outro lado, são as áreas com menor restrição e que possuem o objetivo de adequar os usos para atenuar os impactos nas outras zonas e diminuir a vulnerabilidade da população (SÃO PAULO, 2016b). São permitidos os usos urbanos, contanto que se considere a permeabilidade hidrológica, adote soluções de microdrenagem, implementação de áreas verdes e destinação adequada de resíduos e efluentes (SÃO PAULO, 2016b).

Além dos 3 zoneamentos propostos pelo plano de manejo, a proposta da minuta do decreto do Plano de Manejo APAVRT, aprovado pela CTBio em 2016, propõe que se mantenha a Zona de Vida Silvestre do zoneamento vigente. Esse último zoneamento abrange as Áreas de Preservação Permanente e todos os remanescentes de mata atlântica em estágio primário ou secundário e nos estágios médios e avançados (SÃO PAULO, 2016b). A diferença entre a ZVS vigente com a nova estaria nas leis que a fundamentam: a mais antiga se respalda no Decreto Federal 750/1993, enquanto a nova se baseia na lei federal 11428/2006 e na lei federal 12651/2012 (FF, 2013; SÃO PAULO, 2016b). 
No plano, as Áreas Prioritárias são definidas como áreas delimitadas dentro de uma zona que possuem, em razão de suas particularidades, objetivos específicos para recuperação e proteção ambiental (FF, 2013). Foram definidos três tipos de Áreas Prioritárias:

- Área Prioritária de Recuperação Ambiental (APRA). A Área Prioritária de Recuperação Ambiental (APRA) compreende as áreas urbanizadas sobrepostas à ZCM e que deverão ser recuperadas com vistas a minorar o nível crítico da cobertura vegetal existente na APA, garantir a manutenção da conectividade ecológica e dos fluxos gênicos da fauna e da flora local e prevenir situações de risco relativas aos processos de migração lateral do canal. Localizam-se na faixa de $50 \mathrm{~m}$ que margeia o canal fluvial do Rio Tietê que sofreram forte intervenção antropogênica, tais como aterros, retificações, etc. Não se aplicam a ZPF e ZRAP.

- Áreas Prioritárias de Recuperação da Atividade Minerária (ARM). As Áreas Prioritárias de Recuperação da Atividade Minerária (ARM) compreende porções do território, sobrepostas à ZPF e ou ZCM, que foram ou estão sendo submetidas à atividades minerárias, nas quais são geradas cavas, rejeitos e lagoas que deverão ser reconfigurados, recuperados e controlados a partir de seus respectivos Planos de Recuperação de Área Degradada (PRAD) e ou de projetos específicos.

- Áreas Prioritárias de Requalificação Socioambiental e da Paisagem (ARQ). As Áreas Prioritárias de Requalificação Socioambiental e da Paisagem (ARQ) compreende porções do território da APA, sobrepostas à ZRAP, correspondentes aos níveis mais baixos da Planície Fluvial e que se encontram submetidas a usos urbanos e que deverão ser requalificadas de modo a minimizar ou superar situações de risco, de precariedade em infraestrutura, equipamentos urbanos e saneamento ambiental, promovendo a qualidade de vida da população.

O plano foi concluído em 2013 e, até ser aprovado, ficou sob análise entre 2013 e 2017. O plano foi enviado para o CONSEMA, para ser enviado para a Comissão Temática de Biodiversidade, Florestas, Parques e Áreas Protegidas (CTBio), que avaliou o plano e encaminhou para votação na plenária do CONSEMA. No entanto, em dezembro de 2013, foi publicada a portaria SMA 121/2013, que estabelece critérios e diretrizes para o zoneamento e a normatização das APAs. Em janeiro de 2014, o CONSEMA deliberou que o Plano de Manejo deveria ser avaliado e adequado pelo CTBio, considerando a resolução SMA 121/2013 (SMA, 2014).

Posteriormente, em 2017, o plano foi aprovado e em seguida suspenso pela Ação Civil Pública Ambiental e de Improbidade Administrativa pelo Ministério Público do Estado. No Processo 1023452-67.2017.8.26.0053 do ministério público estão documentados os depoimentos e os fatos relativos às alterações da minuta do decreto e adulterações nos mapas 
de zoneamento da APA para favorecer algumas empresas representadas pela FIESP. Como relatado no processo, destaca-se o papel do então secretário Ricardo Salles e dos servidores públicos Roberta Buendia Sabbagh, Danilo Angelucci de Amorim e da antiga gestora da APA Fernanda Lemes, os quais pressionaram os funcionários do setor de geoprocessamento da Fundação Florestal para alterar os mapas de zoneamento. Diante das pressões, da falta de explicações e dos e-mails demonstrando que as alterações não tinham sido aprovadas pelo conselho, o funcionário Victor Godoy se exonerou do cargo e fez denúncia das adulterações no zoneamento do Plano de Manejo.

As adulterações identificadas pelo MPSP no zoneamento da APA foram sintetizadas nos mapas (fig. 15 e 16), com a exceção da figura 14, que apresenta a remoção do rio Tietê nos mapas do zoneamento. Com relação aos mapas, estão realçadas, em vermelho, as áreas que foram alteradas no zoneamento para favorecer as indústrias.

Figura 14 - Remoção do rio no mapa de zoneamento.

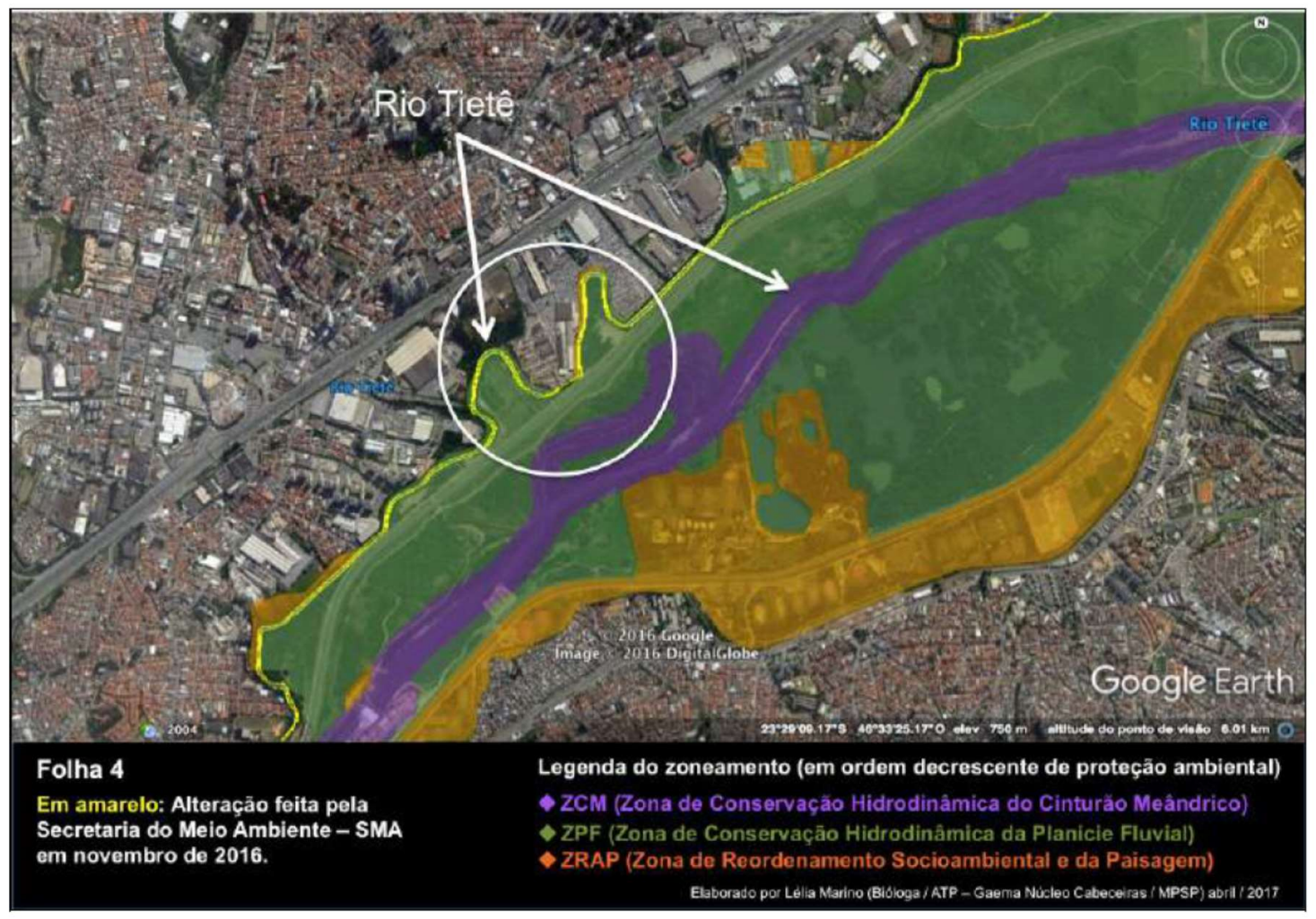

Fonte: MPSP (2017) 
Figura 15 - Mapa das áreas identificadas pelo MPSP como adulteradas

Áreas com o zoneamento aldulterado setor Oeste

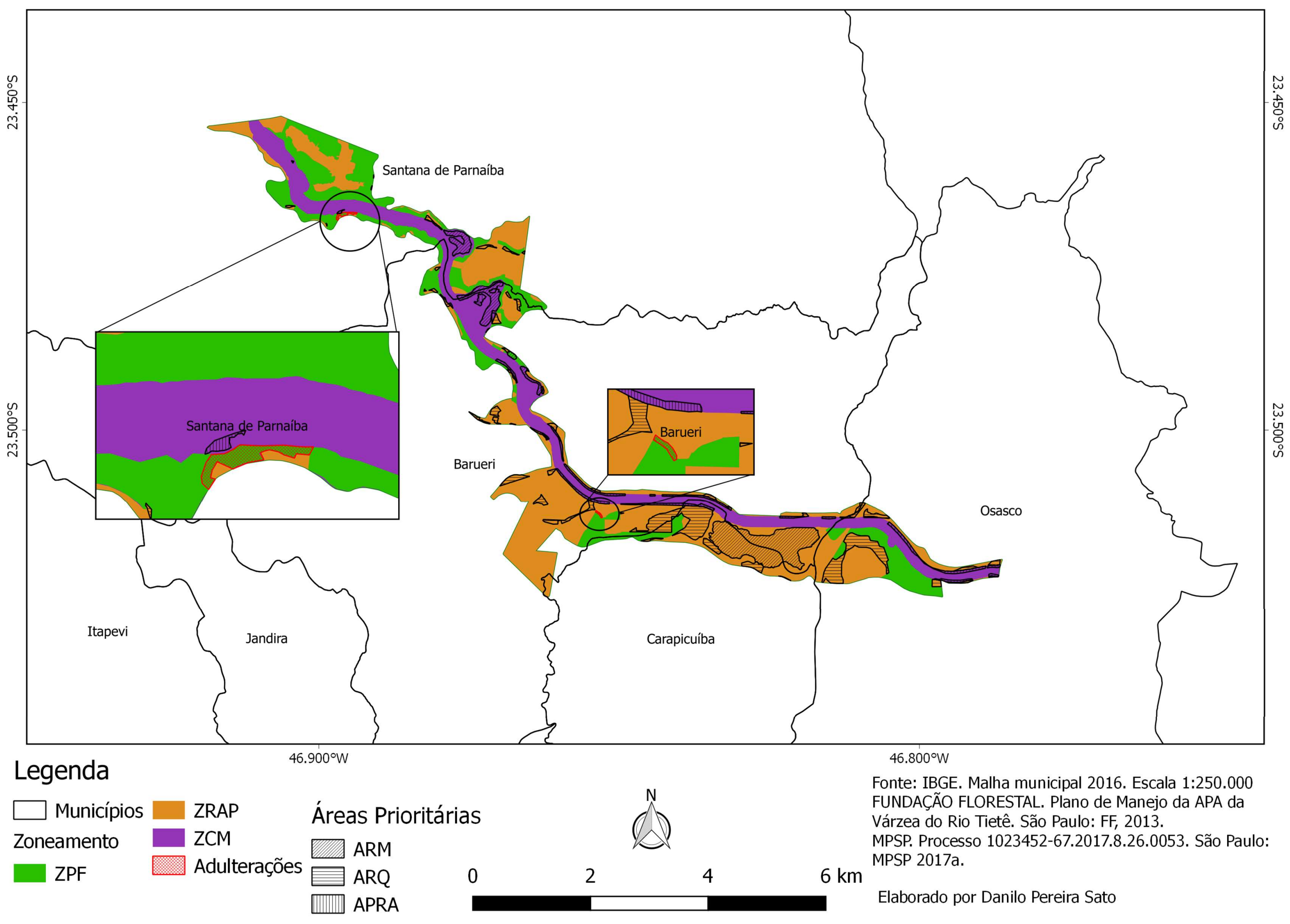

Elaborado pelo autor 
Figura 16 - Mapa das áreas identificadas pelo MPSP como adulteradas

Áreas com o zoneamento aldulterado setor Leste

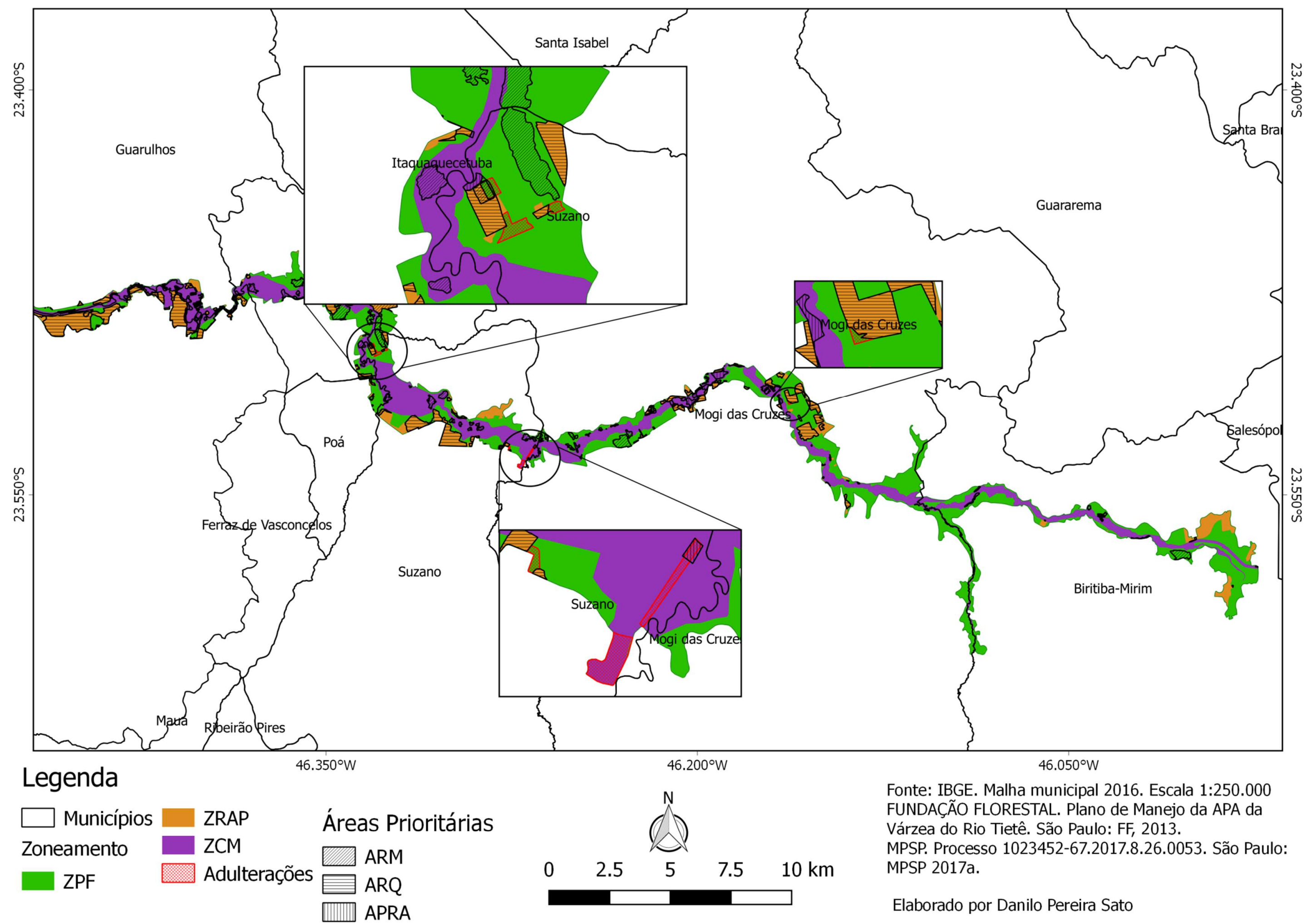

Elaborado pelo autor 
Além das alterações no zoneamento, houve também alterações na Minuta do Decreto que havia sido aprovado pelo CTBio e pelo CONSEMA (MPSP, 2017b). No quadro abaixo há algumas alterações, sistematizadas pelo MPSP, com os artigos que foram alterados ou suprimidos, quando, quais aspectos foram alterados ou inseridos e, por fim, quais são os possíveis impactos.

\begin{tabular}{|c|c|c|c|}
\hline \multicolumn{4}{|c|}{ Caracterização das alterações da minuta de decreto da APA da Várzea do Rio Tietê } \\
\hline $\begin{array}{l}\text { Dispositivos } \\
\text { alterados }\end{array}$ & $\begin{array}{l}\text { Instâncias de } \\
\text { alteração }\end{array}$ & Alterações no texto da minuta & Observações e consequências previstas \\
\hline $\begin{array}{l}\text { Artigo } 2^{\circ} \text { : } \\
\text { supressão de } \\
\text { conceitos e } \\
\text { definições }\end{array}$ & $\begin{array}{l}\text { Gabinete do } \\
\text { Secretário } \\
\text { (versão de } \\
29 / 9 / 2016 \text { ) }\end{array}$ & $\begin{array}{l}\text { Exclui } 52 \text { de } 61 \text { conceitos e } \\
\text { definições básicos da versão da } \\
\text { Fundação Florestal (17/8/2016), que } \\
\text { já excluíra } 13 \text { dos } 74 \text { da versão } \\
\text { original de (11/11/2015). Ao todo } \\
\text { foram } 65 \text { exclusões nas duas etapas. }\end{array}$ & $\begin{array}{l}\text { Função didática do decreto proposto foi } \\
\text { prejudicada pela retirada de quase todos } \\
\text { os conceitos e definições, que passam a } \\
\text { constar apenas no Plano de Manejo, que } \\
\text { é um instrumento muito extenso e } \\
\text { complexo. }\end{array}$ \\
\hline $\begin{array}{l}\text { Artigo } 8^{\circ} \text { : } \\
\text { (art. } 11 \text { na } \\
\text { versão } \\
\text { final): } \\
\text { alteração do } \\
\text { caput }\end{array}$ & $\begin{array}{l}350^{\mathrm{a}} \text { Reunião } \\
\text { do } \\
\text { CONSEMA } \\
\text { em } 31 / 1 / 2017 \\
\text { (versão final, } \\
\text { 2/2/2017) }\end{array}$ & $\begin{array}{l}\text { Introduz exceções para proibições. } \\
\text { Introduz, como ressalvas às } \\
\text { proibições na ZVS, "atividades, } \\
\text { obras, edificações e } \\
\text { empreendimentos (...) referentes ao } \\
\text { Programa Várzeas do Tietê (...)". }\end{array}$ & $\begin{array}{l}\text { Proposta da Secretaria de Saneamento e } \\
\text { Recursos Hídricos, incorporada à } \\
\text { redação final em } 2 / 2 / 2017 \text {, após a } \\
\text { reunião do CONSEMA de } 31 / 1 / 2017 \text {. A } \\
\text { ressalva introduz amparo no decreto } \\
\text { para obras do Programa Várzeas do } \\
\text { Tietê que são objeto de Ação Civil } \\
\text { Pública por dano ambiental (ver } \\
\text { alteração do art. } 3^{\circ} \text {, III). }\end{array}$ \\
\hline $\begin{array}{l}\text { Artigo } 8^{\circ} \text { : } \\
\text { (art. } 11 \text { na } \\
\text { versão } \\
\text { final): } \\
\text { supressão do } \\
\S 1^{\circ}\end{array}$ & $\begin{array}{l}\text { Gabinete do } \\
\text { Secretário } \\
(29 / 9 / 2016)\end{array}$ & $\begin{array}{l}\text { Retira exigência de "inexistência de } \\
\text { alternativa técnica e locacional" } \\
\text { para atividades, empreendimentos, } \\
\text { obras ou edificações considerados } \\
\text { de interesse social e baixo impacto. }\end{array}$ & $\begin{array}{l}\text { Permite iniciativas que, em favor de } \\
\text { maior nível de conservação ambiental e } \\
\text { também atendendo ao interesse social, } \\
\text { poderiam ser realizadas na ZRAP; e } \\
\text { desobriga o empreendedor de recorrer a } \\
\text { técnicas de menor impacto ambiental, } \\
\text { inclusive a possíveis inovações } \\
\text { tecnológicas. }\end{array}$ \\
\hline $\begin{array}{l}\text { Artigo 10: } \\
\text { alteração do } \\
\text { inciso II }\end{array}$ & $\begin{array}{l}\text { Gabinete do } \\
\text { Secretário } \\
(29 / 9 / 2016)\end{array}$ & $\begin{array}{l}\text { Restringe proibição. Proibição de } \\
\text { "parcelamentos do solo para fins } \\
\text { urbanos" passa a ser de "novos } \\
\text { parcelamentos ..." }\end{array}$ & $\begin{array}{l}\text { Possibilita parcelamentos de solo já } \\
\text { autorizados e ainda não implantados. }\end{array}$ \\
\hline $\begin{array}{l}\text { Artigo 10: } \\
\text { alteração do } \\
\text { inciso III }\end{array}$ & $\begin{array}{l}\text { Gabinete do } \\
\text { Secretário } \\
(29 / 9 / 2016)\end{array}$ & $\begin{array}{l}\text { Restringe proibição. A proibição } \\
\text { para "implantação de indústrias ou a } \\
\text { expansão daquelas existentes" é } \\
\text { alterada para "implantação de novas } \\
\text { atividades industriais". }\end{array}$ & $\begin{array}{l}\text { A alteração reduz a proibição prevista } \\
\text { na minuta original, permitindo } \\
\text { expansão das atividades industriais } \\
\text { existente e, consequentemente, de seu } \\
\text { impacto ambiental, contrariando os } \\
\text { objetivos da intenção normativa de } \\
\text { conservação e recuperação do ambiente } \\
\text { natural da ZCM. }\end{array}$ \\
\hline
\end{tabular}




\begin{tabular}{|c|c|c|c|}
\hline $\begin{array}{l}\text { Artigo 10: } \\
\text { supressão do } \\
\text { inciso VII }\end{array}$ & $\begin{array}{l}\text { Gabinete do } \\
\text { Secretário } \\
\text { (versão de } \\
29 / 9 / 2016 \text { ) }\end{array}$ & $\begin{array}{l}\text { Exclui proibição. Retira, das } \\
\text { proibições na ZCM a "supressão } \\
\text { e/ou fragmentação de } \\
\text { remanescentes da vegetação nativa". }\end{array}$ & $\begin{array}{l}\text { Deixa sujeita à discricionariedade da } \\
\text { administração a emissão de } \\
\text { autorizações para supressão e } \\
\text { fragmentação de remanescentes de } \\
\text { vegetação nativa }\end{array}$ \\
\hline $\begin{array}{l}\text { Artigo 10: } \\
\text { supressão do } \\
\text { inciso IX e } \\
\text { do } \S 1^{\circ}\end{array}$ & $\begin{array}{l}\text { Gabinete do } \\
\text { Secretário } \\
\text { (versão de } \\
29 / 9 / 2016 \text { ) }\end{array}$ & $\begin{array}{l}\text { Exclui proibição e obrigação. } \\
\text { Exclui a proibição da implantação } \\
\text { ou ampliação de empreendimentos } \\
\text { minerários e exclui a obrigação de } \\
\text { desenvolver e implantar programas } \\
\text { de gradativa eliminação das } \\
\text { atividades de mineração existentes }\end{array}$ & $\begin{array}{l}\text { Em vez de restringir atividades } \\
\text { geradoras de impacto ambiental, a } \\
\text { alteração permite ampliá-las, } \\
\text { contrariando os objetivos da intenção } \\
\text { normativa de conservação e } \\
\text { recuperação do ambiente natural da } \\
\text { ZCM. }\end{array}$ \\
\hline $\begin{array}{l}\text { Artigo 10: } \\
\text { alteração do } \\
\text { inciso IX e } \\
\text { supressão do } \\
\S 1^{\circ} \text { e } \S 3^{\circ}\end{array}$ & $\begin{array}{l}\text { Gabinete do } \\
\text { Secretário } \\
\text { (versão de } \\
29 / 9 / 2016 \text { ) }\end{array}$ & $\begin{array}{l}\text { Restringe proibição e exclui } \\
\text { obrigação e exigência. Nas } \\
\text { proibições, substitui o termo } \\
\text { "agroquímicos" por "agrotóxicos e } \\
\text { fertilizantes, em desacordo com as } \\
\text { normas vigentes"; suprime } \\
\text { obrigação de implantar programas } \\
\text { de gradativa eliminação de } \\
\text { agroquímicos; e suprime a } \\
\text { exigência de receituário específico e } \\
\text { justificativo para agroquímicos } \\
\text { enquanto não for eliminado o uso } \\
\text { desses produtos. }\end{array}$ & $\begin{array}{l}\text { A substituição do termo permite o uso } \\
\text { indiscriminado de corretivos agrícolas. } \\
\text { (Obs. São abrangidos no conceito de } \\
\text { agroquímicos da definição II do artigo } \\
2^{\circ} \text {, que já havia sido excluída da } \\
\text { proposta original pelo NPM/FF (ver } \\
\text { alteração do art. } 2^{\circ} \text { ). As supressões } \\
\text { descartam o cumprimento do objetivo } \\
\text { da intenção normativa de impedir } \\
\text { completamente na ZCM em um futuro } \\
\text { próximo os impactos de agrotóxicos, } \\
\text { fertilizantes e corretivos agrícolas. }\end{array}$ \\
\hline $\begin{array}{l}\text { Artigo 10: } \\
\text { supressão do } \\
\text { inciso XII }\end{array}$ & $\begin{array}{l}\text { Gabinete do } \\
\text { Secretário } \\
\text { (versão de } \\
29 / 9 / 2016 \text { ) }\end{array}$ & $\begin{array}{l}\text { Exclui proibição. Suprime a } \\
\text { proibição na ZCM do cultivo de } \\
\text { produtos transgênicos e de espécies } \\
\text { exóticas com potencial de } \\
\text { bioinvasão. }\end{array}$ & $\begin{array}{l}\text { As supressões põem em risco o } \\
\text { objetivo de manter e recuperar a } \\
\text { diversidade biológica da ZCM (art. 10, } \\
\text { II). A retirada da vedação de } \\
\text { transgênicos é reiterado pelo acréscimo } \\
\text { do artigo } 31 \text {. }\end{array}$ \\
\hline $\begin{array}{l}\text { Artigo 10: } \\
\text { acréscimo } \\
\text { do } \S 5^{\circ}\end{array}$ & $\begin{array}{l}\text { Gabinete do } \\
\text { Secretário } \\
\text { (versão de } \\
29 / 9 / 2016 \text { ) }\end{array}$ & $\begin{array}{l}\text { Introduz normas para o que deixou } \\
\text { de proibir. Estabelece normas para } \\
\text { cultivos existentes e novos de } \\
\text { espécies invasoras, cuja proibição } \\
\text { foi excluída (ver alteração anterior). }\end{array}$ & $\begin{array}{l}\text { Além de reforçar o fim da proibição } \\
\text { desse tipo de cultivos, o acréscimo } \\
\text { também estimula novos cultivos, } \\
\text { trazendo prejuízo para o objetivo da } \\
\text { proposta inicial de manter e recuperar a } \\
\text { biodiversidade da ZCM }\end{array}$ \\
\hline $\begin{array}{l}\text { Artigo 11: } \\
\text { supressão do } \\
\text { inciso I }\end{array}$ & $\begin{array}{l}\text { Gabinete do } \\
\text { Secretário } \\
\text { (versão de } \\
29 / 9 / 2016 \text { ) }\end{array}$ & $\begin{array}{l}\text { Exclui exigência para obras e } \\
\text { atividades. Retirada da exigência de } \\
\text { comprovação de alternativa técnica } \\
\text { e locacional para atividades, } \\
\text { empreendimentos, obras ou } \\
\text { quaisquer edificações considerados } \\
\text { de interesse social e baixo impacto. }\end{array}$ & $\begin{array}{l}\text { Submete a ZCM à implantação de } \\
\text { iniciativas que, em favor de maior nível } \\
\text { de conservação ambiental e também } \\
\text { atendendo ao interesse social, poderiam } \\
\text { ser realizadas em áreas de ZRAP; e } \\
\text { desobriga o empreendedor de recorrer a } \\
\text { técnicas de menor impacto ambiental, } \\
\text { inclusive a possíveis inovações } \\
\text { tecnológicas. }\end{array}$ \\
\hline
\end{tabular}




\begin{tabular}{|c|c|c|c|}
\hline $\begin{array}{l}\text { Artigo 13: } \\
\text { supressão do } \\
\S 1^{\circ}\end{array}$ & $\begin{array}{l}\text { Gabinete do } \\
\text { Secretário } \\
\text { (versão de } \\
\text { 29/9/2016) }\end{array}$ & $\begin{array}{l}\text { Exclui exigência de comprovação } \\
\text { de alternativa técnica e locacional } \\
\text { para atividades, empreendimentos, } \\
\text { obras ou quaisquer edificações } \\
\text { considerados de interesse social e } \\
\text { baixo impacto. }\end{array}$ & $\begin{array}{l}\text { Submete a ZPF à implantação de } \\
\text { iniciativas que, em favor de maior nível } \\
\text { de conservação ambiental e também } \\
\text { atendendo ao interesse social, poderiam } \\
\text { ser realizadas em áreas de ZRAP; e } \\
\text { desobriga o empreendedor de recorrer a } \\
\text { técnicas de menor impacto, inclusive a } \\
\text { possíveis inovações tecnológicas. }\end{array}$ \\
\hline $\begin{array}{l}\text { Artigo 13: } \\
\text { alteração do } \\
\text { caput e } \\
\text { acréscimo } \\
\text { do } \S 3^{\circ}\end{array}$ & $\begin{array}{l}\text { Gabinete do } \\
\text { Secretário } \\
\text { (versão de } \\
29 / 9 / 2016 \text { ) }\end{array}$ & $\begin{array}{l}\text { Introduz permissão para para } \\
\text { exploração de areia, argila, saibro e } \\
\text { cascalho, com critérios definidos } \\
\text { por resolução conjunta entre a } \\
\text { Secretaria do Meio Ambiente e a } \\
\text { Secretaria de Energia e Mineração, } \\
\text { e aplicados pela Cetesb no âmbito } \\
\text { do licenciamento ambiental. }\end{array}$ & $\begin{array}{l}\text { A introdução foi viabilizada por duas } \\
\text { alterações: retirada do termo } \\
\text { "ambiental" no trecho sobre a } \\
\text { permissão de "obras, atividades, } \\
\text { empreendimentos, usos ou projetos de } \\
\text { utilidade pública, interesse social ou de } \\
\text { baixo impacto ambiental"; e inserção de } \\
\text { referência à lei } 12.651 / 2012 \text {, que define } \\
\text { essas atividades como sendo de } \\
\text { utilidade pública (art. } 3^{\circ}, \text { VIII, b) e de } \\
\text { interesse social (art. } 3^{\circ}, \text { IX, f). Sobre a } \\
\text { palavra "ambiental" removida, vale } \\
\text { observar que a citada lei não inclui tais } \\
\text { atividades entre as que define como de } \\
\left.\text { baixo impacto ambiental (art. } 3^{\circ}, X\right) \text {. }\end{array}$ \\
\hline $\begin{array}{l}\text { Artigo 13: } \\
\text { supressão do } \\
\S 3^{\circ}\end{array}$ & $\begin{array}{l}350^{\mathrm{a}} \text { Reunião } \\
\text { do } \\
\text { CONSEMA } \\
\text { em } 31 / 1 / 2017 \\
\text { (versão } \\
\text { final,2/2/2017) }\end{array}$ & $\begin{array}{l}\text { Exclui obrigação normativa. Retira } \\
\text { previsão de definição de critérios } \\
\text { para licenciamento de atividades de } \\
\text { exploração de areia, argila, saibro e } \\
\text { cascalho por meio de resolução } \\
\text { conjunta da Secretaria do Meio } \\
\text { Ambiente e da Secretaria de Energia } \\
\text { e Mineração, e de eles serem } \\
\text { aplicados pela Cetesb no âmbito do } \\
\text { licenciamento ambiental }\end{array}$ & $\begin{array}{l}\text { Ao propor a supressão do } \S 3^{\circ} \text {, a } \\
\text { Secretaria de Energia e Mineração } \\
\text { alegou que "não há razão para se criar } \\
\text { novos critérios uma vez já estarem } \\
\text { vigentes procedimentos para outorga e } \\
\text { licenciamento". Supressão da } \\
\text { atribuição normativa conjunta da SEM } \\
\text { e da SMA agrava a vulnerabilização } \\
\text { ambiental da ZPF já ocorrida com } \\
\text { retirada da proibição das atividades de } \\
\text { exploração de areia, argila, saibro e } \\
\text { cascalho. }\end{array}$ \\
\hline $\begin{array}{l}\text { Artigo 15: } \\
\text { alteração do } \\
\text { inciso V e } \\
\text { supressão do } \\
\S 2^{\circ} \text { e } \S 3^{\circ}\end{array}$ & $\begin{array}{l}\text { Gabinete do } \\
\text { Secretário } \\
\text { (versão de } \\
29 / 9 / 2016 \text { ) }\end{array}$ & $\begin{array}{l}\text { Restringe proibição e exclui } \\
\text { obrigação e exigência. Nas } \\
\text { proibições, substitui o termo } \\
\text { "agroquímicos" por "agrotóxicos e } \\
\text { fertilizantes, em desacordo com as } \\
\text { normas vigentes"; suprime } \\
\text { obrigação de implantar programas } \\
\text { de gradativa eliminação de } \\
\text { agroquímicos; e suprime a } \\
\text { exigência de receituário específico e } \\
\text { justificativo para agroquímicos } \\
\text { enquanto não for eliminado o uso } \\
\text { desses produtos. }\end{array}$ & $\begin{array}{l}\text { A substituição do termo permite o uso } \\
\text { indiscriminado de corretivos agrícolas. } \\
\text { Obs.: são abrangidos no conceito de } \\
\text { agroquímicos da definição II do artigo } \\
2^{\circ} \text {, que já havia sido excluída da } \\
\text { proposta original pelo NPM/FF (ver } \\
\text { alteração do art. } 2^{\circ} \text { ). As supressões } \\
\text { descartam o cumprimento do objetivo } \\
\text { da intenção normativa de impedir } \\
\text { completamente na ZCM em um futuro } \\
\text { próximo os impactos de agrotóxicos, } \\
\text { fertilizantes e corretivos agrícolas. }\end{array}$ \\
\hline
\end{tabular}




\begin{tabular}{|c|c|c|c|}
\hline $\begin{array}{l}\text { Artigo } 31 \\
\text { acrescentado }\end{array}$ & $\begin{array}{l}\text { Gabinete do } \\
\text { Secretário } \\
\text { (versão de } \\
29 / 9 / 2016 \text { ) }\end{array}$ & $\begin{array}{l}\text { Proíbe restrições a transgênicos na } \\
\text { APA. }\end{array}$ & $\begin{array}{l}\text { A proibição de transgênicos, prevista } \\
\text { originalmente na versão da CTBio de } \\
11 / 11 / 2015 \text {, foi excluída pelo Gabinete } \\
\text { do Secretário com a supressão do } \\
\text { Artigo } 10 \text {, II. O acréscimo do artigo } 31 \\
\text { expande a proibição para organismos } \\
\text { geneticamente modificados, salvo as } \\
\text { fixadas por decisão da Comissão } \\
\text { Técnica Nacional de Biossegurança. O } \\
\text { acréscimo estimula cultivos } \\
\text { transgênicos, trazendo prejuízo para o } \\
\text { objetivo da proposta inicial de manter e } \\
\text { recuperar a biodiversidade da ZCM. }\end{array}$ \\
\hline
\end{tabular}

Fonte: MPSP (2017b)

Nos quadros, destaca-se, de modo geral, a diminuição das restrições ambientais, das atividades econômicas, tornando mais fácil o licenciamento. Diversos setores vão ser atendidos, como setores ligados à mineração, agricultura, indústrias já instaladas e mesmo o setor imobiliário. Um dos pontos que se destaca é a inclusão da mineração, a despeito de ser registrada nos debates a oposição da Fundação Florestal e das críticas dos professores Cleide Rodrigues e Jurandyr Ross a essa inclusão (MPSP, 2017). Outro elemento de destaque foi o favorecimento do Programa Várzeas do Tietê, incluído como exceção às restrições de uso no zoneamento (MPSP, 2017b).

Após a denúncia e o começo do inquérito do MPE, Ricardo Salles iniciou uma sindicância para averiguar as pressões que os funcionários alegavam (GIRARDI, 2017a; MPSP; 2017b). Essa sindicância foi interpretada como uma forma de intimidar os funcionários pelo MPE, além de ser comandada pelo ouvidor da secretaria, Roberto Pitaguari Germanos, que tem grande proximidade política com Ricardo Salles, e o secretário-adjunto Antonio Velloso Carneiro, também investigado (juntamente com Ricardo Salles) por lavagem de dinheiro e uso da SMA em benefício próprio (GIRADI, 2017; MPSP, 2017b).

Outro fator preponderante neste processo foi a alteração nas esferas de governança. A composição do CONSEMA foi alterada, a qual, segundo Ricardo Salles, era "ambientalista demais" e teria corrigido esse problema, colocando representantes de outras secretarias as quais não estavam representadas no conselho. Após essa alteração do CONSEMA, também foi extinto o conselho gestor da APAVRT, eliminando a consulta à comunidade local quanto às alterações no Plano de Manejo. As alterações e dificuldades na participação social não foram problemas exclusivos da APAVRT. Durante a gestão de Ricardo Salles diversas 
unidades tiveram problemas em seus conselhos, que, em alguns casos, foram reduzidos ${ }^{18}$, suspensos ${ }^{19}$ ou não implementados ${ }^{20}$ por falta de uma diretiva do secretário. Na imprensa, foi noticiado, inclusive, que existiria uma recomendação do Ricardo Salles para que os conselhos funcionassem com o número mínimo permitido pela lei (ESCOBAR, 2017). Ao ser questionado sobre essa postura, o secretário respondeu que a questão era tornar mais “eficientes" os conselhos, além de acusar os conselhos de serem tomados ideologicamente por grupos contrários ao mercado e ao desenvolvimento (ESCOBAR, 2017).

A classificação dos atores institucionais de Cahn (1995), em que se separa o corpo burocrático do gestor responsável, é conveniente para a presente análise, pois é evidente uma relação conflituosa entre o então secretário com os funcionários, como já mencionado e expresso com a Carta Aberta da Associação dos Pesquisadores Científicos do Estado de São Paulo, além dos embates com o Ministério Público Estadual.

Por fim, o Plano de Manejo foi anulado pelo Ministério Público em junho de 2018, pois foram constatadas as adulterações em favor do setor da mineração, (LARA, 2018), implicando na manutenção do zoneamento de 1998 e a ausência de um plano de manejo.

\section{5 - Programa Várzeas do Tietê (PVT)}

O PVT é um programa retomado em 2009, baseado no Programa de Recuperação das Várzeas da Bacia Alto Tietê, concebido por Burle Marx em 1974, e encabeçado por Ruy Othake (FF, 2013). Este programa tem como objetivo a recuperação das várzeas do Rio Tietê, com um parque que se inicia em São Paulo e se estende até a nascente, em Salesópolis,

\footnotetext{
${ }^{18} \mathrm{O}$ caso da Floresta Estadual Edmundo Navarro de Andrade no qual era composto inicialmente por 18 representantes e passou para 8 representantes dos quais 3 são da Fundação Florestal e 1 de entidade ambientalista. Informação obtida presencialmente em reunião do CONSEMA e disponível na Ata da $352^{\mathrm{a}}$ Reunião Ordinária do Plenário do Conselho Estadual do Meio Ambiente e em matéria do Estadão de Herton Escobar no dia 22 de março de 2017.

${ }^{19}$ Caso do Conselho da Estação Ecológica de Santa Bárbara que foi criado para a aprovação do plano de manejo e logo em seguida foi suspenso. Informação obtida durante a apresentação de Natalí de Gregorio durante o 25 Simpósio Internacional de Iniciação Científica e Tecnológica da USP.

${ }^{20}$ Situação em que o secretário passou um ano sem liberar a diretiva para a composição dos conselhos impedindo a chamada pública para a composição do conselho. Informação oral obtida do Gestor do Parque Estadual da Cantareira durante o II Seminário A Dimensão Social da Formação Profissional e do I Fórum Integrado da Zona de Amortecimento do Parque Estadual da Cantareira.
} 
passando pelo território de 10 municípios, totalizando $75 \mathrm{~km}$ e uma área de $107 \mathrm{~km}^{2}$ (DAEE, 2010) com os seguintes elementos no programa:

i) Obras: que inclui movimentos de solos, obras estruturais (pontes, barragens de contenção, canais, proteção de taludes etc.), implantação de núcleos de lazer, vias e ciclovias, reflorestamento e recuperação de áreas degradadas.

ii) Reassentamento: remoção e reassentamento das famílias residentes em situação de risco por inundações;

iii) Sustentabilidade ambiental e social: envolve o fortalecimento das instituições envolvidas, educação ambiental, recomposição da mata ciliar e implantação de unidades de conservação de acordo com o Sistema Nacional de Áreas Protegidas (SNUC). (DAEE, 2010, p. 7)

No projeto de reassentamento, estava previsto o deslocamento de 10.000 famílias e estima-se que 75\% delas se encontram em São Paulo (DAEE, 2010). Este volume acarreta uma mudança na configuração da ocupação na APA, além de suscitar conflitos com a população.

O PVT, em uma consulta prévia à SMA, protocolizada pelo DAEE, foi dispensado da realização do Licenciamento Ambiental e foi condicionado que se atendesse e se fiscalizasse os programas ambientais (CETESB, 2010; HOLTZ, 2015). No parecer da CETESB, o programa é bem avaliado por ser proposta a diminuição da ocupação das planícies de inundação com o programa de reassentamento e está registrado que houve um parecer favorável dado ao PVT em 2009 (CETESB, 2020), período anterior à elaboração ao plano de manejo e que se verificariam depois conflitos quanto ao plano e ao projeto do parque linear.

Originalmente, o prazo de execução era até 2020, mas, em 2013, o projeto foi remanejado com relação aos prazos e a abrangência do projeto, reduzindo as obras e a área de intervenção, contudo mantendo a meta de famílias reassentadas (HOLTZ, 2015). Na tabela abaixo, encontram-se as variações realizadas no projeto do PVT. 
Quadro 6 - Novas quantidades previstas no Contrato de Empréstimo

\begin{tabular}{|c|c|c|c|c|}
\hline \multirow[t]{3}{*}{ Componentes } & \multirow[t]{2}{*}{ Unidade } & \multicolumn{2}{|c|}{ Quantidades } & \multirow[t]{2}{*}{ Variação } \\
\hline & & Originais & Atuais & \\
\hline & & De & Para & \\
\hline \multicolumn{5}{|l|}{ 1. Obras } \\
\hline Via Parque Guarulhos & $\mathrm{Km}$ & 23 & 8 & -15 \\
\hline Ciclovia Guarulhos & $\mathrm{Km}$ & 23 & 16 & -7 \\
\hline Pontes de pequeno porte & unidades & 3 & 3 & 0 \\
\hline $\begin{array}{l}\text { Remoção e disposição de resíduos } \\
\text { retirados das margens do rio }\end{array}$ & $\mathrm{m}^{3}$ & 1.150 .000 & 160.000 & -990.000 \\
\hline Recuperação de áreas ribeirinhas & há & 110 & 16 & -94 \\
\hline Sistema de macrodrenagem & $\mathrm{Km}$ & 2 & 2 & 0 \\
\hline Implantação de núcleos de lazer & unidades & 3 & 3 & 0 \\
\hline Equipamentos de núcleos de lazer & unidades & 169 & 75 & -94 \\
\hline \multicolumn{5}{|l|}{ 2. Reassentamento } \\
\hline Familias em ocupação irregular (Guarulhos) & unidades & 500 & 500 & 0 \\
\hline \multicolumn{5}{|l|}{ 3. Sustentabilidade ambiental e social } \\
\hline Aumento de áreas vegetadas & há & 125 & 57 & -69 \\
\hline
\end{tabular}

Fonte: Holtz (2015).

Destaca-se que há uma redução considerável da extensão do projeto, ficando restrito a São Paulo e Guarulhos, além do projeto ter um caráter prioritário de reassentamento. A recuperação da planície de inundação perde importância com a redução drástica da remoção de resíduos das margens (86\%), da recuperação de áreas ribeirinhas (85\%) e das áreas a serem vegetadas $(54 \%)$.

No relatório, é apresentado que havia uma sinergia entre os interesses da APA, em que o PVT era visto como positivo para a preservação da APA e que, posteriormente, houve desacordo entre o zoneamento proposto e as obras do PVT (HOLTZ, 2015). Como solução, o DAEE propôs as seguintes alterações: 
Quadro 7 - Conflitos entre a APA e o PVT

\begin{tabular}{|c|c|c|c|}
\hline \multicolumn{4}{|c|}{ Plano de Manejo APA PVT } \\
\hline Zonas & $\begin{array}{c}\text { Zona de conservação } \\
\text { hidrodinâmica do cinturão } \\
\text { meândrico } \\
\text { ZCM }\end{array}$ & $\begin{array}{c}\text { Zona de conservação } \\
\text { hidrodinâmica da Planície } \\
\text { fluvial } \\
\text { ZPF }\end{array}$ & $\begin{array}{c}\text { Zona de reordenamento } \\
\text { socioambiental e da } \\
\text { paisagem } \\
\text { ZRAP }\end{array}$ \\
\hline ra & $\begin{array}{c}\text { Via Parque } \\
\text { Ciclovia } \\
\text { Núcleos } \\
\end{array}$ & $\begin{array}{l}\text { Via Parque } \\
\text { Ciclovia } \\
\text { Núcleos }\end{array}$ & $\begin{array}{c}\text { Núcleos } \\
\text { Remoçöes }\end{array}$ \\
\hline $\begin{array}{c}\text { Restrição } \\
\text { APA }\end{array}$ & $\begin{array}{c}\text { Aterros -alteamento } \\
\text { Supressão fragmentação } \\
\text { espécie nativa } \\
\text { Infraestrutura para atividade } \\
\text { esportiva }\end{array}$ & $\begin{array}{c}\text { Aterros -alteamento } \\
\text { Supressão fragmentação } \\
\text { espécie nativa } \\
\text { Infraestrutura para atividade } \\
\text { esportiva }\end{array}$ & $\begin{array}{l}\text { Possibilita a permanência e } \\
\text { regularização das habitações } \\
\text { de interesse social }\end{array}$ \\
\hline $\begin{array}{l}\text { Sugestão } \\
\text { DAEE }\end{array}$ & $\begin{array}{c}\text { Inserir o Art } 8 \text {, al A, B e D "a } \\
\text { exceção de obras e projetos que } \\
\text { restaurem e/ou recuperem as } \\
\text { várzeas e a capacidade de } \\
\text { absorção das águas nas } \\
\text { mesmas" }\end{array}$ & $\begin{array}{l}\text { Inserir o Art 12, al A, B e C } \\
\text { "a exceção de obras e } \\
\text { projetos que restaurem e/ou } \\
\text { recuperem as várzeas e a } \\
\text { capacidade de absorção das } \\
\text { águas nas mesmas" }\end{array}$ & 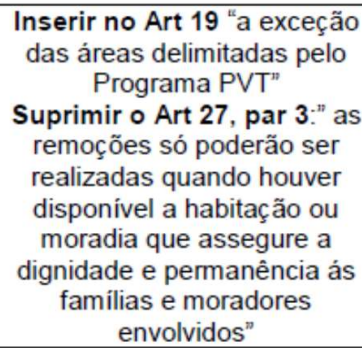 \\
\hline
\end{tabular}

Fonte: Holtz (2015).

Scatena (2015), analisando a sobreposição de planejamentos, observa o aspecto crítico de articular a APA, o PVT e o Hidroanel. Em sua pesquisa, o autor observa que tanto o PVT como o Hidroanel estão considerados e articulados; no entanto, o conjunto das obras previstas é de difícil compatibilização. Rodrigues (2015) observa que existem inconsistências em que as obras implicaram no aterramento de áreas da várzea, a despeito da APA e do PVT também ter como objetivo a preservação das várzeas.

\section{6 - Rodoanel Trecho Leste}

O Rodoanel, trecho leste, perpassa a planície de inundação do rio Tietê nos municípios de Poá, Suzano e Itaquaquecetuba, recortando o território da APA. Nos outros trechos, apresenta diversos impactos socioambientais e, consequentemente, há um prognóstico negativo também para o setor leste (FF, 2013). Iacovini (2003) verifica que o projeto e o traçado para o Rodoanel são baseados em diversos outros projetos antigos para a São Paulo como do DER em 1965, da CDHU em 1989 e diversas propostas da DERSA entre 1991 e 1994. O projeto do Rodoanel é analisado como decorrente e baseado no sistema radioconcêntrico do Plano de Avenidas e figurou como um dos projetos prioritários no PITU 
2020 (STM, 1999; IACOVINI, 2003). No esquema abaixo, do PITU 2020, estão representados os sistemas radioconcêntricos da cidade e a proposta do Rodoanel.

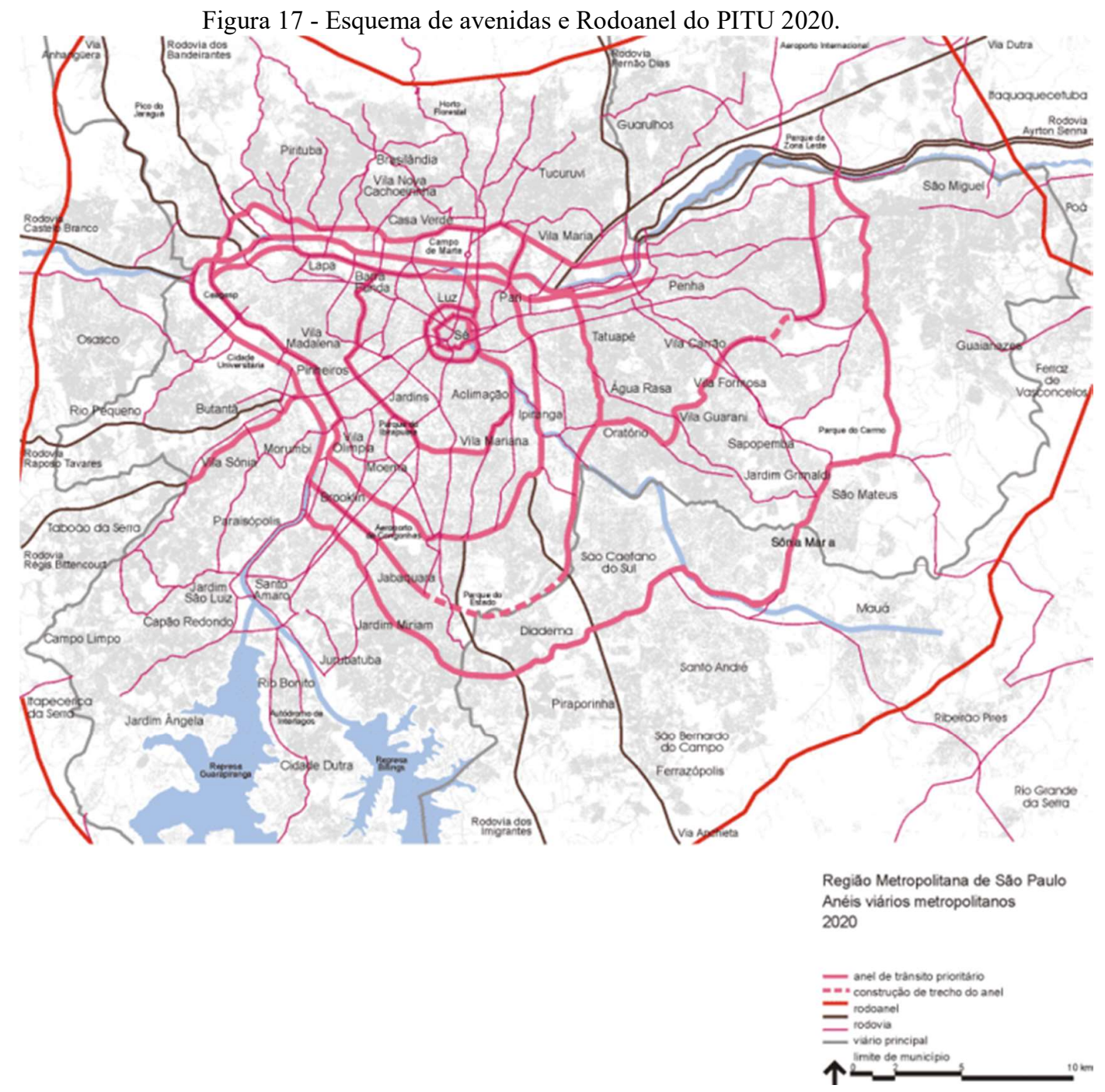

Fonte: STM (1999)

Em razão do Rodoanel ser uma solução escolhida para demonstrar a modernidade de São Paulo antes que se inserisse na agenda esta questão, o projeto atual está associado ao processo de garbage can ${ }^{21}$ (IACOVINI, 2013).

\footnotetext{
${ }^{21}$ Modelo de políticas públicas em que questiona as etapas sequenciais de formação de uma política pública em problema, solução, decisão e execução. Nesse modelo, as etapas são simultâneas ou algumas etapas que seriam posteriores antecedem as demais (MASSARDIER, 2003).
} 
O planejamento deste projeto teve como um dos seus fundamentos uma Avaliação Ambiental Estratégica para respaldar a execução e as alternativas para o Rodoanel. $\mathrm{O}$ trecho leste ficou a encargo da empresa Concessionária SPMAR S/A. As obras começaram em 2011 e foi concluído em 2015 com uma extensão de 43,8 km (LEITE, 2015b).

No parecer do grupo de trabalho de empreendimentos/licenciamentos $n^{\circ} 3 / 2013$ do conselho gestor da APA está expressa a preocupação com os caminhos de serviço da obra do Rodoanel, que poderia implicar na ocupação desses caminhos e assentamento em áreas de uso restritivo. No parecer, foi exigida o monitoramento dos caminhos de serviço, assim como a remoção desses caminhos quando concluíssem as obras. A área em questão foi verificada temporalmente no Google Earth, representada na imagem abaixo: 
Figura 18 -Entorno do caminho de serviço na APA no período 2012-2018

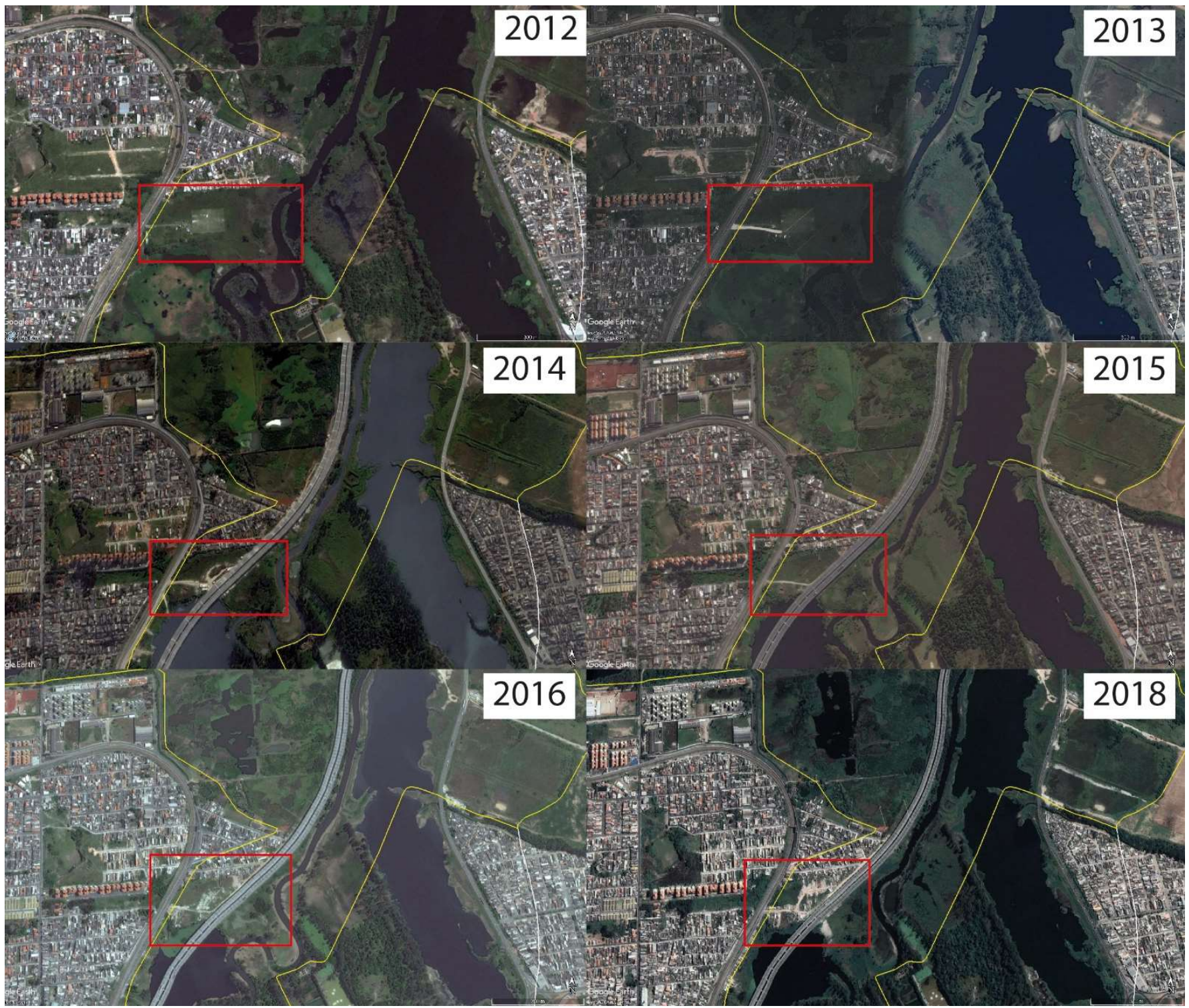

Elaborado pelo o autor

$\mathrm{Na}$ imagem acima, a área em amarelo representa os limites da ZCM (área com grande restrição de uso) e em vermelho a área do entorno de um dos caminhos de serviço do Rodoanel na APAVRT. Verifica-se pela imagem a criação do caminho, as execuções das obras, o abandono do caminho e a subsequente ocupação do entorno a partir de 2016 até o presente. 


\section{7 - Hidroanel Metropolitano de São Paulo}

O estudo do Hidroanel Metropolitano de São Paulo foi licitado em 2009 pelo governo estadual e o Grupo Metrópole Fluvial da FAU-USP, que foi convidado pelo Departamento Hidroviário a participar no estudo de pré-viabilidade técnica (SELT, 2011; SVMA, 2012). O estudo foi finalizado em 2011 e segue as diretrizes da Política Nacional de Recursos Hídricos (L9433/1997), a Política Nacional de Mobilidade Urbana (L12587/2012) ${ }^{22}$ e procura articular a Política Nacional de Resíduos Sólidos (L12305/2010). O projeto tem como meta a sua conclusão até 2040 e está incluído na cartela de ações do Plano de Ação da Macrométropole 2013-2040 da EMPLASA (EMPLASA, 2014).

A origem do projeto do Hidroanel tem como base a dissertação de mestrado do Alexandre Delijaicov (1998), líder do grupo Metrópole Fluvial, que elaborou o projeto. O Hidroanel foi projetado para aproveitar o rio Pinheiro, o Tamanduaté́, trecho do rio Tietê e as represas Billings, Guarapiranga e Taiaçupeba (SELT, 2011a). Posteriormente, durante a execução dos estudos técnicos de viabilidade em conjunto com o IPT e a Escola Politécnica da USP, foi incluída a represa Guarapiranga no projeto (SVMA, 2012). O projeto se sobrepõe a área da APA, nos seguintes trechos:

\footnotetext{
A partir do termo de referência (concorrência DH - 008/2009) o Hidroanel Metropolitano foi dividido em seis trechos. $\mathrm{O}$ trecho 1 do canal navegável do rio Tietê já é navegável nos seus $41 \mathrm{~km}$ de extensão, de montante da barragem de Edgard de Souza, no município de Santana do Parnaíba, à barragem da Penha. O trecho 2 do rio Tietê vai da barragem da Penha à Foz do Taiaçupeba-Açu. (SELT, 2011a, p. 52)
}

Para os dois trechos estão previstos 2 Tri-portos, 7 Trans-portos e 18 Eco-portos, entre obras de adequação, inundação de lagos, reestruturação dos bairros que estiverem na área de influência do projeto e a necessidade de articular com a nova linha 13 de trem da CPTM (SELT, 2011b).

\footnotetext{
22 Destaca-se que o documento tem como data de publicação 2011, mas tem como uma das referências a Política Nacional de Mobilidade Urbana, que seria aprovada em 2012.
} 
Está previsto como função de transporte de carga principal o transporte de resíduos sólidos (do material dragado do rio para a obra, os resíduos coletados na metrópole e o lodo das estações de tratamento de água e de esgoto), e os resíduos aproveitado pela triagem (SELT, 2011a). Há também a possibilidade de, posteriormente, o transporte de gêneros hortifrutigranjeiros, material de construção e o transporte de passageiros (SELT, 2011a). Outro aspecto que se destaca é a previsão de aproveitamento energético associado às eclusas e barreiras (SELT, 2011a)

As diversas alternativas tecnológicas e de projeto se apoiam na perspectiva de redução da emissão de gases de efeito estufa, utilização de outros modais de transporte e integração destes para reduzir a sobrecarga no sistema rodoviário, na logística reversa, na ecologia industrial, na recuperação dos rios em longo prazo e em uma metrópole fluvial (SELT, 2011a). Dessa maneira, o Hidroanel é apresentado e fundamentado nos argumentos de uma sustentabilidade ambiental e tem como um dos propósitos uma mudança de paradigma, com os rios da cidade a partir de uma nova relação com os rios.

As seguintes imagens contêm a localização dessas intervenções e destaca-se que existem grandes áreas a serem inundadas ao longo da APA. No memorial descritivo estão descritas as áreas alagadas propostas (área alagada total do projeto menos a área existente), a área de margem e de entorno (faixa de construção e manutenção da infraestrutura associada ao canal fluvial) e a área total de intervenção (soma das áreas propostas e de margem e de entorno) (SELT, 2011b). 
Tabela 3 - Área de intervenção e área alagada proposta - série 100 e série 200

\begin{tabular}{|c|c|c|c|c|}
\hline & Trecho & $\begin{array}{l}\text { Área } \\
\text { alagada } \\
\text { proposta } \\
\text { (ha) }\end{array}$ & $\begin{array}{l}\text { Área de } \\
\text { margem e } \\
\text { entorno (ha) }\end{array}$ & $\begin{array}{l}\text { Área total de } \\
\text { intervenção } \\
\text { (ha) }\end{array}$ \\
\hline Trecho 1 & Canal Navegável Tietê & 52,9 & 115,7 & 168,6 \\
\hline Trecho 2 & Canal Navegável Tietê & $1.595,2$ & $1.568,4$ & $3.163,60$ \\
\hline Trecho 3 & Canal Navegável Pinheiros & 6,7 & 3,2 & 9,9 \\
\hline Trecho 4 & Lago Navegável Billings & 134 & 99,1 & 233,1 \\
\hline Trecho 5 & Lago Navegável Taiaçupeba & 190 & 15,1 & 205,1 \\
\hline Trecho 6 & $\begin{array}{l}\text { Cidade Canal Billings - } \\
\text { Taiaçupeba }\end{array}$ & $60.460,00$ & $1.060 .211,8^{*}$ & $1.120 .671,8^{*}$ \\
\hline & TOTAL & $62.438,80$ & $1.062 .013,3$ & $1.124 .452,1$ \\
\hline
\end{tabular}

23

Fonte: SELT (2011b)

O Trecho 2 corresponde à área da APA da Várzea do Rio Tietê e canal com a maior área a ser alagada segundo o projeto proposto. Nos mapas abaixo estão espacializadas as obras do Hidroanel e as áreas a serem alagadas, destacando-se que atualmente não existem os reservatórios do mapa. Destaca-se também que a área em verde escuro corresponde a área da APAVRT.

23* Área que compreende uma série de outras obras de infraestrutura associadas como o bulevar fluvial, parque fluvial, habitação social, equipamentos públicos e áreas de preservação. (SELT, 2011b) 
Figura 19 - Mapa do projeto do Hidroanel do canal navegável do rio Tietê (folha 1)

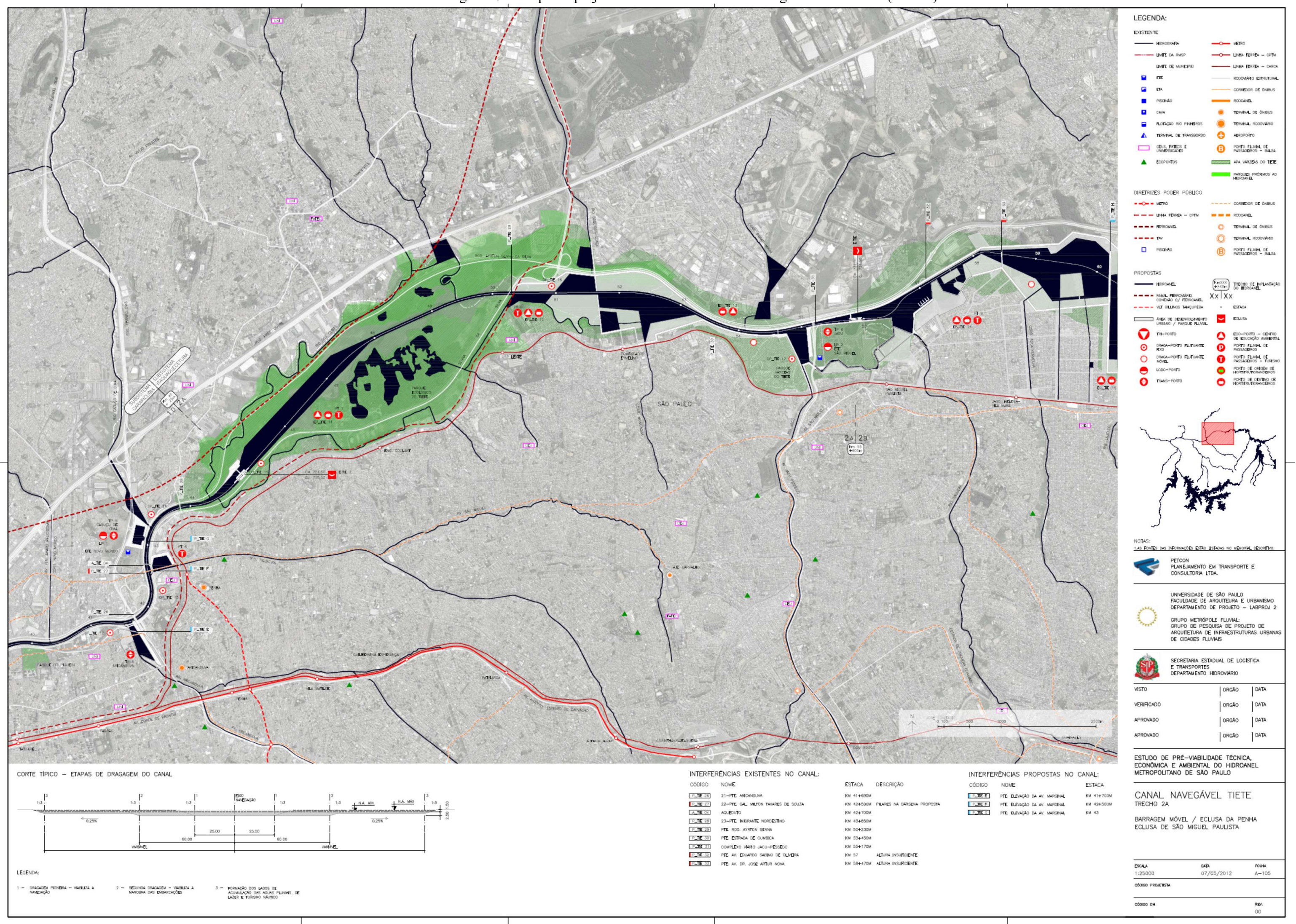

Fonte: SELT (2011) 
Figura 20 - Mapa do projeto do Hidroanel do canal navegável do rio Tietê (folha 2)

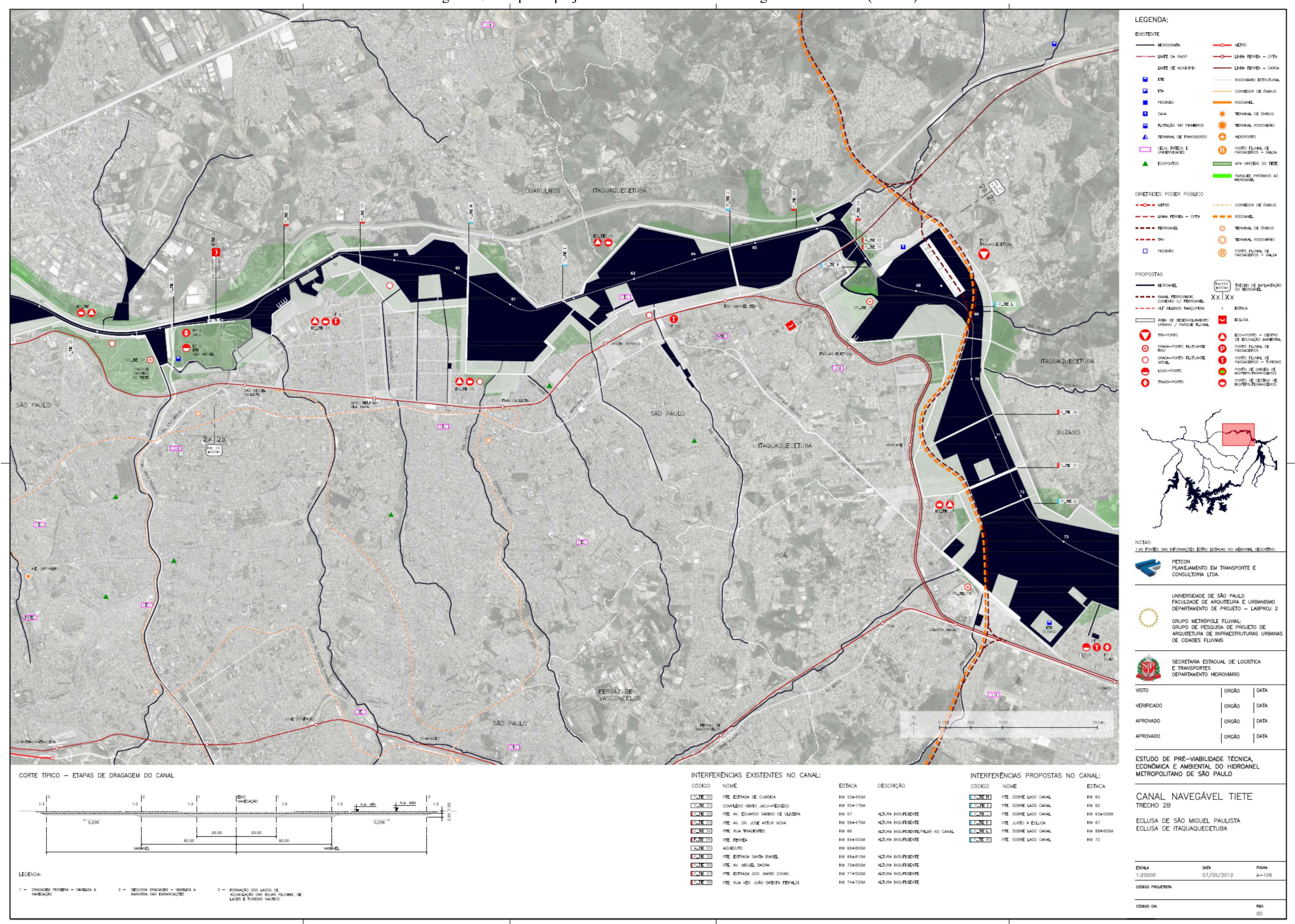

Fonte: SELT (2011) 
Figura 21 - Mapa do projeto do Hidroanel do canal navegável do rio Tietê (folha 3)

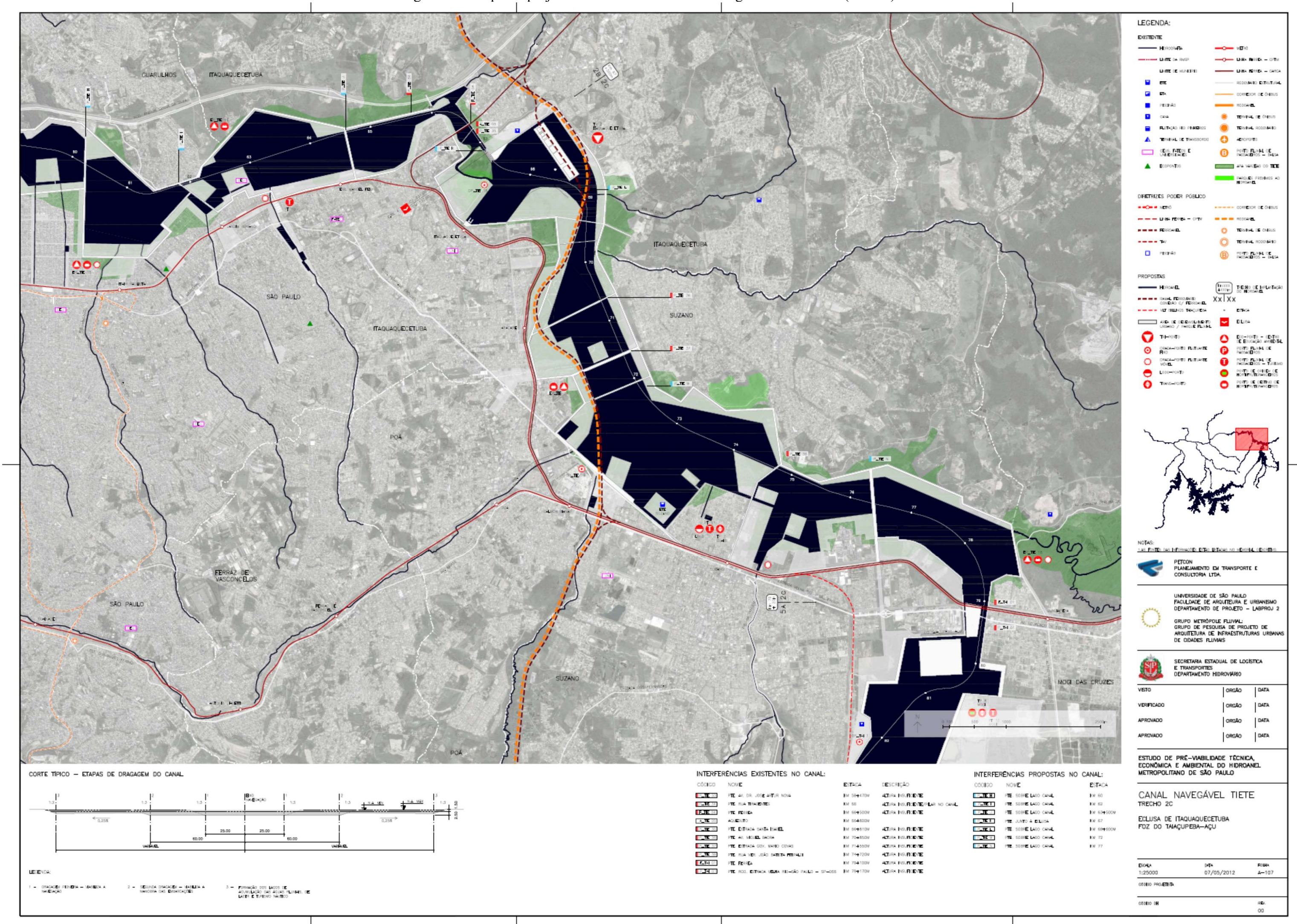

Fonte: SELT (2011) 
No primeiro trecho do projeto (fig. 18), as intervenções são menores na área do Parque Ecológico do Tietê, entretanto são várias as intervenções na área fora do parque. Destaca-se nesse mapa e no seguinte as áreas que serão inundadas para a criação de lagos e a ampliação do canal navegável.

A partir dos mapas, pode-se visualizar a área de inundação, prevista pelo Hidroanel, em azul escuro; na tonalidade verde, no entorno, são as áreas da APA. A área em que há a sobreposição do Hidroanel (trecho 2 do Tietê) com a APA será alagada em 1595,2 ha. Destacadas nos mapas acima, as áreas da APA, em verde, que margeariam o rio Tietê, são sobrepostas pelo azul escuro da área de inundação, sobrando apenas alguns fragmentos no entorno das lagoas do Hidroanel.

Das etapas do projeto foi iniciada somente a primeira eclusa da barragem da penha em 2013, com a previsão inicial de conclusão em 2015 e adiada até 2018 (DH, 2015; CAPELHUCHNIK, 2016; CETENCO, 2017). Foi sinalizado que haveria as obras da segunda eclusa em 2016 e da barragem móvel de São Miguel Paulista para criação do primeiro lago artificial do trecho, no entanto sem previsão de ocorrer (CAPELHUCHNIK, 2016).

Vale destacar que o projeto do Hidroanel tem certa repercussão na agenda, conseguindo um parecer favorável do CADES de São Paulo em 2012 (SVMA, 2012). Ele é considerado estratégico e importante nos relatórios da Frente Parlamentar das Hidrovias (FPH, 2010; 2013), também foi incluído e considerado estratégico pelo Plano de Mobilidade de São Paulo (SÃO PAULO, 2015) e aparece como importante investimento no Plano de Ações da Macrometrópole da EMPLASA e no Plano de Desenvolvimento Urbano Integrado (EMPLASA, 2015; 2017). Contudo, atualmente, não existe uma agenda definida para os estudos de avaliação, licitação e execução das obras do Hidroanel $^{24}$.

${ }^{24}$ Informação obtida ao consultar o Departamento Hidroviário da Secretaria de Logística e Transportes. 


\section{8 - Linha 13 da CPTM}

O projeto de expansão da linha de trem da CPTM até o aeroporto de Guarulhos foi proposto no Plano Integrado de Transportes Urbanos 2020 (PITU 2020) elaborado em 1999 (STM, 1999). Originalmente, no projeto, está previsto integrar os 3 aeroportos (Cumbica, Campo de Marte e Congonhas) da metrópole pela rede ferroviária, além de uma ampliação considerável da rede metroviária da metrópole (STM, 1999; FREDERICO, 2001). No esquema abaixo estão representadas a expansão do transporte sobre trilhos pelo PITU 2020, com destaque as linhas em verde, que correspondem ao projeto de trens para os aeroportos.

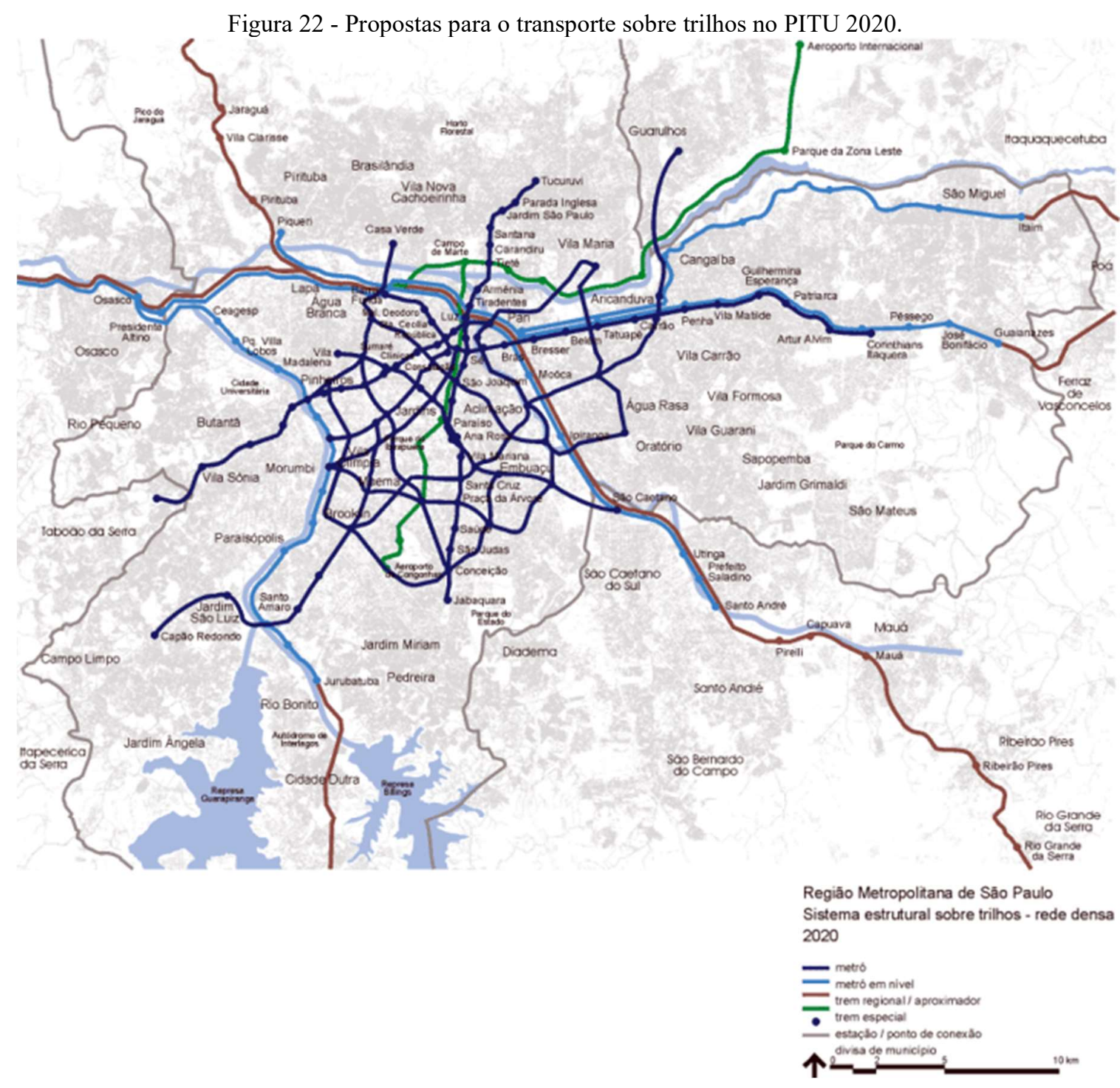

Fonte: STM (1999) 
Pelo plano está definido que seriam $44 \mathrm{~km}$ de linhas de trem especial e com a previsão de ser executado entre 2010 e 2015(STM, 1999; FREDERICO, 2001). Outro fator importante foi a eleição do Brasil como sede da Copa do Mundo de 2014, fator que implicou em uma importância estratégica (TAVARES; MACEDO, 2009).

O desenvolvimento desse projeto foi marcado inicialmente por uma série de falhas nos primeiros EIA-RIMAs (TAVARES; MACEDO, 2009). O primeiro EIA-RIMA foi rejeitado pela SMA por uma série de falhas e lacunas na avaliação ambiental e o segundo EIA-RIMA, apresentado em 2009, foi alvo de uma Ação Civil Pública, paralisando as obras da linha 13 (MPSP, 2009; TAVARES; MACEDO, 2009)

Em 2013, foi aprovado um novo licenciamento para a Linha 13 e o projeto foi alterado, reduzindo a extensão da linha da estação Engenheiro Goulart até a estação CECAP. O projeto tem aproximadamente 12,2 km de linha, da qual 7,9 km será elevada, 5 canteiros de obras e 3 novas subestações de energia para reduzir os impactos na APA (CETESB, 2013). Após aprovação do novo licenciamento, as obras foram iniciadas pouco depois e foram concluídas em 2018.

\section{9 - Ferroanel}

$\mathrm{Na}$ década de 1950, a ideia de um Anel Ferroviário entrou na agenda do governo estadual e o primeiro projeto foi elaborado em 1963 (CORREIO DA MANHÃ, 1970). Em 1970 seria elaborado o estudo de viabilidade técnica do Anel Ferroviário para conseguir financiamento com o Banco Mundial (CORREIO DA MANHÃ, 1970).

O projeto se dividia nos seguintes trechos e municípios:

\footnotetext{
O estudo foi baseado em levantamentos e análises de tráfego regional e estadual e apontou estas cidades para serem servidas pelo Anel: SETOR Sul - São Bernardo do Campo, Santo André, Mauá, Ribeiro Pires (à construir); SETOR LESTE - Rio Grande da Serra, Ribeirão Pires, Suzano (em construção); SETOR NORTE Itaquaquecetuba, Guarulhos (em tráfego); São Paulo, margem do Rio Tietê (a construir); SETOR OESTE - São Paulo, margem do Rio Pinheiros (implantando o terceiro trilho) e Diadema (a construir). (CORREIO DA MANHÃ, 1970, p.5)
}

Esse projeto entrou na agenda a partir da ideia da comissão da Estrada de Ferro Sorocabana de integrar a Estada de Ferro Santos-Jundiaí, E.F. Central do Brasil e a Estrada de Ferro Sorocabana (CORREIO DA MANHÃ, 1970). 
Na notícia do Correio da Manhã (1970), o Anel Ferroviário seria executado até 1985, integrando as linhas existentes. Entretanto, da nova infraestrutura, foi executado somente o ramal que interliga Suzano a Rio Grande da Serra (SELT, 2011b). Atualmente o projeto foi retomado com a denominação de Ferroanel.

O Ferroanel é um projeto que consta tanto no PPA 2008-2011 como no 2016-2019. Sua execução está atrelada ao Rodoanel (PEREIRA, 2012; AE, 2013). O projeto desde 2008 reapareceu na pauta política, mas somente recentemente ganhou mais força, com o acordo definido em 2015, a licitação para as obras em 2016 e um projeto proposto em 2017 (PIMENTEL, 2016, SÃO PAULO, 2016a).

O projeto foi divido em etapas e a primeira parte a ser executada é o trecho norte, o qual o estudo foi começado em 2011 em parceria com a concessionária ferroviária MRS. Em 2017 foi apresentado o Estudo de Impacto Ambiental (EIA) pelo governo estadual (SANTIAGO, 2017). 
Figura 23 - Trajeto do Ferroanel e área de impacto direto e indireto.

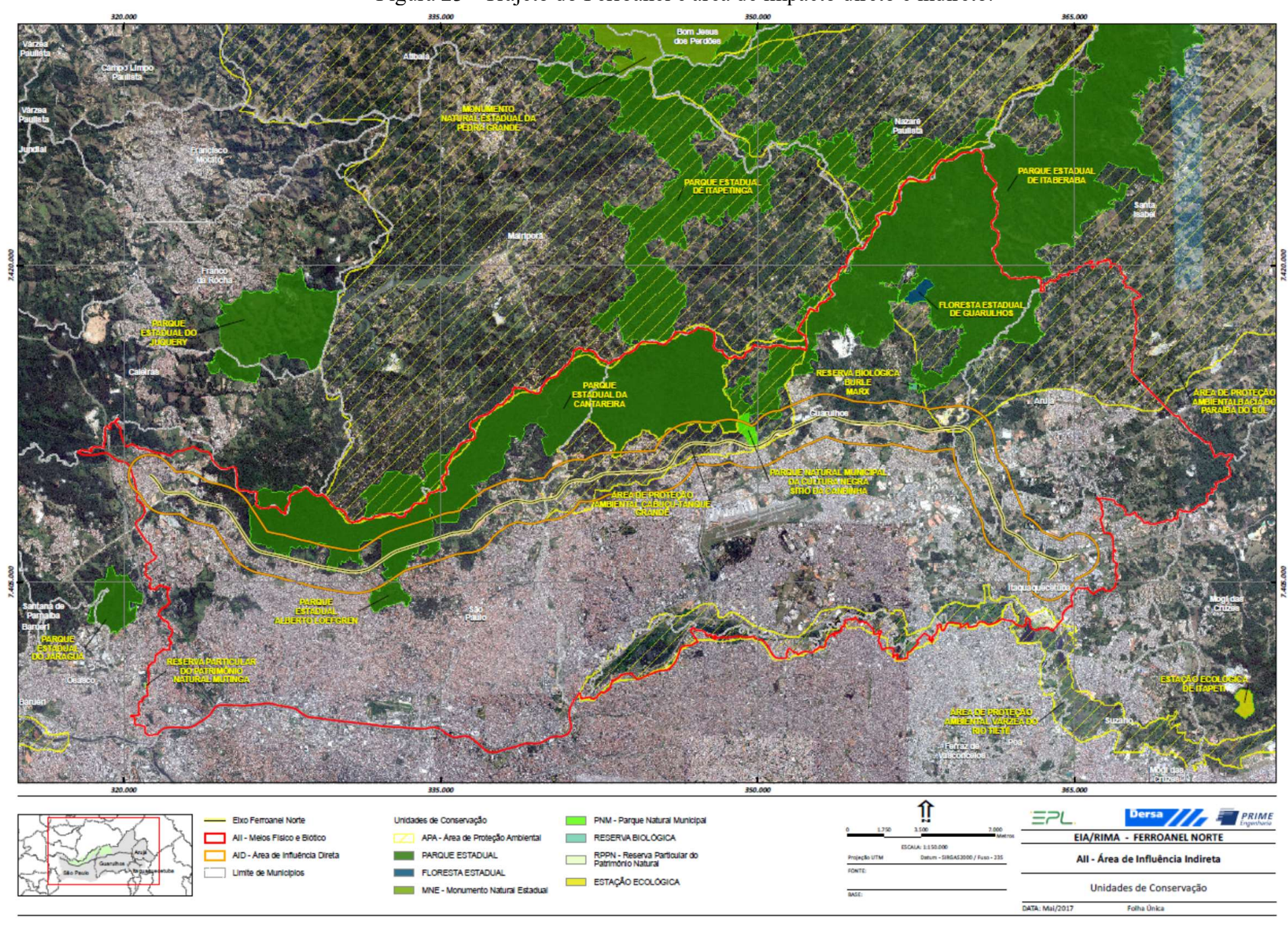

Fonte: EPL, DERSA e PRIME Engenharia (2017) 
No Relatório de Impacto Ambiental (RIMA) e como pode ser observado no mapa o traçado do Ferroanel, trecho norte, não se sobrepõe a área da APA VRT, contudo a APA está inserida na Área de Influência Indireta do empreendimento. No RIMA, está relatado que o Ferroanel Norte terá como área de influência direta a faixa de domínio do Rodoanel, o que implicaria em um menor impacto ambiental (EPL; DERSA; PRIME ENGENHARIA, 2017).

\section{10 - Outros projetos}

Neste tópico, comenta-se brevemente que há outros planos, programas e projetos que interferem ou interfeririam no território da APA da Várzea do Rio Tietê e seriam importantes a serem considerados, mas que não serão aprofundados pela presente pesquisa.

Outros planos e projetos dignos de nota são o Plano de Ação da Macrometrópole PAM, o Trem de Alta Velocidade (TAV), o Plano de Macrodrenagem, Plano Diretor de Esgoto, o Plano Diretor de Aproveitamento de Recursos Hídricos para a Macrometrópole Paulista. Estes planos e projetos têm importantes implicações para o território, por serem subsídios ou respaldarem os planos e projetos analisados pela pesquisa. A única exceção é o TAV, projeto que foi suspenso.

\subsection{1 - Síntese dos Planejamentos}

O modelo proposto por Raffestin $(2012 ; 2015)$ é retomado neste tópico com base no que foi discutido nos capítulos e tópicos anteriores. A partir, então, da caracterização dos projetos e das instituições, é possível estabelecer o seguinte quadro: 
Quadro 8 - Modelo de Raffestin aplicado para o território da APA da Várzea do Rio Tietê

\begin{tabular}{|c|c|c|c|c|}
\hline A & $\mathrm{L}$ & M & $\mathrm{P}$ & $\mathrm{R}$ \\
\hline $\begin{array}{l}\text { Fundação } \\
\text { Florestal }\end{array}$ & Reprodução & $\begin{array}{l}\text { Plano de } \\
\text { Manejo da } \\
\text { APA VRT }\end{array}$ & Conservação ambiental & $\begin{array}{c}\text { Elaboração do Plano de Manejo; } \\
\text { Acompanhamento dos Licenciamentos; }\end{array}$ \\
\hline EMPLASA & Reprodução & PDUI & $\begin{array}{c}\text { Promover as Funções de } \\
\text { Interesse Comum/Orientar o } \\
\text { planejamento metropolitano }\end{array}$ & $\begin{array}{l}\text { Elaboração do PDUI; Estabelecer base } \\
\text { Integrada de dados; }\end{array}$ \\
\hline DERSA & Produção & Rodoanel & $\begin{array}{c}\text { Acelerar o transporte para o } \\
\text { Porto }\end{array}$ & $\begin{array}{c}\text { Divisão do Rodoanel por etapas; Elaboração } \\
\text { dos EIA/RIMAS; Audiências Públicas; } \\
\text { Execução das obras }\end{array}$ \\
\hline $\begin{array}{c}\text { EPL e } \\
\text { DERSA }\end{array}$ & Produção & Ferroanel & $\begin{array}{l}\text { Diversificar modais e } \\
\text { diminuir fluxo de carga nas } \\
\text { rodovias }\end{array}$ & $\begin{array}{l}\text { Acordo entre as esferas Estadual e Nacional; } \\
\text { Projeto do Ferroanel; Consulta Pública; }\end{array}$ \\
\hline $\begin{array}{l}\text { Departamento } \\
\text { Hidroviário } \\
\text { (SELT) }\end{array}$ & Produção & Hidroanel & $\begin{array}{l}\text { Recuperar os rios a partir de } \\
\text { usos relacionados a } \\
\text { transporte }\end{array}$ & $\begin{array}{l}\text { Encomendar o Projeto do Hidroanel; } \\
\text { Construção de Eclusas }\end{array}$ \\
\hline SMA & Reprodução & ZEE & $\begin{array}{l}\text { Desenvolvimento } \\
\text { Sustentável considerando a } \\
\text { capacidade suporte }\end{array}$ & $\begin{array}{l}\text { Seleção de empresa para realizar a análise; } \\
\text { Acompanhamento Técnico CPLA }\end{array}$ \\
\hline СРТМ & Produção & Linha 13 & $\begin{array}{c}\text { Conexão Capital e } \\
\text { Aeroporto Internacional }\end{array}$ & Projeto da Linha; EIA/RIMA; Obras \\
\hline DAEE & Reprodução & PVT & $\begin{array}{l}\text { Conter expansão urbana no } \\
\text { entorno do rio }\end{array}$ & $\begin{array}{c}\text { Financiamento BID; Projeto do parque; } \\
\text { Remoção de Famílias; Encurtamento do } \\
\text { Projeto }\end{array}$ \\
\hline SABESP & Produção & $\begin{array}{l}\text { Projeto Tietê } \\
\text { Fase IV }\end{array}$ & Despoluição do Rio Tietê & $\begin{array}{c}\text { Financiamento do BID, expansão da rede de } \\
\text { coleta e tratamento de esgoto, audiências } \\
\text { públicas }\end{array}$ \\
\hline $\begin{array}{l}\text { Comitê de } \\
\text { Bacia } \\
\text { Hidrográfica }\end{array}$ & Reprodução & $\begin{array}{c}\text { Plano de } \\
\text { Bacia } \\
\text { Hidrográfica }\end{array}$ & $\begin{array}{l}\text { Melhoria e monitoramento } \\
\text { da qualidade de água e } \\
\text { orientar a gestão de recursos } \\
\text { hídricos }\end{array}$ & $\begin{array}{c}\text { Elaboração de cenários e plano de ação até } \\
\text { 2045, oficinas participativas e audiências } \\
\text { públicas. }\end{array}$ \\
\hline
\end{tabular}

Elaborado pelo o autor

A partir desse quadro, suscita-se questionamentos relativos à sobreposição e articulação destes múltiplos objetivos e a compatibilização das diversas ações. Além do aspecto temporal representado no começo do capítulo, agora se confronta as diferentes naturezas dos elementos analisados pela pesquisa. Ressalta-se que, a partir da leitura do 
quadro, observa-se que alguns programas têm objetivos comuns, como a Fundação Florestal, o DAEE e a SMA; ou tem programas análogos como o Hidroanel, o Ferroanel e o Rodoanel. No entanto, mesmo tendo objetivos comuns, existem sobreposições e conflitos relativos às alternativas.

Há também de destaque que todos os projetos, em princípio, têm como justificativa a sustentabilidade. Scatena (2015) verificou que, apesar de conflitantes entre si, o Hidroanel, a APAVRT e o PVT tinham como um dos argumentos promover a sustentabilidade. Da mesma maneira, chama a atenção que, de alguma forma, parte desses planos e projetos partem do pressuposto da sustentabilidade, como o ZEE, o PBHAT, o Projeto Tietê IV, enquanto outros fazem menção à questão ambiental, como o Rodoanel, que teve uma Avaliação Ambiental Estratégica como um fator favorável à sua instalação, a Linha 13 e o PDUI. Nesse sentido, vale destacar que existem múltiplas interpretações de sustentabilidade por cada um desses planos, programas e projetos.

Torna-se necessário, considerando as similaridades e proximidades dos planos e projetos, visualizar a sobreposição dos diferentes territórios e os conflitos que se sobrepõem na APA VRT. Para realizar essa comparação foi feita a análise espacial utilizado o QGIS para sobrepor os diferentes layers, representando os limites da APA, do parque linear do PVT, os traçados dos projetos viários (Rodoanel, Hidroanel, TAV ${ }^{25}$, Linha 13) e as áreas inundadas pelo projeto do Hidroanel.

Os seguintes mapas são as sínteses dessas sobreposições e comparações com o ferramental da análise espacial.

${ }^{25} \mathrm{O}$ Trem de Alta Velocidade (TAV), o projeto foi suspenso por tempo indeterminado em 2013. 
Figura 24 - Mapa síntese das sobreposições planos e projetos na APAVRT no trecho Oeste

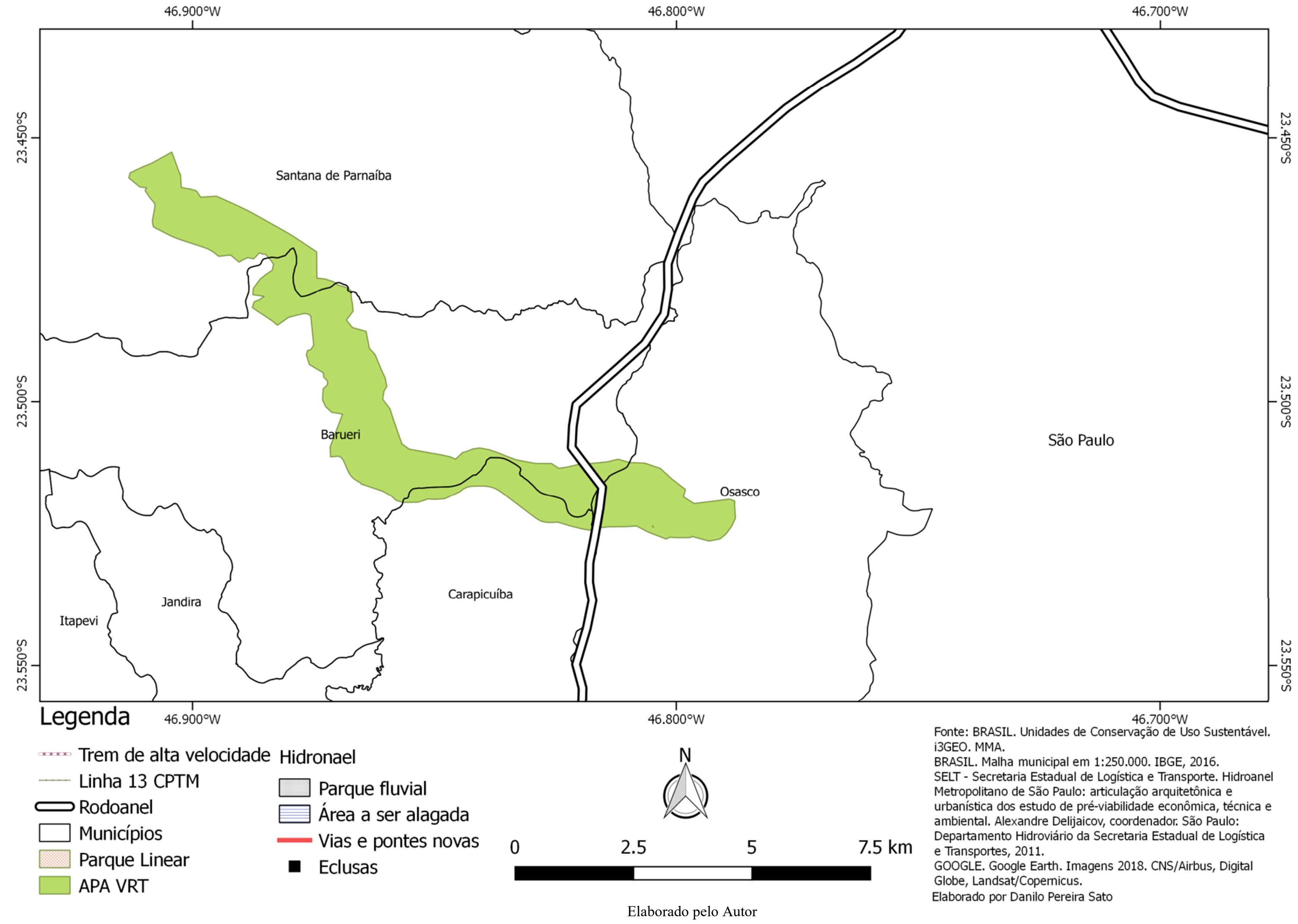


Figura 25 - Mapa síntese das sobreposições planos e projetos na APAVRT no trecho Leste (folha 1)

$46.500^{\circ} \mathrm{W}$

$46.400^{\circ} \mathrm{W}$

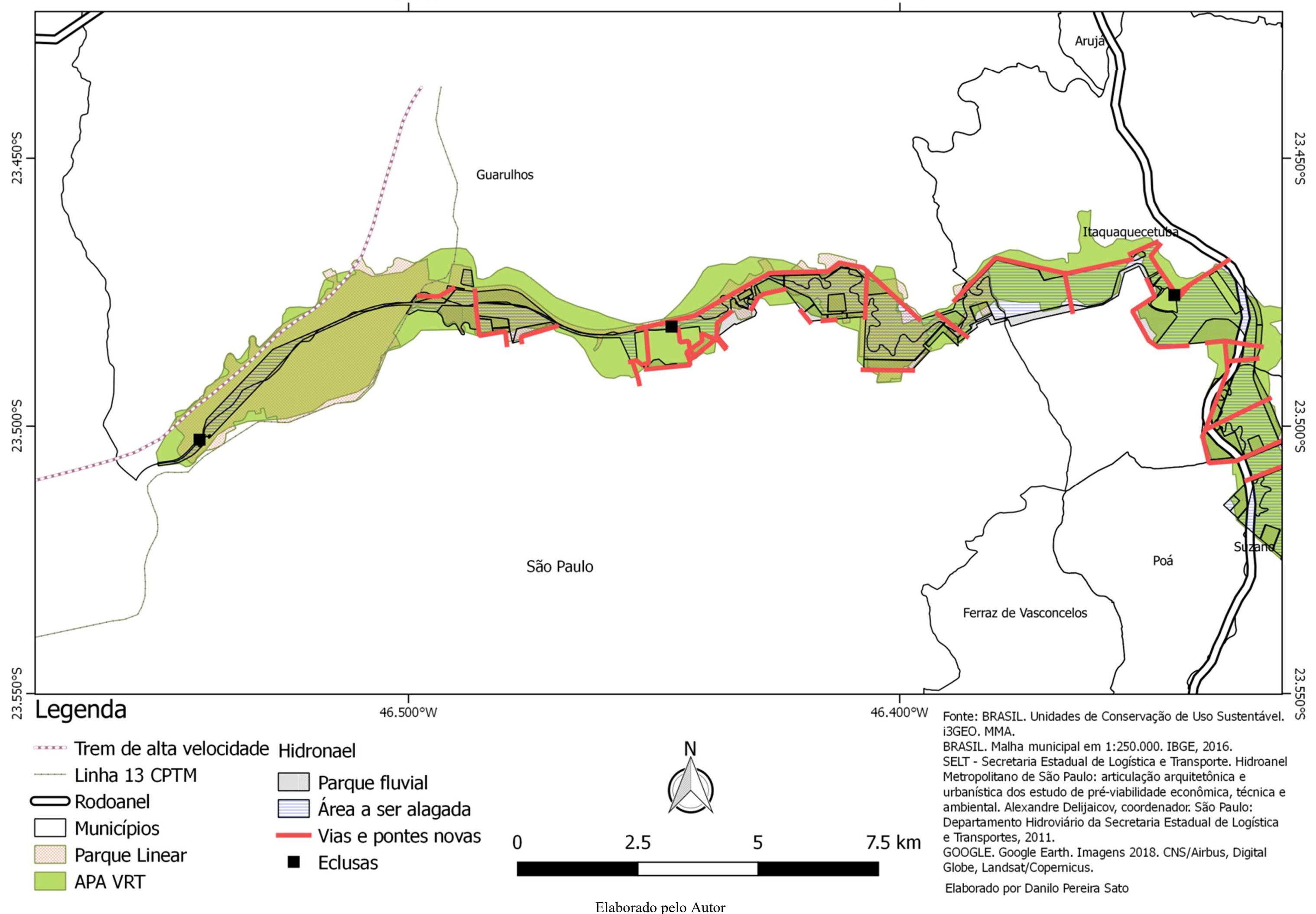


Figura 26 - Mapa síntese das sobreposições planos e projetos na APAVRT no trecho Leste (folha 2)

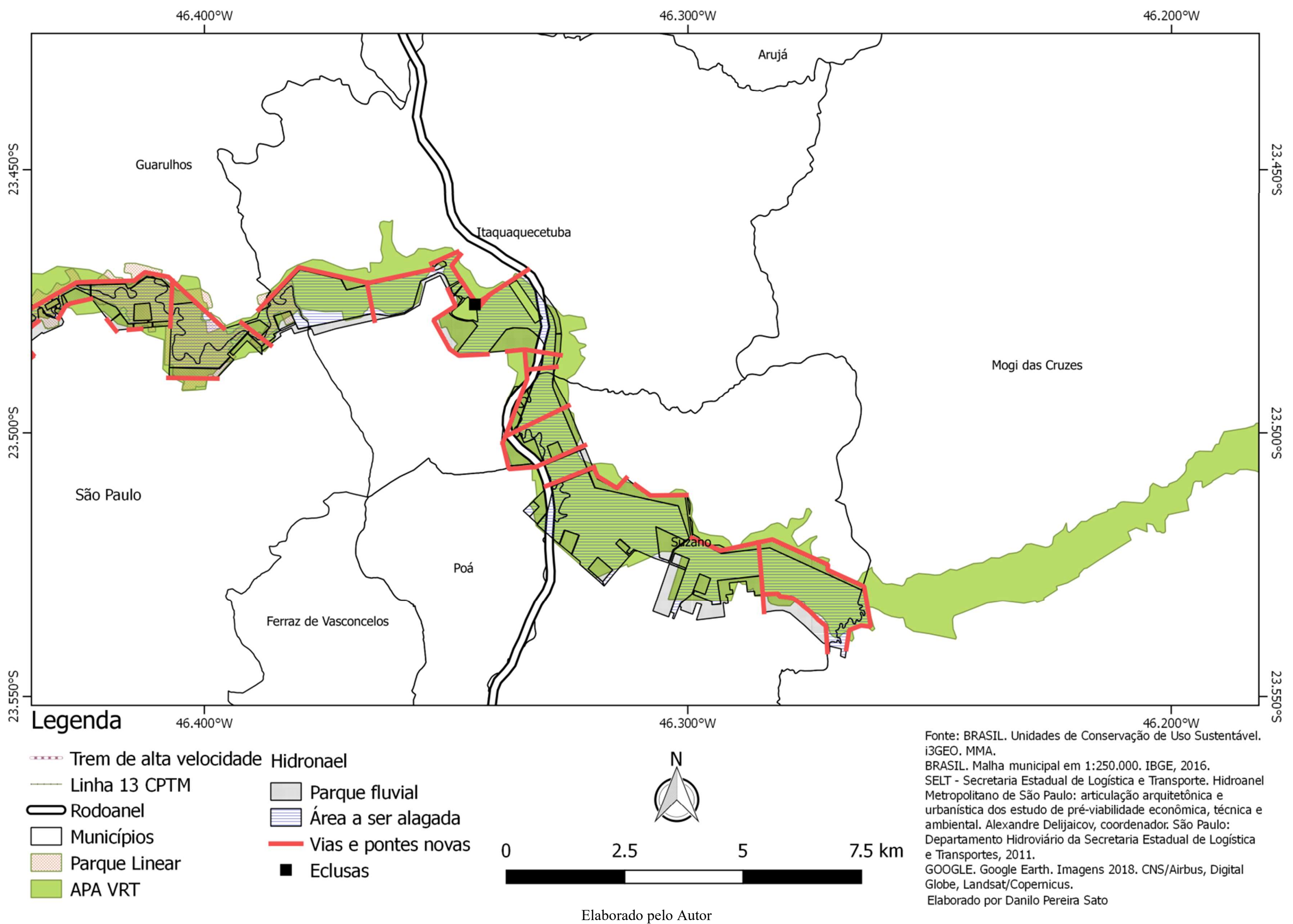


Nos mapas, pode-se visualizar que os projetos se sobrepõem, principalmente, na porção entre São Paulo e Suzano da APA da Várzea do Rio Tietê. Projetos como a Linha 13 da CPTM, o Parque Linear e o Trem de Alta Velocidade estão concentrados na parte da APA entre São Paulo e Guarulhos. O projeto do Hidroanel, por outro lado, tem uma extensão maior de sobreposições e se estende de São Paulo à Suzano.

Com relação ao Hidroanel, é importante observar que, como descrito anteriormente, caso o projeto seja executado, está previsto uma área de intervenção de 3.163,6 ha, dos quais 1.595,2 ha (86\% na área da APA) são áreas a serem alagadas e 1.568 em áreas de margem (45,9\% na área da APA). No projeto está previsto uma série de vias e pontes novas em linhas vermelhas nos mapas.

Nos mapas a seguir foi sobreposto o uso do solo da APA com as áreas propostas de alagamento para o Hidroanel. Essa sobreposição foi feita com o objetivo de visualizar qual a tipologia de uso das áreas impactadas, considerando a importância da parte leste da APA e considerando as várzeas preservadas. 


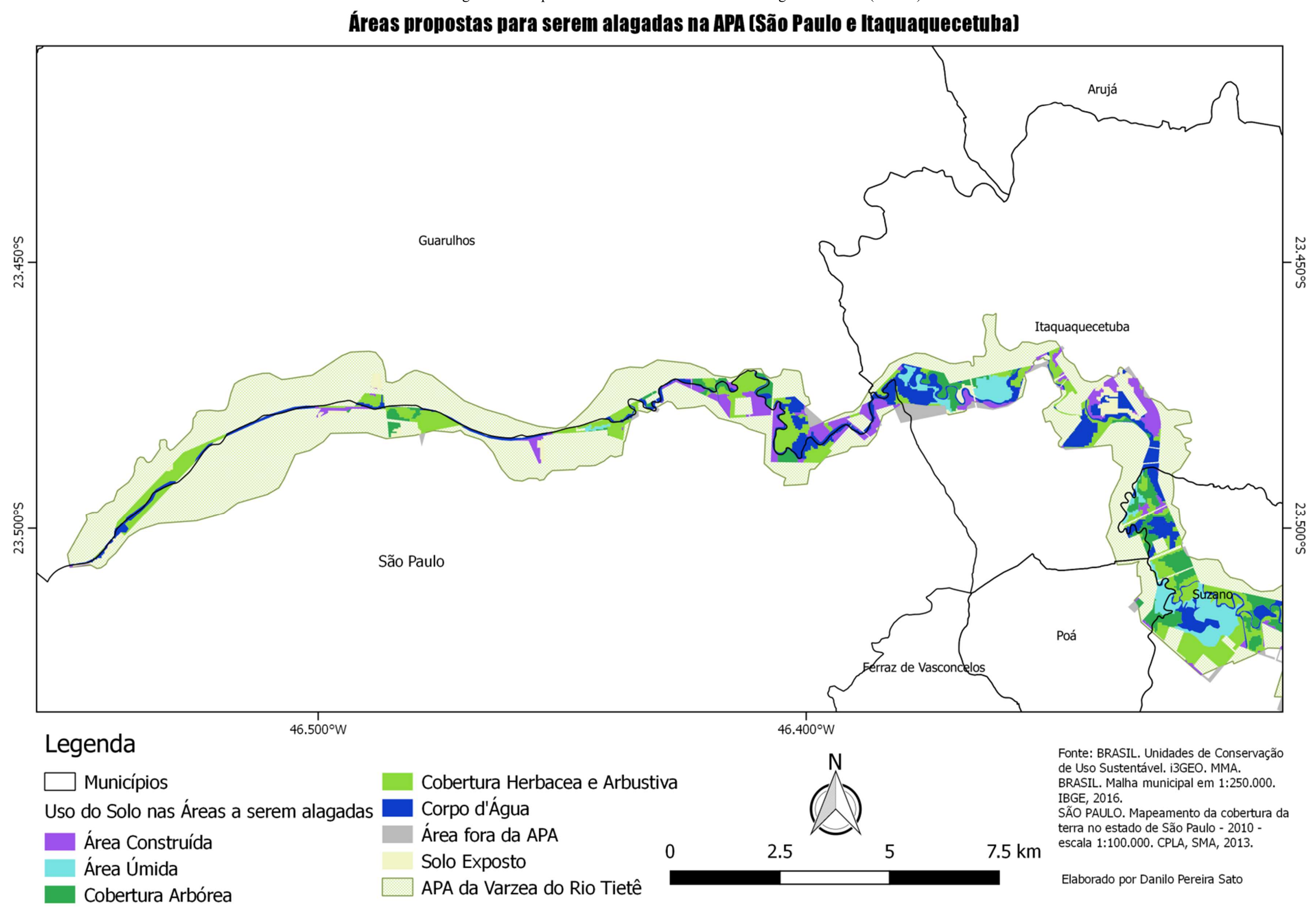

Elaborado pelo autor 


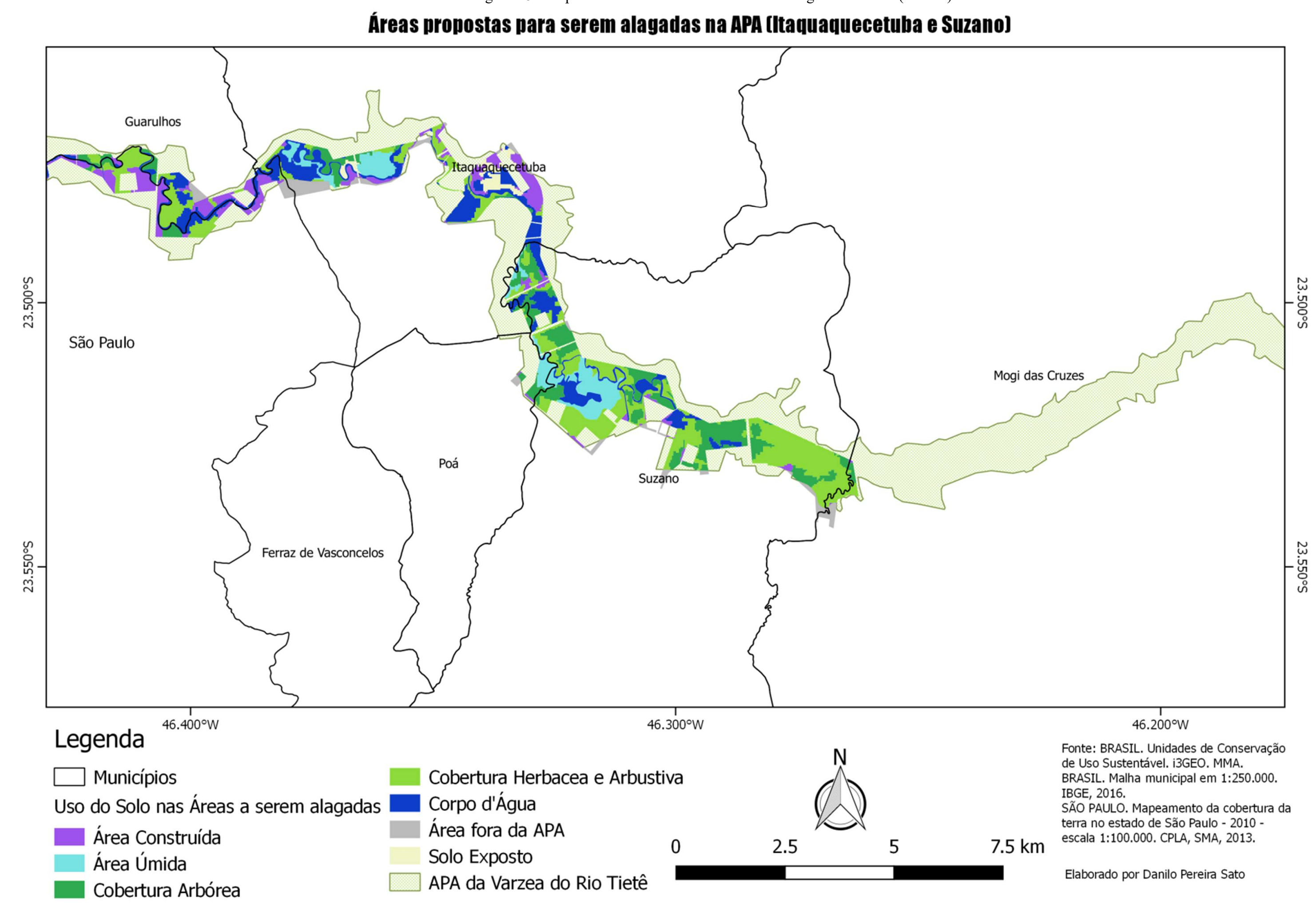

Elaborado pelo autor 
Além dos mapas, foi feita uma síntese a partir do cálculo da área de cada tipo de uso, com o perímetro proposto para as áreas a serem alagadas. Essa operação foi feita a partir do QGIS, com operações de overlay, georreferenciamento dos mapas do Hidroanel, união e cálculo de área. Destaca-se que o cálculo de área é um valor aproximado, pois o layer de Uso do Solo utilizado foi elaborado pela Secretaria de Meio Ambiente, com base em imagens de satélite e, consequentemente, os contornos dos polígonos tem uma precisão menor. Essa imprecisão se deve ao tamanho dos pixels e uma generalização de algumas áreas, distorcendo o perímetro de algumas tipologias.

Tabela 4 - Cálculo do Uso do Solo das Áreas a serem alagadas

\begin{tabular}{|c|c|c|}
\hline Uso do Solo & $\begin{array}{c}\text { Área em } \\
\text { Hectares }\end{array}$ & $\begin{array}{c}\text { Percentual da área } \\
\text { total da APA }\end{array}$ \\
\hline Área Construída & 347.49 & $5 \%$ \\
\hline Área Úmida & 58.893 & $1 \%$ \\
\hline Cobertura Arbórea & 333.877 & $5 \%$ \\
\hline Cobertura Herbácea e & 532.814 & $7 \%$ \\
\hline Arbustiva & 536.618 & $7 \%$ \\
\hline Corpo D'Água & 88.637 & - \\
\hline Solo Exposto & 12.338 & $19 \%$ \\
\hline Fora da APA & 1374.049 & $26 \%$ \\
\hline Área a ser Alagada & 1910.667 & \\
\hline Total &
\end{tabular}

Elaborado pelo autor

Comparando os valores da tabela acima com os valores descritos no projeto do Hidroanel, existe uma diferença de 92,622 ha. Essa diferença se deve às questões expostas anteriormente, sobre a precisão das imagens de satélite. Verifica-se também que aproximadamente 11 ha de áreas a serem alagadas estão fora da APA.

Com base na tabela acima é possível verificar que, considerada a área total das áreas alagadas do projeto na APA (1910 ha) e as porções que já correspondem à corpos d'água (536,6 ha), serão inundadas cerca de 1374 ha.

Na tabela abaixo também foi feito o cálculo de forma semelhante para o Uso do Solo na área de intervenção nas margens. Destaca-se, também, a utilização do layer da Secretaria do Meio Ambiente, mencionado anteriormente, possuir um erro relativo a precisão dos 
polígonos por causa da generalização dos pixels na classificação do solo e em particular com relação aos corpos d'água, como também há áreas que terão o curso do rio alterado.

Tabela 5 - Cálculo do Uso do Solo das Áreas de margem

\begin{tabular}{|c|c|c|}
\hline Uso do Solo & Área em Ha & $\begin{array}{c}\text { Percentual da área } \\
\text { total da APA }\end{array}$ \\
\hline Área Construída & 172.936 & $2 \%$ \\
\hline Área Úmida & 6.91 & $0 \%$ \\
\hline Cobertura Arbórea & 161.695 & $2 \%$ \\
\hline $\begin{array}{c}\text { Cobertura Herbácea e } \\
\text { Arbustiva }\end{array}$ & 284.992 & $4 \%$ \\
\hline Corpo D'Água & 59.207 & $1 \%$ \\
\hline Solo Exposto & 34.096 & $0 \%$ \\
\hline Total & 719.836 & $10 \%$ \\
\hline
\end{tabular}

Elaborado pelo autor.

Comparativamente, as áreas a serem alagadas são mais significativas, pois se sobrepõem em uma área duas vezes e meia maior do que as áreas de margem destinadas ao Parque Fluvial e projetos de desenvolvimento. No entanto, ressalta-se que o projeto do Hidroanel como um todo se sobrepõe em 36\% (26\% de áreas alagadas mais 10\% das áreas de intervenção das margens) do território da APA e estima-se que será alagado 19\% do seu território.

Outro fator importante a ser considerado é o grau de perturbação morfológica das áreas a serem inundadas. Como se observa pelos mapas, de uso do solo das áreas propostas a serem alagadas, é possível deduzir que grande parte das áreas a serem inundadas apresente um baixo grau de perturbação e intervenção humana. No mapa abaixo, utilizando-se das mesmas técnicas dos mapas anteriores, foi sobreposto o grau de perturbação morfológica com as áreas a serem inundadas. 


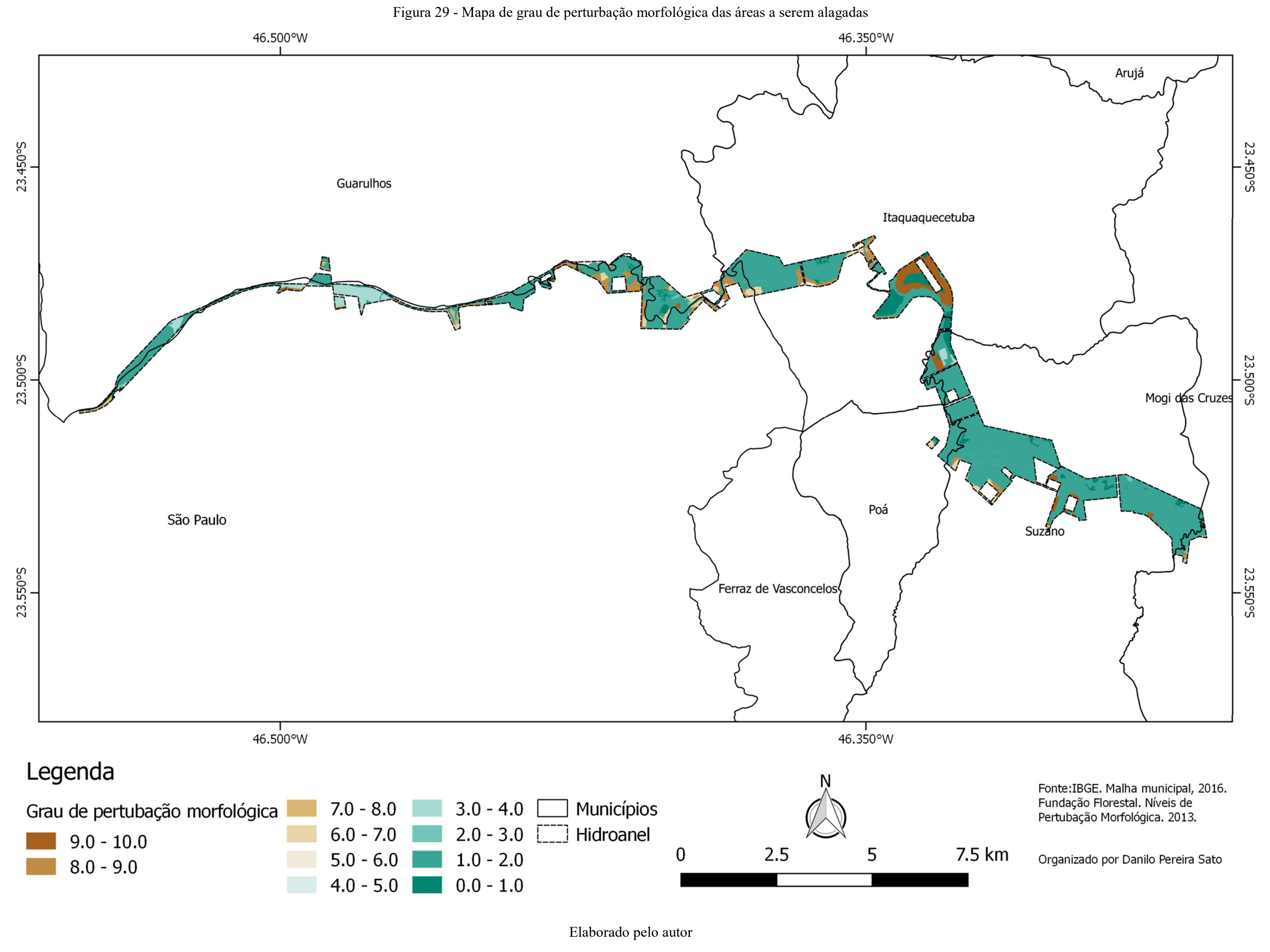


Verificando o mapa, destaca-se o predomínio dos tons mais intensos de verde, o que representa as áreas com baixos graus de perturbação morfológica. Esse aspecto é muito importante, considerando que, pela natureza da planície de inundação e pelos estudos de Rodrigues (2015), são áreas que executariam a função de retenção das águas e atenuando os impactos das inundações.

Considerando o zoneamento vigente, foi feito o overlay e a intersecção, do zoneamento com as áreas dos futuros lagos do Hidroanel, para então fazer as operações de cálculo de área. As zonas que terão uma maior superfície inundadas serão as Zonas de Cinturão Meândrico $\left(10,99 \mathrm{~km}^{2}\right)$, seguidas pelas Zonas de Uso Controlado $\left(4,55 \mathrm{~km}^{2}\right)$ e, por último, a área do Parque Ecológico $\left(2,18 \mathrm{~km}^{2}\right)$. No mapa abaixo foi feita a operação descrita do overlay, a intersecção e o cálculo de área. 
Figura 30 - Zoneamento das áreas a serem alagadas

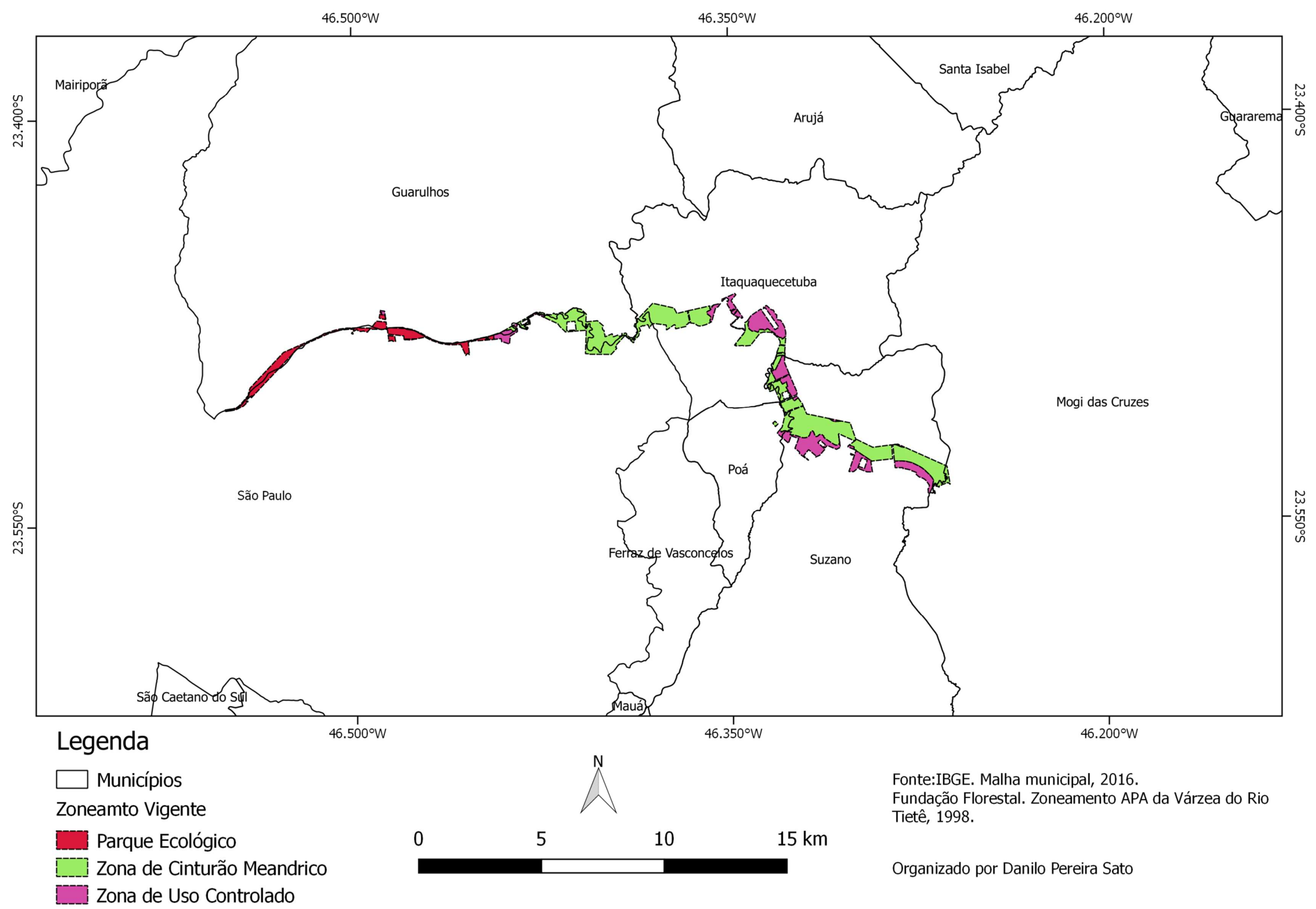

Elaborado pelo autor 
Haja vista a sobreposição desses projetos e com destaque às áreas a serem inundadas pelo Hidroanel, suscita-se questionamentos sobre a possibilidade de compatibilizar e executar esses projetos simultaneamente. Alagar 26\% da APA e, majoritariamente, as áreas com menor perturbação morfológica e com remanescentes naturais, são evidentemente incompatíveis com os interesses da APA. Acrescenta-se que, além das áreas do trecho Oeste já estarem muito impactadas, os diversos projetos previstos até Suzano que implicaram em diversos impactos podem suscitar uma maior pressão urbana. O município de Mogi das Cruzes apresenta uma forte pressão imobiliária sobre as áreas da $\mathrm{APA}^{26}$. Todos esses fatores demonstram uma problemática importante para a manutenção e gestão da APAVRT.

Outra questão que se impõe é qual modelo ou alternativa será optado pelo poder público e a sociedade para o território da APAVRT, considerando as diferentes dinâmicas, impactos e conflitos de cada plano, programa e projeto. Considerando os processos políticos, é possível que a sociedade ou o Estado opte pela supressão da APA ou a alteração de parte do território. No entanto, cabe questionar o ônus dessa supressão ou ocupação, considerando-se os serviços ecossistêmicos oferecidos pela APA, a retenção de águas e atenuação das inundações, os cálculos realizados por Rodrigues (2015) do volume de água que a planície de inundação retém e a quantidade de piscinões que serão necessários para compensar essa função, haja vista a necessidade de piscinões atualmente apontado pelo Plano de Macrodrenagem do DAEE.

Neste sentido, é necessário também analisar, além da articulação institucional, o processo político com as arenas de participação da sociedade em relação a esses projetos, quais são essas arenas e quais setores participam. Para tanto, serão discutidos no próximo capítulo aspectos sobre a governança, a articulação institucional e a participação social.

\footnotetext{
${ }^{26}$ Informação obtida durante Oficina "Indicação de Áreas Verdes Prioritárias Para Conservação e Recuperação na RMSP” realizada pelo Instituto Florestal em parceria com a EMPLASA e a CPLA/SMA.
} 


\section{5- 5 - Governança, Articulação Institucional e Participação Social}

Governança é um termo com definição vaga e começou a ser promovida pelo Banco Mundial nos diversos países em que tinha influência em razão das condicionalidades de seus financiamentos. Capella (2008) levantou os diversos sentidos existentes que variam de acordo com a área do conhecimento (ciência política, relações internacionais, administração pública, etc.) ou mesmo de alinhamento político (direita e esquerda). De modo geral, na literatura é definido como a compreensão de participação e inclusão da sociedade nos processos políticos, assim como as parcerias com entidades privadas, organizações não governamentais, movimentos sociais e propostas de Estado mínimo ou gerencial (CAPELLA, 2008).

Para o meio ambiente, as discussões sobre a necessidade de se incluir a sociedade na política ambiental remonta ao fim da década de 1970 e os anos 1980, com a formação das Organizações Não Governamentais em defesa do Meio Ambiente, com a criação do Sistema de Meio Ambiente (SISNAMA) a partir da Política Nacional de Meio Ambiente etc. (JACOBI, 1999; CUNHA; COELHO, 2003; MOURA, 2016). Essa participação ainda restrita para a sociedade civil e com uma preponderância das representações do poder público (CUNHA; COELHO, 2003).

A participação vai se ampliar também pelas exigências da avaliação de impacto ambiental e a partir da Constituição Federal de 1988, na qual vai se ampliar para várias áreas, como a educação, saúde, política urbana, segurança pública etc. (CUNHA; COELHO, 2003).

A Constituição Federal de 1988, a ampliação da participação social e a governança mudaram o paradigma de elaboração de políticas públicas e na gestão pública. No entanto, esses elementos são incorporados de forma distinta por cada instituição, plano ou projeto. Nos tópicos seguintes será abordado como cada caso analisado nessa dissertação incorpora a participação social e a governança.

\section{1 - APA VRT: Conselho Gestor e CONSEMA}

Primeiramente, destaca-se que, em sequência à criação do CONAMA, no Estado de São Paulo houve a constituição do Conselho Estadual de Meio Ambiente (CONSEMA), que passou a incluir a participação da sociedade e de diversos setores do poder público sobre a 
política ambiental. Destaca-se, inclusive, que a gestão da APAVRT era competência no início (em 1987) do CONSEMA (SCATENA, 2015).

A APAVRT vai ter como exigência para sua estrutura o conselho gestor, que congrega representantes da sociedade civil, do poder público municipal e estadual (COSTA, 2012). O conselho gestor tem como função atender a política ambiental e o conjunto normativo de promover uma gestão participativa da UC a partir do SNUC. O conselho gestor foi criado a partir do decreto estadual 42.837, de 03 de fevereiro de 1998, de caráter consultivo, e tem como objetivos gerenciar, propor articulações e realizar relatórios sobre a situação da APA.

Em 2003, com base no SNUC, o governo estadual lançou o decreto estadual n $n^{\circ} 48.149$, de 9 de outubro de 2003, o qual cria e estipula o funcionamento dos conselhos gestores de todas as APAs estaduais. Acrescentam-se as funções definidas no decreto anterior, de promover a participação e aprovar o plano de manejo da APA, a integração com outras unidades protegidas e acompanhar a aplicação das compensações ambientais.

O conselho possui uma representação bipartite, com 24 vagas para o poder público (metade para representação estadual e a outra municipal) e 24 vagas da sociedade civil (COSTA, 2012). Costa (2012) analisou o conselho a partir da visão da psicologia política no biênio 2010-2012 e destaca, primeiramente, um desequilíbrio na representação do poder público em que o estado possui 12 representantes enquanto cada município conta com 1 representante (totalizando 12 representantes) o que permitiria uma atuação mais coesa entre os representantes estaduais frente aos representantes municipais. Outro fator crítico observado pelo autor é a representação da sociedade civil, na qual foram eleitos representantes de 5 dos 12 municípios (São Paulo, Mogi das Cruzes, Osasco, Suzano, Guarulhos e 1 representante de São José dos Campos (município que não faz parte da APA).

Nas atas do conselho estão visíveis que, nos dois biênios seguintes, esse problema da representação persistiria com uma diminuição dos representantes da sociedade civil de outros municípios. No biênio 2012-2014 os municípios representados eram 4 e no biênio seguinte somente 3 municípios possuíam representantes da sociedade civil. Em todos esses períodos, a maioria dos representantes era de São Paulo, seguido pelos municípios de Mogi das Cruzes e Guarulhos. 
Tabela 6 - Representantes da sociedade civil por município e biênio.

\begin{tabular}{|c|c|c|c|c|c|c|c|c|c|c|c|c|c|}
\hline \multirow{2}{*}{ Município } & \multicolumn{3}{|c|}{ São Paulo } & \multicolumn{3}{|c|}{ Guarulhos } & \multicolumn{2}{c|}{ Mogi das Cruzes } & Osasco & $\begin{array}{c}\text { Suza } \\
\text { no }\end{array}$ & $\begin{array}{c}\text { São José } \\
\text { dos } \\
\text { Campos }\end{array}$ & $\begin{array}{c}\text { Santana } \\
\text { Parnaíba }\end{array}$ \\
\hline Ano & $\begin{array}{c}2010 \\
-\end{array}$ & 2012 & 2014 & -2010 & 2012 & 2014 & 2010 & 2012 & 2014 \\
- & - & - & - & - & - & $2010-$ & $2010-$ & $2010-$ & $2012-$ \\
2012 & 2014 & 2016 & 2012 & 2014 & 2016 & 2012 & 2014 & 2016 & 2012 & 2012 & 2012 & 2014 \\
\hline $\begin{array}{c}\text { Número de } \\
\text { Representant } \\
\text { es }\end{array}$ & 15 & 16 & 14 & 2 & 3 & 4 & 3 & 4 & 6 & 2 & 1 & 1 & 1 \\
\hline
\end{tabular}

Elaborado pelo Autor. Fonte: Atas do Conselho Gestor.

Na tabela acima é visível a grande quantidade de representantes oriundos de São Paulo (variando de 58\% à 66\%), seguidos dos municípios de Mogi das Cruzes e Guarulhos, com uma quantidade tímida de representantes. Destaca-se que, dos demais municípios, será somente uma entidade da sociedade civil e com a atuação restrita a um biênio. Apesar de constar na tabela dois representantes oriundos de Osasco, esses representantes são da mesma instituição, ocupando a posição de titular e suplente no conselho.

Algumas organizações se mantiveram constantes durante os 3 biênios, como a CIESP, a Associação Brasileira de Engenharia Sanitária e Ambiental, o Sindicato Rural de Mogi das Cruzes, a Ação Cultural Afro Leste Organizada, o Instituto Alana, a Associação Paulista de Consultores em Meio Ambiente e representantes da USP (em um primeiro momento da EACH e posteriormente da FFLCH). A CIESP se destaca, inclusive, por aumentar sua representação nos assentos do conselho de um representante para três, substituindo os representantes da FIESP.

No entanto, em 2016, as reuniões foram suspensas e os conselheiros deixaram de acompanhar o processo de avaliação do Plano de Manejo no CONSEMA. Outro fator crucial foi a mudança da composição do conselho mencionado no tópico 3.1, resultando em um processo no Ministério Público.

O fenômeno de alteração da inativação do conselho e alteração da composição do CONSEMA não é um fenômeno isolado. Durante o desenvolvimento da pesquisa, pôde-se verificar alterações na composição de conselhos, redução do espaço de participação, revisão de decisões coletivas etc. Contudo, como esse não é o foco da presente dissertação, não serão detalhados esses outros casos de alteração. 
Além do conselho gestor da APA ser um espaço de governança da APA da Várzea do Rio Tietê e o CONSEMA outra esfera de participação, há também outras instituições importantes, com suas respectivas arenas de participação que atuam no território da APA. Nos próximos tópicos são discutidas quais são as instituições, seus respectivos planos, programas e projetos e as arenas participativas de cada uma.

\section{2 - Articulação institucional do PVT}

A estrutura do projeto compreendia a participação do DAEE, das secretarias relacionadas a recursos hídricos e a habitação, o Banco Interamericano de Desenvolvimento (BID), as prefeituras de São Paulo e Guarulhos, do Comitê da Bacia Alto Tietê e o Colegiado Gestor da APA do Tietê (HOLTZ, 2015). No esquema abaixo está estruturada a organização e administração do programa.

Figura 31 - Estrutura da governança do PVT

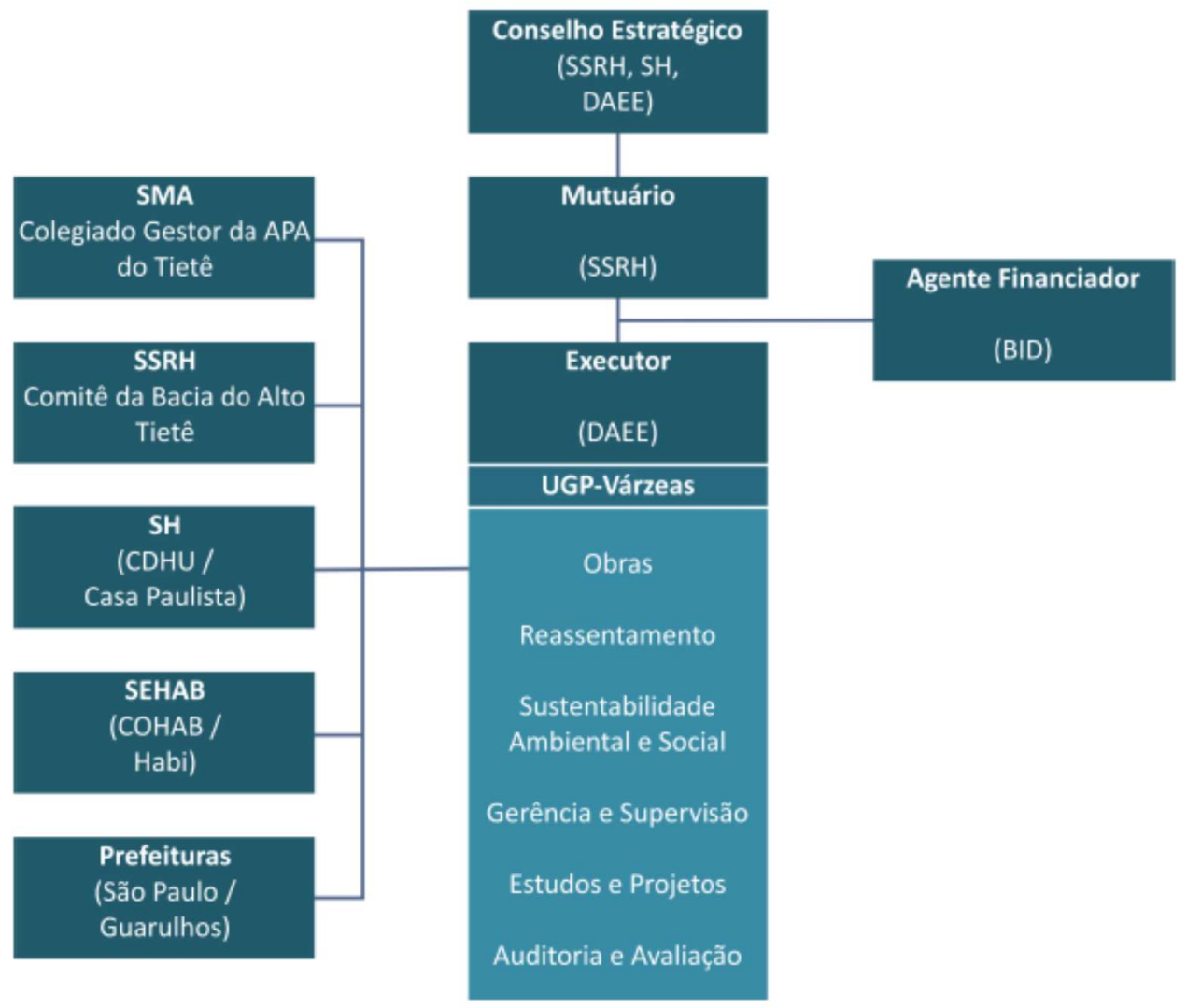

Fonte: Holtz (2015). 
No entanto, essa inclusão não siginifica uma efetiva sinergia, como pode ser verificado na pesquisa de Scatena (2015). Ao entrevistar a gestora da APA, Scatena teve as seguintes considerações:

\footnotetext{
Não é pelo fato de que as instituições tenham assento e enviem representantes para serem conselheiros, que a ela estão de fato criando um canal de articulação, seja para pleito, seja para acolhimento das decisões. $O$ fato de ter um representante de uma prefeitura ou setorial do Estado não faz com que os as ações da prefeitura e do Estado na região sejam alinhadas com os propósitos e regras da APA-VRT, pactuadas no Conselho (LEME ${ }^{27}$ S, 2015, p. 187).
}

Nesse sentido, é interessante observar esse problema, mencionado por Holtz (2015), pois, da mesma maneira, no relatório do projeto do parque Linear existe a reclamação de que mesmo havendo a participação do Conselho Gestor, isso não implicou em uma maior sinergia ou a redução de conflitos.

\section{3 - Plano de Desenvolvimento Urbano Integrado (PDUI)}

A Região Metropolitana de São Paulo (RMSP) foi criada formalmente a partir da Constituição Federal de 1967, mesmo que esse caráter já tinha sido demonstrado antes pelo trabalho de Estrutura Urbana do Aglomerado Paulista (MOTTA; MIRANDA, 2013). Com a criação, seria definido um Conselho da Metrópole, apesar da ação estar centralizada na EMPLASA, que ainda seria criada.

O PDUI conta com o Conselho de Desenvolvimento da RMSP, criado pela LC 1139/2011, formado somente por representantes dos municípios da RMSP. A sociedade civil participa somente do Conselho Consultivo.

A elaboração do PDUI possui o acompanhamento do Comitê Executivo e da Comissão Técnica. O Comitê Executivo é deliberativo e possui atribuição de coordenadar e articular o Estado e a Sociedade Civil e acompanhar a elaboração do PDUI, com representação tripartite

\footnotetext{
${ }^{27}$ LEMES, Fernanda. Fernanda Lemes - Gestora da APA-VRT de 2008 a 2014: Entrevistas [22/10/2015 29/10/2015]. Entrevistador: Gil K. Scatena: São Paulo, 2015. Sonoro. Entrevista concedia a Pesquisa de Mestrado de Gil Scatena “Áreas de Proteção Ambiental e os desafios da gestão territorial para a sustentabilidade: o caso da APA da Várzea do Rio Tietê.
} 
(Estado, Municípios e Sociedade Civil). A Comissão Técnica, com a função de acompanhamento técnico da elaboração do PDUI também é constituída pela mesma representação tripartite que o Comitê Executivo. No documento de orientação sobre o Comitê e da Comissão a sociedade civil, ela deve ser constituída por representantes de movimentos populares (movimentos, associações comunitárias ou de moradores); entidades trabalhistas (sindicatos e confederações); entidades empresariais (entidades e cooperativas); entidades profissionais, acadêmicas, de pesquisa e conselhos profissionais e ONGs (PDUI, 2017).

Pelos critérios definidos a participação social tem um caráter bem heterogêneo, considerando desde movimentos de moradia popular até entidades empresariais. Para analisar, então, quais grupos da sociedade civil estão participando e definindo o PDUI, foi verificado quais setores estavam representados. $\mathrm{Na}$ tabela abaixo são verificados quais setores estão representados no Comitê e na Comissão, separando as diferentes representações que compõe o grupo da sociedade civil.

Tabela 7 - Distribuição dos representantes por setor.

\begin{tabular}{|c|c|c|c|c|}
\hline & \multicolumn{2}{|c|}{ Comitê Executivo } & \multicolumn{2}{|c|}{ Comissão Técnica } \\
\hline & Quantidade & Percentual & Quantidade & Percentual \\
\hline $\begin{array}{c}\text { Associação Profissional e } \\
\text { Sindicatos }\end{array}$ & 11 & $18.6 \%$ & 9 & $10.5 \%$ \\
\hline $\begin{array}{c}\text { Associações Empresariais e } \\
\text { Empresas }\end{array}$ & 4 & $6.8 \%$ & 5 & $5.8 \%$ \\
\hline Consórcio Intermunicipal & 13 & $22.0 \%$ & 9 & $10.5 \%$ \\
\hline Gov. Estadual & 8 & $13.6 \%$ & 6 & $7.0 \%$ \\
\hline Gov. Municipal & 14 & $23.7 \%$ & 38 & $44.2 \%$ \\
\hline Mov. Social & 2 & $3.4 \%$ & 15 & $17.4 \%$ \\
\hline Mov. Ambiental & 3 & $5.1 \%$ & 0 & $0.0 \%$ \\
\hline Associação de Bairro & 0 & $0.0 \%$ & 2 & $2.3 \%$ \\
\hline Cooperativa & 0 & $0.0 \%$ & 2 & $2.3 \%$ \\
\hline Universidade & 4 & $6.8 \%$ & 0 & $0 \%$ \\
\hline Total & 59 & $100 \%$ & 86 & $100 \%$ \\
\hline
\end{tabular}

Elaborado pelo Autor Fonte: PDUI (2018) 
Analisando os grupos representados, é notável que algumas representações fazem parte somente do Comitê ou da Comissão. No caso de grupos ambientais, estes estão exclusivamente no Comitê Executivo, não participando da Comissão Técnica, enquanto as cooperativas e as associações de bairro são justamente o oposto. Outro fator que se destaca são as associações profissionais e os movimentos sociais. As associações profissionais tem a maior participação (da sociedade civil) no Comitê Executivo e em segundo na Comissão Técnica. Enquanto os Movimentos Sociais são o maior grupo da sociedade civil na Comissão Técnica, mas é um dos menores grupos no Comitê Executivo.

Destaca-se também que foram feitas oficinas, coordenada pelo IF, a Reserva da Biosfera, a EMPLASA e a CPLA para dar subsídios ao PDUI a partir das metodologias do ZEE. Foram acompanhadas durante a pesquisa as oficinas "Indicação de Áreas Verdes Prioritárias Para Conservação e Recuperação na RMSP" e a "Indentificação de Serviços Ecossistêmicos Metropolitanos", ocorridas em junho de 2018, com a intenção de identificar os serviços ambientais e estruturar melhor a delimitação das áreas a serem protegidas, as retrições e as potencialidades. Ressalta-se que nessas oficinas houve também uma preponderância de representantes dos órgãos públicos em detrimento de representantes da sociedade civil.

\section{4 - Oficinas participativas do Plano de Bacia Hidrográfico do Alto Tietê}

Para a conclusão do PBHAT, foram iniciadas uma série de oficinas participativas com representantes do poder público e da sociedade civil. Essas oficinas têm como objetivos acompanhar e coletar contribuições dos participantes, com relação ao plano que está sendo elaborado, além de conferir legitimidade.

As oficinas se dividiram nos seguintes temas:

1 - Socioeconomia e Uso e ocupação do solo

2 - Qualidade das águas, esgotamento sanitário e resíduos sólidos

3 - Balanço Hídrico e mudanças climáticas

4 - Demandas versus disponibilidade

5 - Gestão dos Recursos Hídricos

6 - Apresentção do PBHAT. 
Foram obtidas as listas de presença das 6 oficinas, com o Comitê de Bacia Hidrográfica, e os representantes de acordo com as instituições para verificar quais setores estavam mais representados nas duas tabelas abaixo.

Tabela 8 - Participantes das $1^{\mathrm{a}}, 2^{\mathrm{a}}$ e $3^{\mathrm{a}}$ oficinas.

\begin{tabular}{|c|c|c|c|c|c|c|}
\hline \multirow[t]{3}{*}{ Setor } & \multicolumn{6}{|c|}{ Reunião } \\
\hline & \multicolumn{2}{|c|}{ Primeira } & \multicolumn{2}{|c|}{ Segunda } & \multicolumn{2}{|c|}{ Terceira } \\
\hline & Quantidade & Percentual & Quantidade & Percentual & Quantidade & Percentual \\
\hline Poder público & 40 & $69 \%$ & 38 & $78 \%$ & 24 & $57 \%$ \\
\hline $\begin{array}{l}\text { Universidades e } \\
\text { Institutos de Pesquisa }\end{array}$ & 6 & $10 \%$ & 4 & $8 \%$ & 8 & $19 \%$ \\
\hline ONGs e Coletivos & 2 & $3 \%$ & 1 & $2 \%$ & 2 & $5 \%$ \\
\hline $\begin{array}{l}\text { Associação } \\
\text { Profissional }\end{array}$ & 2 & $3 \%$ & 1 & $2 \%$ & 5 & $12 \%$ \\
\hline Setor Empresarial & 3 & $5 \%$ & 2 & $4 \%$ & 1 & $2 \%$ \\
\hline Comitê de Bacia & 5 & $9 \%$ & 3 & $6 \%$ & 2 & $5 \%$ \\
\hline
\end{tabular}

Tabela 9 - Participantes das $4^{\mathrm{a}}, 5^{\mathrm{a}}$ e $6^{\mathrm{a}}$ oficinas.

\begin{tabular}{|c|c|c|c|c|c|c|}
\hline \multirow[t]{3}{*}{ Setor } & \multicolumn{6}{|c|}{ Reunião } \\
\hline & \multicolumn{2}{|c|}{ Quarta } & \multicolumn{2}{|c|}{ Quinta } & \multicolumn{2}{|c|}{ Sexta } \\
\hline & Quantidade & Percentual & Quantidade & Percentual & Quantidade & Percentual \\
\hline Poder público & 27 & $55 \%$ & 33 & $70 \%$ & 33 & $56 \%$ \\
\hline $\begin{array}{l}\text { Universidades e } \\
\text { Institutos de } \\
\text { Pesquisa }\end{array}$ & 10 & $20 \%$ & 4 & $9 \%$ & 5 & $8 \%$ \\
\hline ONGs e Coletivos & 3 & $6 \%$ & 2 & $4 \%$ & 5 & $8 \%$ \\
\hline $\begin{array}{l}\text { Associação } \\
\text { Profissional }\end{array}$ & 5 & $10 \%$ & 2 & $4 \%$ & 4 & $7 \%$ \\
\hline Setor Empresarial & 2 & $4 \%$ & 4 & $9 \%$ & 10 & $17 \%$ \\
\hline Comitê de Bacia & 2 & $4 \%$ & 2 & $4 \%$ & 2 & $3 \%$ \\
\hline
\end{tabular}

Destaca-se, primeiramente, a presença do poder público (mais de $50 \%$ em todas as oficinas), seguida da participação de professores e estudantes vinculados a universidades e pesquisadores de institutos de pesquisa. Vale notar que a representação da sociedade civil é baixa considerando os diferentes grupos identificados. As ONGs e Coletivos apresentavam 
uma agenda voltada para questões ambientais de modo geral, as associações profissionais eram aquelas ligadas à SABESP e no setor empresearial a representação se concentrava na CIESP e na FIESP (com exceção da última oficina). Na última oficina teve um aumento considerável da representação do setor produtivo, com diversos sindicatos relativos a atividades rurais, minerária e de extração de areia.

Ressalta-se que o processo de participação do PBHAT ainda não está concluido e estão previstas realizações de audiências públicas com a sociedae em geral. A primeira audiência pública foi no dia 12 de abril de 2018, na qual se destacou a presença do MPSP para acompanhar e avaliar a participação e legitimidade do processo sendo realizado.

\section{5 - Audiências Públicas Projeto Tietê IV}

Para atender as exigências do BID, a SABESP, em conjunto com os consultores contratados, estão conduzindos audiências públicas com a comunidade local impactada pelo projeto Tietê IV. Essas audiências são imprescindíveis e condicionam o empréstimo do BID para com a SABESP. Durante a audiência de Itapevi, no dia 16 de abril, houve um número insuficiente de participantes, o que invalidou a audiência ecausou preocupação dos organizadores, porque, caso o BID considere que a participação foi insuficiente, o financiamento é suspenso.

O plano de participação comunitária define a participação como aspecto essencial, haja vista as diretrizes do BID (SABESP, 2018b). No documento está definido os formatos da participação, a estrutura das audiências e o convite ativo de algumas organizações consideradas relevantes para a participação, como ONGs (SOS Mata Atlântica), instituições governamentais (DAEE) e representates do poder público local (SABESP, 2018b). As audiências estão sendo anunciadas publicamente e abertos à população em geral.

Vale destacar que o representante da SABESP, na audiência pública de Itapevi, comentou da dificuldade de resolver os problemas de poluição, pois outras instituições teriam a competência para atuarem nos diferentes problemas como a fiscalização, multa e controle. Da mesma forma que há esse problema com o pessoal do Comitê de Bacia Hidrográfica e a sua preocupação com relação à capacidade de execução do plano e a necessidade de se articular com outras instituições. De forma generalizada, é visível os entraves e os problemas 
com relação à articulação, governança e fragmentação das diversas instituições que expressam ter dificuldade em se articular.

\section{6 - Articulação institucional e participação no ZEE}

A coordenação, acompanhamento da elaboração, articulação com outras instituições entre outras funções do Zoneamento Ecológico-Econômico (ZEE) é feita pelo Grupo de Trabalho do Sistema Ambiental Paulista do ZEE (GT-SPA/ZEE), grupo composto por 80 dirigentes técnicos do Sistema Ambiental e 30 técnicos da Coordenadoria de Planejamento Ambiental (CPLA) (SMA, 2018b).

A elaboração do ZEE ainda se divide em diversos GTs temáticos para a elaboração do diagnóstico e das propostas, para depois serem submetidas a avaliação do CONSEMA e da Comissão Técnica Estadual do ZEE (SMA, 2018b). Há ainda os Fóruns Consultivos Regionais promovendo discussões sobre o ZEE e as Mesas de Diálogo com as universidades, o setor produtivo e a sociedade civil organizada (SMA, 2018b).

No balanço apresentado no CONSEMA foi apresentado alguns resultados referentes ao diagnóstico participativo que está sendo realizado por bacia hidrográfica. No caso foram apresentadas as oficinas de Tatuí e de Presidente Prudente nas quais em ambas havia uma preponderância do poder público com $82 \%$ e $49 \%$ respectivamente, enquanto a sociedade civil organizada era de 7\% em Tatuí e 13\% em Presidente Prudente (SMA, 2018b).

\section{7 - Síntetizando os Espaços de Participação}

Neste subtópico, cada um dos projetos elencados pela presente dissertação é organizado em um único quadro: as instituições executoras ou responsáveis, se possuem conselhos, se há a participação da sociedade civil, a relação com APA VRT (seja no conselho gestor ou no CONSEMA) e os impactos esperados de cada projeto. 
Quadro 9 - Síntese dos planos, programas e projetos e a participação social

\begin{tabular}{|c|c|c|c|c|c|c|}
\hline $\begin{array}{l}\text { Instituição } \\
\text { Executora/Principal }\end{array}$ & Plano/Projeto & $\begin{array}{l}\text { Existênc } \\
\text { ia de } \\
\text { Conselh } \\
\text { o }\end{array}$ & $\begin{array}{l}\text { Participação da } \\
\text { Sociedade Civil }\end{array}$ & $\begin{array}{c}\text { Participa do } \\
\text { Conselho Gestor } \\
\text { da APA }\end{array}$ & $\begin{array}{l}\text { Membro } \\
\text { do } \\
\text { CONSE } \\
\text { MA }\end{array}$ & $\begin{array}{c}\text { Impacto na } \\
\text { APA }\end{array}$ \\
\hline Fundação Florestal & $\begin{array}{l}\text { Plano de } \\
\text { Manejo da } \\
\text { APA VRT }\end{array}$ & Sim & $\begin{array}{c}\text { Conselho Gestor, } \\
\text { Oficinas Participativas }\end{array}$ & Sim & Sim & Alto \\
\hline EMPLASA & PDUI & Sim & $\begin{array}{l}\text { Comitê Executivo, } \\
\text { Comissão Técnica, } \\
\text { Audiência Pública }\end{array}$ & Sim & Não* & Alto \\
\hline SABESP & $\begin{array}{c}\text { Projeto Tietê } \\
\text { IV }\end{array}$ & Não & Audiências Públicas & Não & Não & Baixo \\
\hline DERSA & Rodoanel & Não & Audiência Pública & Não & Não* & Médio/Alto \\
\hline EPL e DERSA & Ferroanel & - & Audiência Pública & Não & Sim & Baixo \\
\hline $\begin{array}{c}\text { Departamento } \\
\text { Hidroviário (SELT) }\end{array}$ & Hidroanel & - & - & Não & Sim & Alto \\
\hline CPLA-SMA & ZEE & Sim & $\begin{array}{l}\text { Audiências Públicas, } \\
\text { Fóruns Consultivos } \\
\text { Regionais, Mesas de } \\
\text { Diálogos }\end{array}$ & Sim & Sim & Médio \\
\hline СРTM & Linha 13 & - & - & Não & Não* & Médio \\
\hline DAEE & PVT & $\operatorname{Sim}^{28}$ & - & $\begin{array}{c}\text { Sim (durante dois } \\
\text { biênios) }\end{array}$ & Não* & Alto \\
\hline
\end{tabular}

*Apesar de não representados diretamente, as secretarias aos quais estão subordinadas fazem parte do CONSEMA

Elaborado pelo autor

Analisando o quadro, destaca-se que esses diversos planos e projetos possuem, em sua maioria, espaços de participação para a sociedade civil. Aspecto importante e que garante

${ }^{28} \mathrm{O}$ Conselho Estratégico do PVT é constituído somente por representantes do poder público. 
a legitimidade do processo, contudo, considerando os processos analisados pela presente pesquisa, esses múltiplos espaços pelos dados obtidos apresentam majoritariamente representações distintas da sociedade. Outro elemento a ser analisado são os diferentes graus de participação de cada plano ou projeto, a existência de conselhos e como impactam a APA da Várzea do rio Tietê. Verifica-se, então, uma grande diferença da governança executada pelas instituições, dos espaços e da forma que a sociedade é convidada a participar nestes processos.

Relativo à participação, as instituições políticas conseguem participar de muitas dessas arenas, enquanto que a sociedade civil não está representada nesses diversos planos e projetos. As poucas exceções e que possui maior capacidade de participar da maioria dessas arenas são a Federação das Indústrias de São Paulo e o Centro das Indústrias de São Paulo. Haja vista os diferentes grupos que conseguem participar dos processos decisórios, algumas arenas têm a participação majoritária do poder público e, com maior gravidade, planos e projetos que podem ser interrompidos conferem uma grande complexidade na governança do território da APA. Neste aspecto, então, fica o questionamento da possibilidade de se articular todos esses processos e se a sociedade é capaz de acompanhar e interferir nos processos territoriais. 


\section{6- Conclusão}

A presente pesquisa suscita uma série de questionamentos relativos não só ao funcionamento da APAVRT, como também aspectos relativos ao rebatimento das políticas públicas no território. Nesse debate, é importante verificar como interagem as políticas territoriais e setoriais explorados pela pesquisa. No que se refere à APA, não se pode deixar perceber que, para o território analisado, há, em um primeiro momento, um forte caráter fragmentário das políticas públicas, o que potencializa a ação de algumas instituições em detrimento de outras e dificulta o controle e acompanhamento da sociedade a essas políticas públicas. No decorrer da pesquisa, também se verificou, pelas articulações institucionais e pela elaboração dos diferentes planos, que existe um esforço mais estruturado de articulação para as políticas de infraestrutura, enquanto que para os planos e projetos ambientais há uma maior indefinição, conflitos ou enfraquecimento.

O território e a sobreposição dos diversos territórios (como apropriação do espaço por cada ator) é crucial para entender o território da APA, que se articula e sofre pressão dessas outras territorializações. Nesse âmbito, para verificar o caráter integrador (dos conflitos e de sinergias) do território foi necessária a análise espacial, pois essas sobreposições e conflitos não ocorrem de forma homogênea, mas concentrada em algumas porções do território. No caso da APA, chama a atenção a concentração ser majoritariamente em São Paulo, com uma diminuição gradual a medida que segue para os municípios a leste. As sínteses cartográficas apresentadas no capítulo 4 demonstram que a maior concentração de projetos se estende até o município de Itaquaquecetuba e, com um menor grau, até Suzano. No entanto, essa concentração é exclusivamente do poder estadual; caso sejam observadas as pressões municipais, Mogi das Cruzes tem um foco de pressão importante na região leste.

Nesse debate das sobreposições, também é importante considerar os discursos que justificam e legitimam as políticas públicas distintas. Cada discurso é atrelado à uma lógica distinta e, ao se sobreporem, essas lógicas se tornam incompatíveis. O discurso de sustentabilidade, que será recorrente em todos os planos e projetos analisados e com alto grau de conflito, é um aspecto que predomina entre os paradigmas, como é observado nos debates relativos ao Plano de Macrodrenagem no PBHAT.

No campo das políticas públicas, há também diversas questões provocadas, principalmente ao tratar da complexidade de se comparar e acompanhar no território políticas 
que se enquadram em diferentes modelos (participativa, top-down, garbage can etc.), além da capacidade de cada instituição se apropriar do espaço à revelia dos interesses de outras organizações. Considerada a contribuição da análise de políticas públicas, verifica-se a importância dos mecanismos e modos como ocorrem as sobreposições e as disputas de poder para se apropriar do território. Esses mecanismos podem ser verificados pelo desenho e capacidade institucional, pelos processos políticos que podem ou não envolver a sociedade, pelas pessoas que podem ter capacidade de impactar atividade das instituições e pelos tipos de políticas que podem ter maior celeridade ou serem vagarosas em sua execução.

A governança é outro elemento preponderante considerado essencial para a legitimidade e a não suspensão dos processos políticos. Confrontados os diferentes planos e projetos, evidencia-se que para o mesmo território existem múltiplas arenas de decisão das quais algumas tem maior impacto na transformação territorial. A julgar pela invalidação do Plano de Manejo, há uma invalidação do que foi acordado nesta arena, enquanto outras arenas terão as suas decisões efetivadas ou deslegitimadas. Nesse contexto, surgem questionamentos sobre quais arenas terão as suas decisões mais adotadas ou terão suas decisões invalidadas ou suprimidas.

Nesse escopo de discussões, surgem questionamento sobre qual governança existe e que pouquíssimas instituições da sociedade civil conseguem participar em mais de uma arena política dos planos, programas e projetos analisados pela pesquisa. Nesse âmbito, existem então problemas relativos de quem legitimará ou irá interferir em cada uma das políticas. Além do questionamento de qual paradigma está associado com cada alternativa proposta, haja vista que as soluções para as planícies de inundação podem ser no sentido de grandes obras estruturais no território da APA ou em tentar compatibilizar e recuperar o serviço ecossistêmico de atenuação das inundações.

Por fim, essa pesquisa não esgota todas as alternativas e consequências desses aspectos combinados (território, políticas públicas e a governança), mas contribui para entender o processo que se verifica no território da APA da Várzea do Rio Tietê. Nesse sentido, a análise desses elementos contribui para verificar o processo desses conflitos, analisar com maior profundidade as mudanças ocorridas no território da APA, as dificuldades do funcionamento da própria APA e os mecanismos pelos quais se interfere e limita a capacidade de ação da APAVRT. 


\section{Referências}

AB'SABER, A. Zoneamento ecológico e econômico da Amazônia: questões de escala e método. Revista de Estudos avançados, São Paulo, v. 3, n. 5, Apr. 1989. Disponível em: $<$ http://www.scielo.br/scielo.php?script=sci_arttext\&pid=S0103$40141989000100002 \& \operatorname{lng}=\mathrm{en} \& \mathrm{nrm}=\mathrm{iso}>$. Acesso em: 20/02/2015.

AE. Agência Estado. Governo federal quer obra de ferrovia no Rodoanel de SP. O Estado de São Paulo, São Paulo, 1 de abr. 2013. Disponível em: $<$ http://economia.estadao.com.br/noticias/geral,governo-federal-quer-obra-de-ferrovia-norodoanel-de-sp, $149024 \mathrm{e}>$

AMENDOLA, P. V. G. Alckmin dá pasta ao PP após partido apoiar João Doria. O Estado de São Paulo, São Paulo, 19 de jul. 2016. Política. Disponível em: < https://politica.estadao.com.br/noticias/eleicoes,alckmin-da-pasta-ao-pp-apos-partidoapoiar-joao-doria,10000063684>

ANA. Agência Nacional de Águas. Prevenção e Mitigação de Eventos Hidrológicos Críticos: Atlas de Vulnerabilidade a Inundações. Joinville, 26 de setembro de 2013. Disponível em: $<$ http://www.mi.gov.br/c/document library/get file?uuid=8d9e33ed-fbde-4438-a7b2$\underline{1 \mathrm{f} 6 \mathrm{e} 305 \mathrm{fc} 50 \mathrm{e} \& \text { groupId }=185960>}$.

APQC. Associação dos Pesquisadores Científicos do Estado de São Paulo. Carta Aberta de despedida a um anti-gestor da SMA. 2017. Disponível em: $<$ http://www.apqc.org.br/files/Carta-Aberta-APqC_JAAF-despedida-SMA-ago2017.pdf>

BECKER, B. K.; EGLER, C. A. G. .Detalhamento da Metodologia para a Execução do Zoneamento Ecológico-Econômico pelos Estados da Amazônia Legal. 1. ed. Brasília: MMA/SAE, 1997. 43p.

BERTONE, L. F.; MELLO-THÉRY, N. A. de. Perspectiva do ordenamento territorial no Brasil: dever constitucional ou apropriação política. In: STEINBERGER, Marília. (Org.). Território, ambiente e políticas públicas espaciais. Brasília: Paralelo 15 e LGE Editora, 2006, p. 125-147. 
BONNEMAISON, J. Voyage autour du territoire. L'Espace géographique, tome $10, \mathrm{n}^{\mathbf{0}} 4$, 1981, p. 249-262. Disponível em: <https://www.persee.fr/doc/spgeo_00462497_1981_num_10_4_3673>

BORGES, L. R. M. Políticas territoriais na fronteira: o Programa de Aceleração do Crescimento e as transformações em Rondônia no início do séc. XXI. 2012. Dissertação (Mestrado em Geografia Humana) - Faculdade de Filosofia, Letras e Ciências Humanas, Universidade de São Paulo, São Paulo, 2012. doi:10.11606/D.8.2012.tde-07122012-095454.

BOURDIEU, P. Espaço físico, espaço social e espaço físico apropriado. Revista de Estudos avançados, São Paulo, v.27, n.79, 2013.

BRASIL. Lei $n^{\circ}$ 6.938, de 31 de agosto de 1981. Dispõe sobre a Política Nacional do Meio Ambiente, seus fins e mecanismos de formulação e aplicação, e dá outras providências. Disponível em: <http://www.planalto.gov.br/ccivil_03/leis/16938.htm> Lei ${ }^{0}$ 8.625, de 12 de fevereiro de 1993. Institui a Lei Orgânica Nacional do Ministério Público, dispõe sobre normas gerais para a organização do Ministério Público dos Estados dá outras providências. Disponível em: $<$ http://www.planalto.gov.br/ccivil_03/Leis/L8625.htm> . Lei $\mathrm{N}^{\mathrm{o}} 9.985$, de 18 de Julho de 2000. Regulamenta o art. 225, § 1o, incisos I, II, III e VII da Constituição Federal, institui o Sistema Nacional de Unidades de Conservação da Natureza e dá outras providências. Disponível em: $<$ http://www.planalto.gov.br/ccivil_03/leis/19985.htm"http://www.planalto.gov.br/ccivil_03 /leis/19985.htm>.

. Decreto $\mathrm{n}^{\circ} 4.297$, de 10 de julho de 2002. Regulamenta o art. 9o, inciso II, da Lei no 6.938, de 31 de agosto de 1981, estabelecendo critérios para o Zoneamento EcológicoEconômico do Brasil - ZEE, e dá outras providências. Disponível em: $<$ http://www.planalto.gov.br/ccivil 03/decreto/2002/d4297.htm>. Acesso em: 
CABRAL, E.; JESUS, E. F. R. Eventos pluviais concentrados sobre a grande São Paulo ocorridos em 1991: seus reflexos na vida urbana. Sitientibus. Revista da Universidade Estadual de Feira de Santana, v. 12, p. 31-54, 1994.

CAHN. The players: institucional and noninstitucional actors in the policy process. In: THEODOUlOU, S. Z.; CAHN, M. A. Public Policy: the essential readings. UpperSaddle River: Prentice Hall, 1995. p.201-2011

CÂMARA, G.; CARVALHO, M. S.; DRUCK, S.; MONTEIRO, A. M. Análise Espacial e Geoprocessamento. IN: DRUCK, S.; CARVALHO, M.S.; CÂMARA, G.; MONTEIRO, A.V.M. (eds). Análise Espacial de Dados Geográficos. Brasília, EMBRAPA, 2004, p. 21 52.

CAPELHUCHNIK, L. H. Projeto de Hidroanel Metropolitano projetado por grupo de pesquisa da FAU avança. Agência Universitária de Notícias, São Paulo, 17 de fev. 2016. Sociedade, ano 49,ed. $\mathrm{n}^{\mathrm{o}}$ : $14 . \quad$ Disponível em: $<$ http://www.usp.br/aun/antigo/exibir?id=7441\&ed=1296\&f=31>.

FPH. Frente Parlamentar das Hidrovias. Relatório II - 2008-2010. João Caramez (coord.). São Paulo: ALESP, 2010. Disponível em: <http://joaocaramez.com.br/wpcontent/uploads/2010/08/Relatorio_2008_2010_FPH_1808101.pdf> . Relatório III - 2011/2012. João Caramez (coord.). Diário Oficial, Legislativo, São Paulo, 1 de mar. 2013. Disponível em: < https://www.imprensaoficial.com.br/DO/BuscaDO2001Documento_11_4.aspx?link=/2013/ legislativo/marco/01/pag_0014_9PJ0JDAKONF3Ge3EVQ7BIJACB91.pdf\&pagina=14\&d ata $=01 / 03 / 2013 \&$ caderno $=$ Legislativo\&paginaordenacao $=100014>$

CASTRO, I. E..Geografia e política. Território, escalas de ação e instituições.. 1. ed. Rio de Janeiro: Bertrand Brasil, 2005. v. 1. 299p.

CERON, A. O. Classificações espaciais e regionalização. Boletim de Geografia Teorética, vol. $7, \mathrm{n}^{\circ} 14,1977$. 
CETENCO. Cetenco Engenharia S.A. Obras recentes: Eclusa da Barragem da Penha. Disponível em: <http://www.cetenco.com.br/br/obras/em-andamento/154>

CETESB. Companhia Ambiental do Estado de São Paulo. Licença ambiental de instalação $\mathbf{n}^{\mathbf{0}}$ 2224. Processo $\mathrm{n}^{\mathrm{o}}$ 13.735/2007. São Paulo: CETESB, 2013. Disponível em: $<$ http://www.cptm.sp.gov.br/sustentabilidade/Documents/LI_2224.pdf $>$.

Parecer técnico $N^{0}$.

79977/10/TA. São Paulo: CETESB, 2010. Disponível em: < http://arquivos.ambiente.sp.gov.br/consema/2011/11/oficio_consema_2010_096/Parecer_T ecnico_CETESB_79977_10-TA.pdf>

CHRISTOFOLETTI, A. As características da nova geografia. In: . Perspectivas da Geografia. São Paulo: Difel, 1982. p.71-

101.

CREPANI, E.; MEDEIROS, J. S. de; FILHO, P. H.; FLORENZANO, T. G.; DUARTE, V.; BARBOSA, C. C. F. Sensoriamento remoto e geoprocessamento aplicados ao Zoneamento Ecológico-Econômico e ao ordenamento territorial. São José dos Campos: INPE, 2001.

CORRÊA, R. L. Região e Organização Espacial. São Paulo: Editora Ática, 2003. $7^{\mathrm{a}}$ ed. Série Princípios.

CORREIO DA MANHÃ. Anel Ferroviário será solução para São Paulo. Correio da Manhã, Diretor Econômico, Rio de Janeiro, 29 de set. 1970,Disponível em: $<$ http://memoria.bn.br/DocReader/Hotpage/HotpageBN.aspx?bib=089842_08\&pagfis=120 91\&url=http://memoria.bn.br/docreader\#>

CÔRTE, D. A. de A. Planejamento e gestão de APAs: enfoque institucional. Brasília : Instituto Brasileiro do Meio Ambiente e dos Recursos Naturais Renováveis, 1997. 106 p. Série Meio Ambiente em Debate; 15.

COSTA, G. B. da. Consciência, Participação e Negociação: uma leitura psicopolítica do processo de produção do Plano de Manejo da APA Várzea do Rio Tietê. 2012. 
Dissertação (Mestrado em MUDANÇA SOCIAL E PARTICIPAÇÃO POLÍTICA) Universidade de São Paulo.

COSTA, W. M. da. Geografia política e geopolítica: discursos sobre território e o poder. 2 ed. 3 reimpressão. São Paulo: EDUSP, 2016.

CUNHA, L. H.; COELHO, M. C. N. Política e Gestão ambiental. In: CUNHA, S. B.; GUERRA, A. J. T. (orgs.). A questão ambiental: diferentes abordagens. Rio de Janeiro: Bertrand Brasil, 2003. p. 43-79.

DAEE. Departamento de Água e Energia Elétrica. Programa de Recuperação das Várzeas da Bacia do Alto Tietê (BR-L 1216): Plano diretor de Reassentamento. São Paulo: DAEE, 2010. Disponível em: $<$ http://www.saneamento.sp.gov.br/varzea_bid/PDR\%20vers\%C3\%A30\%2027_05_10_se $\underline{\mathrm{m} \% 20 \log 0 \% 20 \mathrm{BID} . \mathrm{pdf}>}$. Acesso em:

. Departamento de Água e Energia Elétrica . 2016. Disponível em: <http://www.daee.sp.gov.br/ >

DELIJAICOV, A. Os rios e o desenho da cidade: proposta de projeto para a orla fluvial da grande São Paulo. 1998. Dissertação (Mestrado em Estruturas Ambientais Urbanas) Universidade de São Paulo.

DH. Departamento Hidroviário. Extrato de aditivo. Contrato $n^{\circ}$ DH-091/2013 - Processo $n^{\circ}$ DH-376/2012. Diário Oficial, Poder Executivo, Seção I, São Paulo, 17 de set. 2015. p. 230.

DINIZ, J. N. B.. Representação do Tietê na Historiografia Paulista. Revista LatinoAmericana de História, v. 2, p. 126-140, 2013.

DYE, T R. Understanding public policy. 12 ed. New Jersey: Pearson/Prentice Hall, 2008.

EMPLASA. Empresa Paulista de Planejamento Metropolitano S/A. Plano de ação da macrometrópole paulista 2013-2040: o futuro das metrópoles. São Paulo: EMPLASA, 2017. 
Desenvolvimento Urbano Integrado da Região Metropolitana de São Paulo: Caderno preliminar, propostas. São Paulo: EMPLASA, 2017.

EPL. Empresa de Planejamento e Logística S.A. DERSA. Desenvolvimento Rodoviário S.A. PRIME ENGENHARIA. Ferroanel Norte: Contorno Ferroviário da Região Metropolitana de São Paulo. Relatório de Impacto Ambiental. São Paulo: Prime Engenharia, 2017.

ESCOBAR, H. Secretário de Meio Ambiente critica ambientalistas e defende 'reequilíbrio' com o setor produtivo. Estadão, Blogs Imagine Só!, 22 març. 2017a. Disponível em: $<$ http://ciencia.estadao.com.br/blogs/herton-escobar/secretario-de-meio-ambiente-criticaambientalistas-e-defende-reequilibrio-de-oportunidades-para-o-setor-produtivo/>

.Agrônomo assume gerência de 18 unidades de conservação da Mata Atlântica em SP. Estadão, Blogs Imagine só!, 11 maio 2017b. Disponível em: $<\mathrm{http}$ //ciencia.estadao.com.br/blogs/herton-escobar/agronomo-assume-gerencia-de-18unidades-de-conservacao-da-mata-atlantica-em-sp/>

FAISSOL, Speridião. Teorização e quantificação em Geografia. RBG, vol. 34, 1972, nº 1, p.145-164.

. Teorização e quantificação em Geografia. RBG, vol. 40, nº 1, 1978, p.3-50.

FERNANDES, B. M.. Por uma tipologia de territórios. In: Saquet, M. Sposito, E..(Org.). Território e territorialidades: teorias processos e conflitos. 2ed. Rio de Janeiro: Consequência, 2015, v. 2, p. 44-66.

FF - Fundação para a Conservação e a Produção Florestal do Estado de São Paulo. Plano de Manejo APA Várzea do Rio Tietê - Volume 1 - Principal. 5 vol. São Paulo, 2013.

FOUCAULT, M. De espaços outros. Revista de Estudos avançados, São Paulo, v. 27, n. 79, 2013. 
FRANCO, F. de M. A Construção do caminho: a estruturação da metrópole pela conformação técnica das várzeas e planícies fluviais da Bacia de São Paulo. 2005. Tese (Doutorado em Arquitetura e Urbanismo) - Universidade de São Paulo.

FREDERICO, C. de S. Do planejamento tradicional de transporte ao moderno plano integrado de transportes urbanos. São Paulo Perspec., São Paulo, v. 15, n. 1, p. 45-54, Jan. 2001 . Disponível em: <http://www.scielo.br/scielo.php?script=sci_arttext\&pid=S0102$88392001000100006 \& \operatorname{lng}=$ en \&nrm=iso $>$

FREHSE, F. O espaço na vida social: uma introdução. Revista de Estudos avançados, São Paulo, v. 27, n. 79, 2013.

FREY, K. Políticas públicas: um debate conceitual e reflexões referentes à prática da análise de políticas públicas no Brasil. Planejamento e Políticas Públicas, Brasília, nº 21, p 211259, jun. 2000.2 Disponível em: $<$ http://www.ipea.gov.br/ppp/index.php/PPP/article/view/89>. Acesso em:

GALVÃO, Marília Velloso; FAISSOL, Speridião. A revolução quantitativa na Geografia e seus reflexos no Brasil. RGB, vol. 32, 1970, nº 4, p.5-22.

GARTLAND, L. O que é uma ilha de calor? In: GARTLAND, L. Ihas de calor: como mitigar zonas de calor em áreas urbanas. Tradução Silvia Helena Gonçalves. São Paulo: Oficinas de Textos, 2010.

GIRARDI, G. MP vê tentativa de intimidação por parte de secretário de Ambiente em sindicância. O Estado de São Paulo, Blogs Ambiente-se, 24 de mar. 2017. Disponível em: $<$ http://sustentabilidade.estadao.com.br/blogs/ambiente-se/mp-ve-tentativa-de-intimidacaopor-parte-de-secretario-de-ambiente-em-sindicancia/ > . MP abre novo inquérito de improbidade contra secretário de Ambiente de SP por venda de florestas. O Estado de São Paulo, Sustentabilidade, 24 de mar. 2017. Disponível em: <https://sustentabilidade.estadao.com.br/noticias/geral,mp-abre-novoinquerito-de-improbidade-contra-secretario-de-ambiente-de-sp-por-venda-deflorestas,70001713366> 
GUIMARÃES, M. S. G. Divisão Regional do Brasil. Rio de Janeiro: IBGE, 1942, 49p.

Observações sôbre o problema da divisão regional. Revista Brasileira de Geografia, vol.25, nº 3, p.289-311, jul./set. 1963.

GRIGG, D. Regiões, classes e modelos. In: CHORLEY, Richard; HAGGET, Peter. Modelos integrados em Geografia. Rio de Janeiro: Livros Técnicos e Científicos, 1974.

HARTSHORNE, R. Propósitos e Natureza da Geografia. São Paulo: Editora Hucitec /Edusp, 1978, 2ª edição, 203p.

HOLTZ, A. C. T. Programa Parque Várzeas do Tietê. Informe de Avaliação Intermediaria Empréstimo BID 2500/OC-BR (BR-L 1216). São Paulo: DAEE, 2015.

IACOVINI, R. F. G. Rodoanel Mario Covas: atores, arenas e processos. 2013. Dissertação (Mestrado em Planejamento Urbano e Regional) - Faculdade de Arquitetura e Urbanismo, Universidade de São Paulo, São Paulo, 2013.

ISODA, M. K. de T. e. Transporte sobre trilhos na Região Metropolitana de São Paulo: estudo sobre a concepção e inserção das redes de transporte de alta capacidade. 2013. Dissertação (Mestrado em Planejamento Urbano e Regional) - Faculdade de Arquitetura e Urbanismo, Universidade de São Paulo, São Paulo, 2013.

JACOBI, P. Poder Local, Políticas Sociais e Sustentabilidade. Saúde e Sociedade. São Paulo, v. 8, n.1, p.31-48, 1999.

JORGE, J. São Paulo das enchentes, 1890-1940. Histórica (São Paulo. Online), v. 47, p. 103-124, 2011. . Rios e Saúde na Cidade de São Paulo, 1890-1940. História \& Perspectivas (Online), v. 24, p. 103-124, 2012.

. Tietê: o rio que a cidade perdeu. São Paulo, 1890-1940. 2 ed.São Paulo: SVMA, 2017. 232p . 
JUILLARD, E. La region: ensayo de definicion. In: MENDOZA, Gomez Josefina (et all). El pensamiento geográfico: estudio interpretativo y antología de textos: (de Humboldt a las tendencias radicales). Madrid: Alianza Editorial, p.289-302.

LARA, W. Justiça de SP anula novo zoneamento de área de proteção ambiental do Tietê. G1, São Paulo, 13 de jun. 2018. Disponível em: <https:/g1.globo.com/sp/saopaulo/noticia/justica-de-sp-anula-novo-zoneamento-de-area-de-protecao-ambiental-dotiete.ghtml>

LAURIER, E. Participant observation. IN: CLIFFORD, N.;FRENCH, S.; VALENTINE, G. (eds.). Key Methods in Geography. 2 ed. Los Angeles, London, New Delhi, Singapore, Washington DC: SAGE Publications, 2012, p. 116-130.

LEFEBVRE, H. Prefácio: a produção do espaço. Revista de Estudos avançados, São Paulo, v.27, n.79, 2013.

LEITE, F. Superintendente da Sabesp critica abertura de capital da empresa. O Estado de São Paulo, São Paulo, 26 de fev. 2015a. Disponível em: < http://saopaulo.estadao.com.br/noticias/geral,superintendente-da-sabesp-critica-abertura-de-capitalda-empresa,1640519>

. Trecho leste do Rodoanel é concluído com 15 meses de atraso. O Estado de São

Paulo, São Paulo, 26 de jun. 2015b. Disponível em: < paulo.estadao.com.br/noticias/geral,trecho-leste-do-rodoanel-e-concluido-com-15-mesesde-atraso, $1713755>$

. Secretário do Meio Ambiente manda retirar busto de Lamarca de parque estadual. O Estado de São Paulo, São Paulo, 10 de ago. 2017. Política. Disponível em: < https://politica.estadao.com.br/noticias/geral,secretario-do-meio-ambiente-manda-retirarbusto-de-lamarca-de-parque-estadual,70001932171 >

LIMA JUNIOR, O. B. de. As reformas administrativas no Brasil: modelos sucessos e fracassos. Revista do Serviço Público, ano 49, n. 2, p. 5-32, abr./jun. 1998. 
LITTLE, P. E. Os conflitos socioambientais: um campo de estudo e de ação política. In: BURSZTYN, M. (Org.). A difícil sustentabilidade: política energética e conflitos ambientais. Rio de Janeiro: Garamond Universitária, 2001, v. , p. 107-122.

MARCH, J. G; OLSEN, J. P. Neo-institucionalismo: fatores organizacionais na vida política. Rev. Sociol. Polit. Tradução de Gustavo Rinaldi Althoff.Curitiba , v.16, n.31, p.121-142, Nov. 2008.2 Disponível em:

$<$ http://www.scielo.br/scielo.php?script=sci_arttext\&pid=S0104$44782008000200010 \& \operatorname{lng}=$ en\&nrm=iso $>$. Acesso em: 23/06/2016.

MARCHAND, J. P. Systèmes territoriaux et risques climatique. In : LAMARRE, Denis (Org.) Les risques climatiques. Paris: Belin, 2002, pp. 65-78.

MARQUES, E. C. Redes sociais, instituições e atores políticos no governo da cidade de São Paulo. São Paulo : Annablume ; FAPESP, 2003. 248p.

MASSARDIER, G. Politiques et actions publiques. Paris: Armand Colin, 2003. p. 302.

MC. Ministério das Cidades. IPT. Instituto de Pesquisas Tecnológicas. Mapeamento de riscos em encostas e margem de rios. Brasília: Ministério das Cidades; Instituto de Pesquisas Tecnológicas, 2007.

MELLO-THÉRY, N. A. de. Política (e ação) pública, território e o papel da geografia. Revista da ANPEGE, v. 7, p. 11-19, 2011a. . Território e gestão ambiental na Amazônia. Terras públicas e os dilemas do Estado. 1a.. ed. São Paulo: Annablume, 2011b. 198p

MONTEIRO, P. R. São Paulo no centro das marginais: a imagem paulistana refletida nos Rios Pinheiros e Tietê. 2010. Tese (Doutorado em Design e Arquitetura) - Faculdade de Arquitetura e Urbanismo, Universidade de São Paulo, São Paulo, 2010. doi:10.11606/T.16.2010.tde-17062010-152626. Acesso em: 2018-04-25. 
MORAES, A. C. R. Introdução: a antropogeografia de Ratzel: indicações. IN: MORAES, A. C. R. (org.). Ratzel Geografia.Tradução Fátima Murad e Denise Bottman. Coleção grandes cientistas sociais. São Paulo: Ática, 1990.

MORI, L. Por que São Paulo ainda não conseguiu despoluir o rio Tietê? BBC Brasil, São Paulo, 04 de dez. 2017. Disponível em: <http://www.bbc.com/portuguese/brasil-42204606>

MOROZ-CACCIA GOUVEIA, I. C. A cidade de São Paulo e seus rios: uma história repleta de paradoxos. Confins (Paris), p. 1-18, 2016.

MOURA, A. M. M.. Trajetória da política ambiental federal no Brasil. In: MOURA, Adriana M.M.. (Org.). Governança ambiental no Brasil: instituições, atores e políticas públicas. 1aed.Brasília: Ipea, 2016, v. único, p. 13-44.

MPSP. Ministério Público do Estado de São Paulo. Justiça concede liminar ao MP e suspende obras do "Expresso Aeroporto". Notícias MPSP, 9 de jul. 2009. Disponível em: $<$ http://www.mpsp.mp.br/portal/page/portal/noticias/publicacao_noticias/2009/jul09/Justi\% C3\%A7a\%20concede \%20liminar\%20ao\%20MP\%20e\%20suspende $\% 20$ obras\%20do\%20\% E2\%80\%9CExpres>

. IP 0028660-58.2017.São Paulo:

MPSP, 2017b Disponível em:

$<$ http://www.folhadedourados.com.br/base/www/folhadedourados.com.br/media/attachmen ts/102/102/59a9a86468d8afde7beb96168c2412d11007129666ef5_orgao-especial-004182276.2017.8.26.0000-pecas-relevantes-mpe-e-distribuicao-procedimento-criminal-ricardosalles-advocacia-administrativa-bueno-netto.pdf $>$ 
OLIVEIRA, K. S. História do MPSP: Breve história do Ministério Público do Estado de São Paulo. Projeto Memorial MPSP, 2013 Disponível em: $<$ http://www.mpsp.mp.br/portal/page/portal/MemorialMPSP/historia_do_mpsp>

PAGANINI, W. da S. A identidade de um rio de contrastes: o Tietê e seus múltiplos usos. 2 ed. São Paulo: ABES, AESABESP, 2008. 256p.

PDUI. Plano de Desenvolvimento Urbano Integrado. Regulamento Assembléia Pública Para Escolha de Representantes da Sociedade Civil para o Comitê Executivo e Comissão Técnica do Plano de Desenvolvimento Urbano Integrado - PDUI da Região Metropolitana de São Paulo - RMSP. Disponível em: $<$ https://drive.google.com/file/d/0B1GWvY9rzeBaENTR0Jwamc0NkE/view>

PEREIRA, R. Governos federal e de SP decidem que Ferroanel terá 3 trechos de $200 \mathrm{~km}$. O Estado de São Paulo, 18 de jul. 2012. Disponível em: $<$ http://economia.estadao.com.br/noticias/geral,governos-federal-e-de-sp-decidem-queferroanel-tera-3-trechos-de-200-km,119696e>

PETRONE, P. A cidade de São Paulo no século XX. Revista de História, São Paulo, v. 10, n. 21-22, p. 127-170, junho 1955. ISSN 2316-9141. Disponível em: $<$ http://www.revistas.usp.br/revhistoria/article/view/36445/39168>. Acesso em: 26 jan. 2018.

PIMENTEL, J. C. Projeto do Ferroanel Norte será apresentado em 2017, A Tribuna, 12 de dez. 2016. Disponível em: <http://www.atribuna.com.br/noticias/noticiasdetalhe/porto\%26mar/projeto-do-ferroanel-norte-sera-apresentado-em2017/?cHash=5d0ad4cca03ef00d345886f878e27283>

RAFFESTIN, C. Por uma geografia do poder. Tradução de Maria Cecília França. São Paulo: Atica, 1993.

. Space, territory, and territoriality. Translated by Samuel A. Butler.

Environmentand Planning D: Society and Space, 2012, volume 30, pages 121-141 
. A produção de estruturas territoriais e sua representação. In: SAQUET, M.

A.; SPOSITO, E. S. Território e territorialidades: teorias, processos e conflitos. 2 ed. Rio de Janeiro: Consequência Editora, 20015. p. 13-32.

RATZEL, Friedrich. O solo, a sociedade e o Estado. Tradução de Mario Antonio Enfrásio. Revista do Departamento de Geografia, São Paulo, v. 2, p. 93-101, nov. 2011. Disponível em: <http://www.revistas.usp.br/rdg/article/view/47081/50802>. Acesso em: 03 nov. 2016.

RIBEIRO, W. C.. Gestão das águas metropolitanas. In: CARLOS, Ana; OLIVEIRA, Ariovaldo. (Org.). Geografias de São Paulo: a metrópole do século XXI. São Paulo: Contexto, 2004, v. 2, p. 165-182.

RODRIGUES, C. A urbanização da metrópole sob a perspectiva da Geomorfologia: Tributos a leituras Geográficas. In: CARLOS, A. F; OLIVEIRA, A. U. de. (Org.). As Geografias de São Paulo. São Paulo: DG/Contexto, 2004, v. 1, p. 89-114. . Atributos ambientais no ordenamento territorial urbano. O exemplo das planícies fluviais na Metrópole de São Paulo. GEOUSP: Espaço e Tempo (Online), São Paulo, v. 19, n. 2, p. 324-347, nov. 2015. Disponível em: $<$ http://www.revistas.usp.br/geousp/article/view/102805>. Acesso em: 02 aug. 2016. DOI: $<$ http://dx.doi.org/10.11606/issn.2179-0892.geousp.2015.102805. $>$

RODRIGUES, J. N. Políticas Públicas e Geografia : a retomada de um debate. GEOUSP: Espaço e Tempo (Online), São Paulo, v. 18, n. 1, p. 152-164, apr. 2014. ISSN 2179-0892. Disponível em: <http://www.revistas.usp.br/geousp/article/view/81093/84736>. Acesso em: 30 june 2016.

ROSS, J. L. S.. São Paulo: a cidade e as águas. In: CARLOS, A. F; OLIVEIRA, A. U. de. (Org.). As Geografias de São Paulo. São Paulo: DG/Contexto, 2004, v. 2, p. 183-220.

RUCKERT, A. A. Políticas territoriais, ciência \& tecnologia e a ação de atores locais e regionais: o Pólo de Modernização Tecnológica da Serra - Rio Grande do Sul - Brasil. Sociologias, Porto Alegre, n. 11, p. 148-183, June 2004. Disponível em: 
$<$ http://www.scielo.br/scielo.php?script=sci_arttext\&pid=S1517-

$45222004000100008 \& \operatorname{lng}=\mathrm{en} \& \mathrm{nrm}=\mathrm{iso}>$.

SABESP. Companhia de Saneamento Básico do Estado de São Paulo. Projeto Tietê: CONESAN Julho/16. Disponível em: $<$ http://www.saneamento.sp.gov.br/Anexos_Conesan/Apresentacoes/APRESENTACAO\% 20PROJETO\%20TIETE.pdf>

- Governança

corporativa e padrões NYSE. Disponível em:

$<$ http://www.sabesp.com.br/CalandraWeb/CalandraRedirect/?temp=4\&proj=investidoresno vo $\& p u b=T \& d b=\& d o c i d=091309 F A 45562 D D E 832570 D F 006 A D 419 \& d o c i d P a i=2 F E 7635$ D7BAB1A2F8325768C0051E721\&pai=filho0\&filho=neto-1 >. Acesso em: 05/05/2018a.

Avaliação ambiental e social (AAS) e marco de gestão ambiental e social (MGAS) do programa de despoluição do rio Tietê - Etapa IV (Tietê IV): Plano para realização de consulta comunitária. São Paulo: SABESP, 2018 b.

SANGUIN, A. L.La géographie politique. 1 ed. Paris: PUF, 1977. p. 183.

. A evolução da Geografia Política desde os anos de 1990: uma perspectiva internacional. Tradução de Camilo Pereira Carneiro Filho. In: SILVA, A. C. P. da (org.). Geografia política, geopolítica e gestão do território: racionalidades e práticas em múltiplas escalas: contribuições do I CONGEO para a pesquisa geográfica no Brasil. Rio de Janeiro: Gramma, 2016. p. 13-64.

SANTIAGO, T. Governo de SP apresenta licenciamento ambiental do Ferroanel Norte. Portal G1, 23 de jun. 2017. Disponível em: <https:/g1.globo.com/saopaulo/noticia/governo-de-sp-apresenta-licenciamento-ambiental-do-ferroanel-norte.ghtml>

SANTOS, A. L. Paisagem útil: o Rio Tietê e a urbanização paulistana (1966 - 1986). 2014. Dissertação (Mestrado em Teoria e História da Arquitetura e do Urbanismo) - Instituto 
de Arquitetura e Urbanismo, Universidade de São Paulo, São Carlos, 2014. Disponível em: $<$ http://www.teses.usp.br/teses/disponiveis/102/102132/tde-20012015-093731/pt-br.php>

SANTOS, F. A. dos. Domando as águas: salubridade e ocupação do espaço na cidade de São Paulo, 1875-1930. São Paulo: Alameda, 2011. 324 p.

SANTOS, M. Espaço e Método. 5 ed. 2 reimpressão. São Paulo: EDUSP, 2014. (Coleção Milton Santos)

SÃO PAULO (estado). Lei $\mathrm{n}^{\circ}$ 1350, de 12 de dezembro de 1951. Cria e organiza o Departamento de Águas e Energia Elétrica, como, autarquia estadual, extingue a Inspetoria de Serviços Públicos, da Secretaria - de Viação e Obras Públicas e dá outras providências. Disponível em:

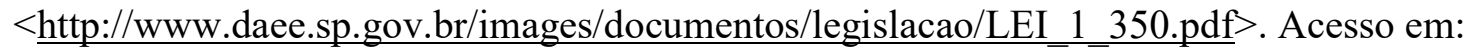
Lei $\mathrm{n}^{\circ}$ 9.318, de 22 de abril de 1966. Dispõe sobre a estruturação da Secretaria dos Transportes e dá outras providências. Disponível em: < https://www.al.sp.gov.br/repositorio/legislacao/lei/1966/lei-9318-22.04.1966.html>

Decreto lei $\mathrm{n}^{\mathrm{o}} 5$, de 6 de março de 1969. Dispõe que o Poder Executivo promovera a constituição e organização de uma sociedade por ações sob a denominação de "DERSA - Desenvolvimento Rodoviário S/A" e da outras providências. Disponível em: $<\underline{\text { http://www.al.sp.gov.br/repositorio/legislacao/decreto.lei/1969/decreto.lei- }}$ 5-06.03.1969.html >. Acesso em:

Lei $n^{\circ} 119$, de 29 de junho de 1973. Autoriza a constituição de uma sociedade por ações, sob a denominação de Companhia de Saneamento Básico do Estado de São Paulo - SABESP, e dá providências correlatas. Disponível em: $<$ https://www.al.sp.gov.br/norma/?id=29185>

Lei complementar estadual no 94, de 29 de maio de 1974. Dispõe sobre a Região Metropolitana da Grande São Paulo, autoriza o Executivo a constituir a Empresa Metropolitana de Planejamento da Grande São Paulo S/A - EMPLASA, institui o Fundo Metropolitano de Financiamento e Investimento - FUMEFI e dá outras providências. 
$<$ https://www.emplasa.sp.gov.br/Cms_Data/Sites/EmplasaDev/Files/fnem/arquivos/Legisla \%C3\%A7\%C3\%A30\%20Regi\%C3\%B5es\%20Metropolitanas/Estado\%20de\%20S\%C3\%A 30\%20Paulo/4.\%20RM\%20S\%C3\%A3o\%20Paulo/2-LeiComplementar94.pdf>

. Decreto Estadual 7.868 de 30 de abril de 1976. Declara de utilidade pública, para fins de desapropriação, áreas de terra situadas em Município da Região da Grande São Paulo, necessárias ao Departamento de Águas e Energia Elétrica do Estado de São Paulo. Disponível em: <http://www.al.sp.gov.br/norma/?id=150141>

. Projeto de Lei no 334 de 1984. Declara Área de Proteção Ambiental regiões urbanas e/ou rurais dos Municípios de Salesópolis, Biritiba Mirim, Mogi das Cruzes, Suzano, Poá, Itaquaquecetuba, Guarulhos, São Paulo, Osasco, Barueri, Carapicuíba e Santana do Parnaíba. Diário Oficial do Estado, São Paulo, SP, 20 de maio de 1986, pg. 5964.

Decreto n. 24.932, de 24 de março de 1986. Institui o Sistema Estadual do Meio Ambiente, cria a Secretaria de Estado do Meio Ambiente e dá providências correlatas.

em:

$<$ http://www.al.sp.gov.br/repositorio/legislacao/decreto/1986/decreto-24932-

24.03.1986.html>

. Lei $\mathrm{n}^{\circ}$ 5.208, de 01 de julho de 1986. Autoriza o Poder Executivo a instituir Fundação denominada "Fundação para a Conservação e a Produção Florestal do Estado de São Paulo". Disponível em: <http://www.al.sp.gov.br/norma/?id=26765>.

. Lei Estadual no 5598, de 06 de janeiro de 1987. Declara Área de Proteção Ambiental regiões urbanas e/ou rurais dos Municípios de Salesópolis, Biritiba Mirim, Mogi das Cruzes, Suzano, Poá, Itaquaquecetuba, Guarulhos, São Paulo, Osasco, Barueri, Carapicuíba e Santana do Parnaíba. Disponível em: $<$ http://www.al.sp.gov.br/repositorio/legislacao/lei/1987/lei-5598-06.02.1987.html> 
Constituição Estadual, de 5 de outubro de 1989. Disponível em:

$<$ http://www.al.sp.gov.br/repositorio/legislacao/constituicao/1989/compilacao-constituicao0-05.10.1989.html>

. Lei $\mathrm{n}^{0} 6.851$, de 03 de maio de 1990. Dispõe sobre a transferência de ações para a Fazenda do Estado e dá providências correlatas. Disponível em: $<$ https://www.al.sp.gov.br/norma/?id=22841>

Lei $n^{0} 7.663$, de 30 de dezembro de 1991. Estabelece normas de orientação à Política Estadual de Recursos Hídricos bem como ao Sistema Integrado de Gerenciamento de Recursos Hídricos. Disponível em: $<$ https:/www.al.sp.gov.br/repositorio/legislacao/lei/1991/lei-7663-30.12.1991.html>

. Lei $\mathrm{n}^{\mathrm{o}} 7.861$, de 28 de maio de 1992. Autoriza o Poder Executivo a constituir a Companhia Paulista de Trens Metropolitanos - CPTM, e dá outras providências. Disponível em: < $\underline{\text { http://www.al.sp.gov.br/repositorio/legislacao/lei/1992/alteracao-lei-7861- }}$ $\underline{28.05 .1992 . h t m l>}$

. Lei complementar $\mathrm{n}^{\mathrm{o}} 734$, de 26 de novembro de 1993. Institui a Lei Orgânica do Ministério Público e dá outras providências. Disponível em: < http://biblioteca.mpsp.mp.br/phl_img/legis/lcp-00734.pdf >

. Lei $\mathrm{n}^{\mathrm{o}}$ 8.523, de 29 de dezembro de 1993. Autoriza o Poder Executivo a alienar ações de propriedade da Fazenda do Estado, na forma que especifica, e dá providências correlatas. Disponível em: $<$ https://www.al.sp.gov.br/norma/?id=14102>

. Decreto $n^{\circ}$ 42.837, de 03 de fevereiro de 1998. Regulamenta a Lei $\mathrm{n}^{0} 5598$, de 06 de fevereiro de 1987, que declara área de proteção ambiental regiões urbanas e rurais ao longo do curso do Rio Tietê, nos Municípios de Salesópolis, Biritiba Mirim, Mogi das Cruzes, Suzano, Poá, Itaquaquecetuba, Guarulhos, São Paulo, Osasco, Barueri, Carapicuíba e Santana do Parnaíba, e dá providências correlatas. Diário Oficial do Estado, Poder Executivo, São Paulo, SP, 4 fev. 1998. Seção 1 p1-23. Disponível em: $<$ http://dobuscadireta.imprensaoficial.com.br/default.aspx?DataPublicacao=19980204\&Ca derno $=$ Executivo $\% 20$ I $\&$ NumeroPagina $=1>$ 
Decreto n. 45.087, de 31 de julho de 2000. Reorganiza o Departamento Hidroviário, da Secretaria dos Transportes, e dá providências correlatas. Disponível em: < https://www.al.sp.gov.br/repositorio/legislacao/decreto/2000/decreto45087-31.07.2000.html>

. Lei ${ }^{\circ} 12.292$, de 02 de março de 2006. Altera a Lei ${ }^{\circ} 119$, de 29 de junho de 1973, que autorizou a constituição de uma sociedade por ações sob a denominação de Companhia de Saneamento Básico do Estado de São Paulo - SABESP, e dá providências correlatas. Disponível em: $<$ https://www.al.sp.gov.br/repositorio/legislacao/lei/2006/lei-12292-02.03.2006.html>

. Decreto No 51.453 , de 29 de Dezembro de 2006. Cria o Sistema Estadual de Florestas - SIEFLOR e dá providências correlatas. Disponível em: $<$ http://www.ambiente.sp.gov.br/legislacao/files/2006/12/DECRETO-N\%C2\%BA-51.453DE-29-DE-DEZEMBRO-DE-2006.pdf>

. Lei complementar $\mathrm{n}^{0} 1.025$, de 07 de dezembro de 2007. Transforma a Comissão de Serviços Públicos de Energia - CSPE em Agência Reguladora de Saneamento e Energia do Estado de São Paulo - ARSESP, dispõe sobre os serviços públicos de saneamento básico e de gás canalizado no Estado, e dá outras providências. Disponível em: $<$ https://www.al.sp.gov.br/norma/?id=74753>

- Aviso de Licitação. Concorrência 003/2016 - Processo 63.088/2016. Imprensa Oficial, 22 de mar. de 2016a. Disponível em: $<$ https://www.imprensaoficial.com.br/Certificacao/GatewayCertificaPDF.aspx?notarizacao $\mathrm{ID}=\mathrm{a} 96246 \mathrm{~b} 8-\mathrm{b} 637-4 \mathrm{e} 42-82 \mathrm{a} 2-467 \mathrm{f} 0 \mathrm{c} 129 \mathrm{~b} 49>$

. Minuta de decreto do plano de manejo APAVRT. Aprova o Plano de Manejo da Área de Proteção Ambiental (APA) da Várzea do Rio Tietê, Unidade de Conservação da Natureza de Uso Sustentável criada pela Lei $n^{\circ}$ 5.598, de 06 de fevereiro de 1987. Versão 29 de nov. 2016 b.

- Projeto de lei $n^{\circ} 199$, de 2018. Dispõe sobre a extinção do Departamento Aeroviário do Estado de São Paulo - DAESP e sobre a transferência das 
atribuições do Departamento Hidroviário e dá providências correlatas. Disponível em: < https://www.al.sp.gov.br/propositura/?id=1000210321>

\section{SATO, D. P. Conflitos Territoriais na Área de Proteção Ambiental da Várzea do Rio}

Tietê. 2013. Orientadora Neli Aparecida de Mello-Théry. Monografia (Bacharelado em Gestão Ambiental) - Universidade de São Paulo.

SCATENA, G. K. Áreas de Proteção Ambiental e os desafios da gestão territorial para a sustentabilidade: o caso da APA da Várzea do Rio Tietê. 2015. Dissertação (mestrado em Planejamento e Gestão do Território) - Universidade Federal do ABC.

SIGRH. Sistema Integrado de Gerenciamento de Recursos Hídricos do Estado de São Paulo. Comitê da Bacia Hidrográfica do Alto Tietê: apresentação. Disponível em: $<$ http://www.sigrh.sp.gov.br/cbhat/apresentacao $>$

SELT - Secretaria Estadual de Logística e Transporte. Hidroanel Metropolitano de São Paulo: articulação arquitetônica e urbanística dos estudo de pré-viabilidade econômica, técnica e ambiental. Alexandre Delijaicov, coordenador. São Paulo: Departamento Hidroviário da Secretaria Estadual de Logística e Transportes, 2011 a.

. Memorial descritivo: articulação

arquitetônica e urbanística dos estudos de pré-viabilidade técnica, econômica e ambiental do Hidroanel metropolitano de São Paulo. Alexandre Delijaicov, coordenador. São Paulo: Departamento Hidroviário da Secretaria Estadual de Logística e Transportes, $2011 b$.

SILVA, A. S. da; et al. Oficinas Participativas na Elaboração do Plano de Manejo da APAVRT. Revista Gestão \& Políticas Públicas, v. 4, p. 240-266, 2014.

SILVA, I. X. da. Gestão das áreas de proteção ambiental - APAs - no Estado de São Paulo: estudo e avaliação. 2006. Dissertação (Mestrado em Geografia Humana) - Faculdade de Filosofia, Letras e Ciências Humanas, Universidade de São Paulo, 2006.

SILVA, S. A. da. O planejamento regional brasileiro pós-constituição federal de 1988: instituições, políticas e atores. São Paulo: Annablume, 2017. 
SILVA, S. P. A Abordagem Territorial no Planejamento de Políticas Públicas e os Desafios para Uma Nova Relação entre Estado e Sociedade no Brasil. Cadernos Gestão Pública e Cidadania, [S.1.], v. 17, n. 60, jan. 2012. ISSN 2236-5710. Disponível em: $<$ http://bibliotecadigital.fgv.br/ojs/index.php/cgpc/article/view/4043/2731>. Acesso em: 03 Nov. 2016.

A Abordagem territorial no planejamento de políticas públicas e os desafios para uma nova relação entre Estado e sociedade no Brasil. In: IPEA. Instituto de Pesquisa Econômica Aplicada. Brasil em desenvolvimento 2013: estado, planejamento e políticas públicas - Vol. 1. Editores: Rogério Boueri, Marco Aurélio Costa. Brasília: Ipea, 2013.

SILVA JR., Joaquim Alves da. Políticas de desenvolvimento territorial no Brasil: o caso do Vale do Ribeira (SP). Rev. Adm. Pública, Rio de Janeiro , v. 50, n. 3, p. 513527, June 2016 Disponível em: $<$ http://www.scielo.br/scielo.php?script=sci_arttext\&pid=S0034$76122016000300513 \& \operatorname{lng}=$ en\&nrm $=$ iso $>$.

SMA - Secretaria de Meio Ambiente (SP). Resolução SMA 121, de 20 de dezembro de 2013. Define, no âmbito da administração das unidades de conservação do Sistema Estadual de Administração da Qualidade Ambiental, Proteção, Controle e Desenvolvimento do Meio Ambiente e Uso Adequado dos Recursos Naturais - SEAQUA, critérios técnicos e diretrizes que deverão nortear o estabelecimento do zoneamento e da normatização da Área de Proteção Ambiental, de que trata o artigo 15, da Lei Federal $n^{\circ}$ 9.985, de 18 de julho de 2000, e dá providências correlatas. Disponível em: $<$ http://www.ambiente.sp.gov.br/legislacao/resolucoes-sma/resolucao-sma-121-2013/> . Prédio 6 da SMA/CETESB.Ata da $315^{\text {a Reunião }}$ Ordinária do Plenário do Conselho Estadual do Meio Ambiente-CONSEMA, realizada no dia 28 de janeiro de 2014. p. 1-14. . Resolução SMA no 14 , de 04 de fevereiro de 2016. Dispõe sobre a criação de Grupo de Trabalho responsável pela coordenação e o desenvolvimento de atividades relativas à formulação do Zoneamento Ecológico Econômico 
do Estado de São Paulo. Disponível em:

$<$ http://www.ambiente.sp.gov.br/legislacao/resolucoes-sma/resolucao-sma-14-2016/>

Zoneamento Ecológico-Econômico. São Paulo:

2016. Disponível em: http://www.ambiente.sp.gov.br/cpla/zoneamento/zoneamentoecologico-economico/

. Quem somos: o Sistema. Disponível em:

$<$ http://www.ambiente.sp.gov.br/o-sistema/ >. Acesso em: 20/03/2018a

- $368^{\mathrm{a}}$ Reunião Ordinária do Plenário do

CONSEMA: Balanço do Projeto ZEE-SP. São Paulo, 2018b. Disponível em: $<$ http://arquivos.ambiente.sp.gov.br/consema/2018/07/balanco-projeto-zee-do-estado-desao-paulo.pdf $>$

SOJA, E. W. Geografias pós-modernas: a reafirmação do espaço na teoria social crítica. 2 ed. Tradução Vera Ribeiro. Revisão técnica Bertha Becker, Lia Machado. Rio de Janeiro, Zahar. 1993. 324 p.

SOSMA. Fundação SOS Mata Atlântica. Observando os Rios 2017: O retrato da qualidade da água e a evolução dos indicadores de impacto do Projeto Tietê. Disponível em: $\quad<$ https://www.sosma.org.br/wp-content/uploads/2016/06/SOSMA_Observando-osRios-2017_TIETE_online.pdf>

SOUZA, Celina. Políticas públicas: uma revisão da literatura. Sociologias, Porto Alegre, n. 16, p. 20-45, dez. $2006 . \quad$ Disponível em $<$ http://www.scielo.br/scielo.php?script=sci_arttext\&pid=S1517$45222006000200003 \& \operatorname{lng}=$ pt\&nrm=iso $>$.

STEFANI, C. R. B. O sistema ferroviário paulista: um estudo sobre a evolução do transporte de passageiros sobre trilhos. 2007. Dissertação (Mestrado em Geografia Humana) - Faculdade de Filosofia, Letras e Ciências Humanas, Universidade de São Paulo, São Paulo, 2007. 
STEINBERGER. M. Território, ambiente e políticas públicas espaciais. In: - Território, ambiente e políticas públicas espaciais. Brasília: Paralelo 15 e LGE Editora, 2006. P.29-82.

STEINER, C.; RUCKERT, A. A. Análise preliminar das Políticas e Leis Ambientais e Urbanísticas e suas repercussões sobre áreas protegidas urbanas. Revista Geonorte, v. 7, p. 391-404, 2013.

STM. Secretaria dos Transportes Metropolitanos. Plano Integrado de Transportes Urbanos para 2020. São Paulo: STM, 1999. Disponível em : $<$ http://www.stm.sp.gov.br/Pitu2020/Apresentacao $>$

SVMA. Secretaria do Verde e Meio Ambiente. Ata da $143^{a}$ reunião plenária ordinária. Diário Oficial da Cidade de São Paulo, São Paulo, 25 de out. 2012. p. 18-22.

TAVARES , B ; MACEDO, F. Justiça manda suspender Expresso Aeroporto e trem de Guarulhos. O Estado de São Paulo, São Paulo, 29 de jul. 2009. Disponível em : < https://brasil.estadao.com.br/noticias/geral,justica-manda-suspender-expresso-aeroporto-etrem-de-guarulhos,410015>

TORRE, A et al.. Conflits et tensions autour des usages de l'espace dans les territoires ruraux et périurbains. Le cas de six zones géographiques françaises, Revue d'Économie Régionale \& Urbaine 3/2006 (août), p. 415-453. Disponível em :<www.cairn.info/revue-d-economieregionale-et-urbaine-2006-3-page-415.htm>.

TUCCI, C. E. M. Drenagem urbana. Cienc. Cult., São Paulo, v. 55, n. 4, p. 36-37, Dec. 2003 . Disponível em: $<$ http://cienciaecultura.bvs.br/scielo.php?script=sci_arttext\&pid=S0009$67252003000400020 \& \operatorname{lng}=\mathrm{en} \& \mathrm{nrm}=\mathrm{iso}>$ . Controle de enchentes. In : TUCCI, C. E. M. (org.) Hidrologia: ciência e aplicação. 4 ed. Porto Alegre : Editora UFRGS/ABRH, 2007. P. 621-652. 
. Águas urbanas. Estud. av., São Paulo, v. 22, n. 63, p. 97-112, 2008.

Available from $\quad<$ http://www.scielo.br/scielo.php?script=sci_arttext\&pid=S0103$40142008000200007 \& \operatorname{lng}=$ en \&nrm=iso $>$

TUFFANI, M. Secretário-adjunto de Alckmin tentou forjar declarações de pesquisadores.

$\begin{array}{llll}\text { Direto da } & \text { Ciência. } & \text { Disponível }\end{array}$ em $:<$ http://www.diretodaciencia.com/2017/06/02/secretario-adjunto-de-alckmin-tentouforjar-declaracoes-de-pesquisadores/ >

Alckmin troca direção da Fundação Florestal pela sexta vez em três anos.

Direto da Ciência. Disponível em $:<$ http://www.diretodaciencia.com/2018/03/12/alckmintroca-direcao-da-fundacao-florestal-pela-sexta-vez-em-tres-anos/ > .

VIDAL DE LA BLACHE, Paul. Princípios de Geografia Humana. Lisboa: Edições Cosmos, 1954, $2^{\mathrm{a}}$ edição, 393p.

ZANIRATO, S. H. História da ocupação e das intervenções na várzea do rio Tietê. Revista Crítica Histórica, v. 4, p. 117-129, 2011. 